\title{
Effect of Natural Compounds on Insulin Signaling
}

\author{
Paolo Paoli ${ }^{*}, \#$, Anna Caselli, Guido Camici and Paolo Cirri \\ ${ }^{I}$ Dipartimento di Scienze Biomediche Sperimentali e Cliniche "Mario Serio", Università degli Studi di \\ Firenze, Firenze, Italy; ${ }^{2}$ Center for Research, Transfer and High Education DenoTHE, Firenze, Italia
}

\begin{abstract}
Results of several epidemiological studies have indicated that diabetes mellitus will become a global epidemic in the next decades, being more than 400 million the human subjects in the world affected by this disease in the 2030. Most of these subjects will be affected by type 2 diabetes mellitus (T2DM) whose diffusion is mainly related to excessive caloric upload, sedentary life and obesity. Typically, the treatment for T2DM is diet, weight control, physical activity or hypoglycaemic and/or lipid-lowering drugs. Unfortunately, these drugs often show low effectiveness or adverse side effects, thereby forcing patient to discontinue medical treatment. Nevertheless traditional medicine suggests the use of several formulations or medicinal foods to treat T2DM. Most of them are characterized by safety, low cost, effectiveness, and good availability. Before the advent of modern pharmacology, these remedies were used to treat diabetes and obesity or prevent their onset. Today, we know that their effectiveness is due to the presence of several bioactive compounds able to influence insulin signaling pathway and cellular metabolism. In the last decades, many efforts have been carried out to clarify their action mechanism. Here we provide a classification of the natural compounds that stimulate the insulin pathway, highlighting their effectiveness in controlling glycaemia on diabetic animal models or improving insulin signaling in cellular systems.
\end{abstract}

Keywords: AMPK, insulin signaling, natural compounds, PPAR, PTP1B inhibitors, type 2 diabetes.

\#Author's Profile: Paolo Paoli is a Biologist, specialized in Biochemistry and Clinical Chemistry and also a PhD in Biochemistry in 2002. Currently, he is a researcher at the Dipartimento di Scienze Biomediche Sperimentali e Cliniche "Mario Serio", University of Florence. His research fields are enzymology, drug discovery, and cancer cells metabolism.

\section{INTRODUCTION}

Insulin signaling is mediated by a complex and highly integrated network that controls many physiological processes [1]. Insulin receptor (IR), a tetrameric membrane protein consisting of two extracellular $\alpha$-subunits and two intracellular $\beta$-subunits, is an allosteric enzyme in which the $\alpha$ subunits inhibit the intrinsic tyrosine kinase activity of the $\beta$ subunits. Insulin binding to the $\alpha$-subunit enhances IR kinase activity thus triggering downstream signaling events such as insulin receptor substrates (IRSs) recruitment and phosphorylation. Tyr-phosphorylated IRS acts as a docking protein for intracellular adaptor proteins (e.g. the regulatory subunit of PI3K, and Grb2) which activate two main signaling pathways: i) the PI3K-AKT/PKB pathway, which is responsible for most of the metabolic actions of insulin (stimulation of glucose uptake; glycogen, lipids and protein synthesis; inhibition of lipolysis, glycogenolysis and gluconeogenesis ; ii) the Ras-MAPK pathway, which regulates the expression of some genes and cooperates with the PI3K pathway to control cell growth and differentiation [1] (Fig. 1).

In 2010285 million people worldwide was affected by diabetes and this number is estimated to about 400 million in 2030 [2]. About $95 \%$ of diabetic patients suffer from Type 2 Diabetes Mellitus (T2DM), a form characterized by a defective insulin signaling in adipose tissue, liver and muscle cells. Although the molecular mechanisms leading to the

*Address correspondence to this author at the Dipartimento di Scienze Biomediche Sperimentali e Cliniche "Mario Serio", Università degli Studi di Firenze, Firenze, Italy; Tel: +390552751248; Fax: +390552751201;

E-mail: paolo.paoli@unifi.it development of T2DM should be still clarified, this phenomenon has been summarized with the term insulin resistance. Genetic background, aging, sedentary, and mostly, high caloric uptake and excessive lipids accumulation, are considered the main causes favoring the onset of insulin resistance. This is confirmed also by the results of several epidemiological analysis that revealed a strict correlation between insulin resistance and obesity [3-5]. Therapeutic treatment of T2DM includes the administration of secretagogues (sulfonylureas) that stimulate insulin release from pancreas, $\alpha$-glucosidase inhibitor (acarbose) which reduces glucose absorption, biguanides (metformin) and thiazolidinediones (pioglitazone and rosiglitazone) that contribute to reduction of fatty acid deposits and improve insulin sensitivity. Nevertheless, all available therapies have limited effects and most of the drugs used trigger unexpected side effects, forcing patients to discontinue the treatment [6]. The lack of effectiveness of current drugs in treating T2DM, the high social impact of diabetes as well as the high cost of pharmaceutical treatments determine the need to develop new therapeutic approaches to prevent the onset and the progression of this disease. In the last decades, an increasing number of studies revealed that many natural substances extracted from different organisms (plants, animals, fungi, lichens, sponges, chorals, and bacteria) modulate the IR signaling, thereby acting on carbohydrates and/or lipids metabolism [7, 8]. Interestingly, it has been demonstrated that also common fruits and vegetables contain several biologically active components (including polyphenols) able to influence energetic metabolism and glucose homeostasis, without adverse effects. Many scientists suggest that these compounds could be used as new drugs to treat T2DM or, 


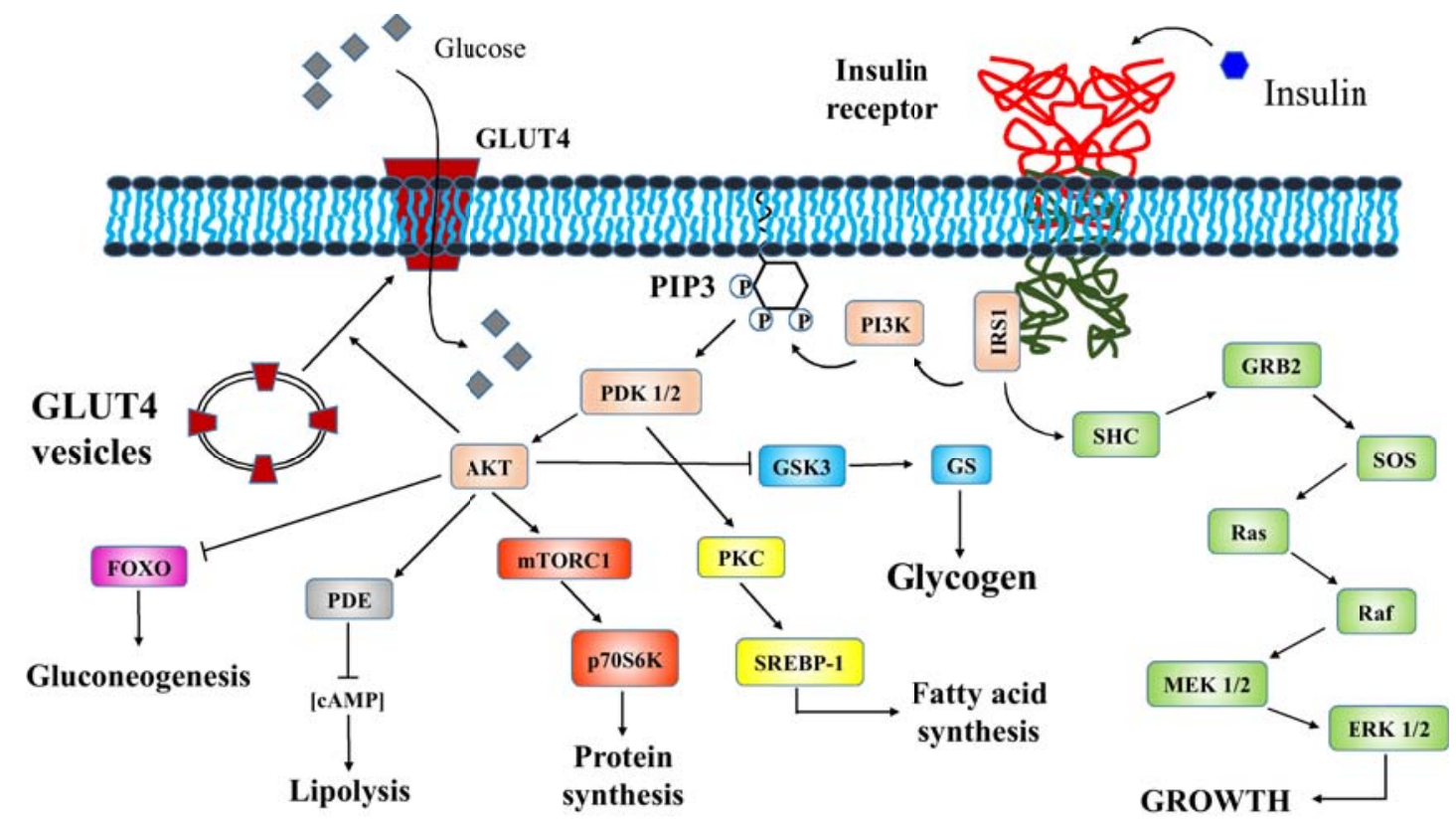

Fig. (1). The main pathways of insulin signaling. For acronyms see 'Abbreviations'.

alternatively, could represent scaffold molecules to obtain new and more specific antidiabetic drugs $[9,10]$. Dietary polyphenols may be useful for supplementary treatments in T2DM and its cardiometabolic complications [11-13] inhibiting $\alpha$-amylase and $\alpha$-glucosidase in the intestinal lumen, thus reducing the absorption of simple sugars [14-16]. Furthermore, some polyphenols may improve glucose uptake in muscle and in adipocytes, inhibit gluconeogenesis and promote the storage of glycogen in the liver. However, the usage of these dietary polyphenols as drugs should take into account the effects that T2DM may have on their pharmacokinetics. Accordingly, an in-depth understanding of diabetes-associated changes in polyphenols absorption, distribution, metabolism, elimination and bioactivity is needed [17]. In this work we review the natural compounds so far described to influence the insulin signaling pathway, highlighting their mechanism of action and their efficacy both in vitro and in vivo models.

\section{TYPICAL NATURAL COMPOUNDS THAT MAY AF- FECT INSULIN SIGNALING}

Several human foods such as tea, coffee, wine, cereal grains, vegetables, legumes, and fruits contain natural polyphenols; that are considered very important for human health. Among the 8000 phenolic compounds currently known, about half have flavonoid structures. Flavonoids (aglycones and their glycosylated derivatives) are the most important plant pigments. The basic structure of flavonoid aglycones is characterized by a C15 skeleton (Scheme 1) having a C6-C3-C6 carbon framework which contains a 1benzopyran (chromene) ring system, in which the aromatic ring is defined as ring A and the pyran as ring $\mathrm{C}$. Another C6 aromatic ring (B) is linked to the pyran moiety of the chromene ring. Flavonoids are further divided into the following subclasses, which differ for oxidation state and connection modality of ring $\mathrm{B}$ to the position 2 or 3 of the heterocyclic C-ring: flavanones, flavanols, flavones, flavonols and isoflavones. Anthocyanidins, and chalchones which contain a 2-phenyl-1-benzopyrazolium, are therefore included in the flavonoid class. Chalcones, which lack the C-ring, are early intermediates in the biosynthesis of flavonoids in which the pyran ring $\mathrm{C}$ has not yet been formed. Some chemical structure of typical flavonoids are shown in Scheme 1. The chemical structures of other typical compounds are shown in Schemes 2-5.

\section{Natural Compounds that Directly Interact and Activate Insulin Receptor}

Only few natural compounds, such as demethylasterriquinone B1 (also known as L-783,281), 1,2,3,4,6-penta-Ogalloyl- $\beta$-D-glucopyranose, and $\alpha$-lipoic acid, directly act on IR, mimicking insulin effects (Fig. 2) [18-20].

Demethylasterriquinone B1 is a metabolite of the fungus species Pseudomassaria sp. that interacts with intracellular IR $\beta$-subunit stimulating its tyrosine kinase activity determinig increased glucose uptake. The action of this compound is selective and does not induce insulin-like proliferative effects. Oral subministration of demethylasterriquinone B1 to animal models decreases blood glucose level without inducing hypoglycaemia, both in streptozotocininduced diabetic mice and in lean non-diabetic mice. This finding suggests that this compound is able to stimulate IR activity or to act as insulin sensitizer, thereby decreasing the amount of hormone need to obtain a physiological response $[21,22]$.

The 1,2,3,4,6-penta-O-galloyl-beta-D-glucopyranose is an ester of gallic acid with glucose, purified from Lagerstroemia speciosa. This compound interacts with the IR $\alpha$ subunit in a binding site different from that of insulin, inducing a direct IR activation and enhancing glucose transport. The 1,2,3,4,6-penta-O-galloyl-beta-D-glucopyranose elicits an insulin-mimetic action in diabetic and obese mice reducing both blood glucose and insulin levels, with no significant 
<smiles>[R]Cc1cc(-c2cc(=O)c3c([R])cc([R])c([R3])c3o2)cc([R3])c1[R]</smiles><smiles>[R]c1cc([R])c2c(c1)OC(c1cc([R3])c([R3])c([R3])c1)C(O)C2=O</smiles><smiles>[R]c1cc([R])c2c(=O)cc(-c3cc([R3])c([R3])c([R3])c3)oc2c1</smiles><smiles>[R]c1cc([R])c2c(=O)c(O)c(-c3cc([R3])c([R4])c([R5])c3[R])oc2c1</smiles><smiles></smiles><smiles>[R]c1cc([R])c2cc(C(=O)/C=C/c3cc([R])c([R3])c([R3])c3)c(-c3cc([R3])c([R])c([R6])c3)[o+]c2c1</smiles>

\begin{tabular}{|c|c|c|c|}
\hline $\begin{array}{c}\text { Flavanone } \\
\left(\mathrm{R}_{1}, \mathrm{OH} ; \mathrm{R}_{2}, \mathrm{OH}\right)\end{array}$ & $\mathrm{R}_{3}$ & $\mathrm{R}_{4}$ & $\mathrm{R}_{5}$ \\
\hline Narigenin & $\mathrm{HH}$ & $\mathrm{OH}$ & $\mathrm{HH}$ \\
\hline Sigmoidin $\mathrm{B}$ & $\mathrm{OH}$ & $\mathrm{OH}$ & $-\mathrm{CH}_{2}-\mathrm{CH}=\mathrm{CMe}_{2}$ \\
\hline Hesperetin & $\mathrm{HH}$ & $\mathrm{OMe}$ & $\mathrm{OH}$ \\
\hline
\end{tabular}

\begin{tabular}{|c|c|c|c|}
\hline $\begin{array}{c}\text { Flavanol } \\
\left(\mathrm{R}_{1}, \mathrm{OH} ; \mathrm{R}_{2}, \mathrm{OH}\right)\end{array}$ & $\mathrm{R}_{3}$ & $\mathrm{R}_{4}$ & $\mathrm{R}_{5}$ \\
\hline Catechin & $\mathrm{OH}$ & $\mathrm{OH}$ & $\mathrm{HH}$ \\
\hline Epigallocatechin & $\mathrm{OH}$ & $\mathrm{OH}$ & $\mathrm{OH}$ \\
\hline
\end{tabular}

\begin{tabular}{|c|c|c|c|}
\hline $\begin{array}{c}\text { Flavone } \\
\left(\mathrm{R}_{1}, \mathrm{OH} ; \mathrm{R}_{2}, \mathrm{OH}\right)\end{array}$ & $\mathrm{R}_{3}$ & $\mathrm{R}_{4}$ & $\mathrm{R}_{5}$ \\
\hline Luteolin & $\mathrm{HH}$ & $\mathrm{OH}$ & $\mathrm{OH}$ \\
\hline Apigenin & $\mathrm{HH}$ & $\mathrm{OH}$ & $\mathrm{HH}$ \\
\hline
\end{tabular}

\begin{tabular}{|c|c|c|c|c|}
\hline $\begin{array}{c}\text { Flavonol } \\
\left(\mathrm{R}_{1}, \mathrm{OH} ; \mathrm{R}_{2}, \mathrm{OH}\right)\end{array}$ & $\mathrm{R}_{3}$ & $\mathrm{R}_{4}$ & $\mathrm{R}_{5}$ & $\mathrm{R}_{6}$ \\
\hline Quercetin & $\mathrm{OH}$ & $\mathrm{OH}$ & $\mathrm{HH}$ & $\mathrm{HH}$ \\
\hline Kaempferol & $\mathrm{HH}$ & $\mathrm{OH}$ & $\mathrm{HH}$ & $\mathrm{HH}$ \\
\hline Myricetin & $\mathrm{OH}$ & $\mathrm{OH}$ & $\mathrm{OH}$ & $\mathrm{HH}$ \\
\hline Morin & $\mathrm{HH}$ & $\mathrm{OH}$ & $\mathrm{HH}$ & $\mathrm{OH}$ \\
\hline
\end{tabular}

Isoflavones

(basic chemical structure)

\begin{tabular}{|c|c|c|c|c|}
\hline $\begin{array}{c}\text { Chalcone } \\
\left(\mathrm{R}_{1}, \mathrm{OH} ; \mathrm{R}_{2}, \mathrm{OH}\right)\end{array}$ & $\mathrm{R}$ & $\mathrm{R}_{3}$ & $\mathrm{R}_{4}$ & $\mathrm{R}_{5}$ \\
\hline BroussochalconeA & $-\mathrm{CH}_{2}-\mathrm{CH}=\mathrm{CMe}_{2}$ & $\mathrm{HH}$ & $\mathrm{OH}$ & $\mathrm{OH}$ \\
\hline
\end{tabular}

\begin{tabular}{|c|l|l|l|}
\hline $\begin{array}{c}\text { Anthocyanidin } \\
\left(\mathrm{R}_{1}, \mathrm{OH} ; \mathrm{R}_{2}, \mathrm{OH}\right)\end{array}$ & $\mathrm{R}_{3}$ & $\mathrm{R}_{4}$ & $\mathrm{R}_{5}$ \\
\hline Cyanidin & $\mathrm{OH}$ & $\mathrm{OH}$ & $\mathrm{OH}$ \\
\hline
\end{tabular}

Scheme 1. Chemical structures of the main flavonoid classes, and of typical flavonoids.

changes in body weight, food intake, or physical activity with respect to the control mice [19].

Recently, it has been reported that $\alpha$-lipoic acid interacts with the tyrosine kinase domain of the insulin receptor, leading to its autophophorylation and propagation of insulin signaling. Molecular modeling studies on an $\alpha$-lipoic acid-IR complex suggest that $\alpha$-lipoic acid stabilizes the active form of the IR kinase domain, favoring the ATP binding to the kinase domain and contributing to its auto-activation [20].

\section{Natural Compound Targeting Phosphotyrosine Protein Phosphatase Enzymes}

In physiological conditions insulin signaling is tightly regulated by several mechanisms: i) dephosphorylation of phospho-tyrosine residues of IR and/or IRS proteins by specific protein tyrosine phosphatases (PTPs); ii) serine phosphorylation of IRS proteins by various Ser/Thr kinases; iii) binding of inhibitory proteins; iv) ligand-induced degradation [1]. It has been demonstrated that hundreds of natural 
<smiles>CC(C)=CCc1c(O)ccc2c1O/C(=C\c1ccc(O)c(O)c1)C2=O</smiles>

1<smiles>CC1=Cc2oc3cc(O)c(O)c(C(=O)O)c3c(=O)c2CO1</smiles>

2<smiles>C=C[C@](C)(/C=C/c1ccc(O)cc1)CCC=C(C)C</smiles>

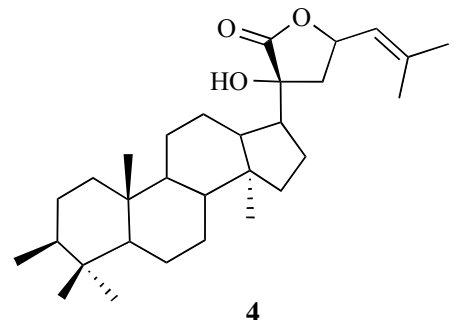<smiles>COc1cc(C[C@H](C)[C@@H](C)Cc2ccc(O)c(OC)c2)ccc1O</smiles><smiles>O=c1[nH]c2ccccc2c(-c2cccc(O)c2)c1O</smiles>

Scheme 2. Competitive inhibitors of PTP1B. Chemical structures: 1, Licoagroaurone; 2, Anhydrofulvic acid; 3, Bakuchiol; 4, (20S)$3 \beta, 20,23 \xi$-Trihydroxydammarane-24-en-21-oic acid-21, 23 lactone; 5, meso-Dihydroguaiaretic acid; 6, Viridicatol.

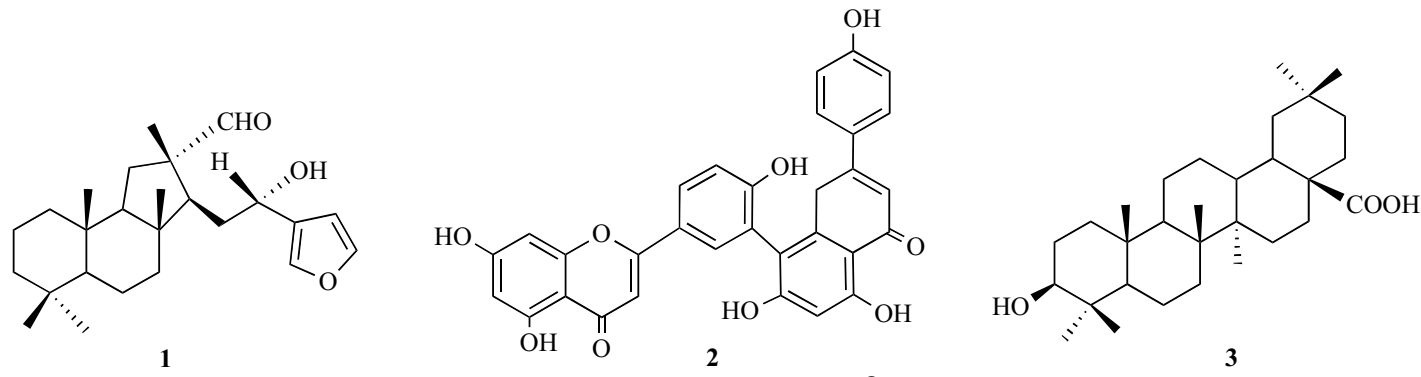<smiles>CC(C)[C@@H]1CCCC(CC[C@H]2C(OS(=O)(=O)O)CCC3[C@H](C[C@@H]2O)[C@@]2(C)C[C@H](NCCCNCCCCNCCCN)CC[C@@]32C)O1</smiles><smiles>CC(C)=CCc1cc2c(cc1O)oc(=O)c1cc(O)ccc12</smiles><smiles></smiles><smiles>C=C1[C@H](O)[C@@H](O)C[C@]2(C)C3CCC4C([C@@H](C)CC[C@@]4(C)C(=O)O)[C@@]3(C)CC[C@@]12C</smiles><smiles></smiles>

Scheme 3. Non competitive inhibitors of PTP1B. Chemical structures: 1, Hyrtiosal; 2, Amentoflavone; 3, Morolic acid; 4, Trodusquemine; 5, Psoralidin; 6, Fructigenine A; 7, Ilekudinol B; 8, 16 $\alpha \mathrm{H}, 17$-isovaleryloxy-ent-kauran-19-oic acid.

substances stimulate insulin signaling acting as inhibitors of protein tyrosine phosphatases (Fig. 2), alleviating insulin resistance [23], for example: PTP1B [24], LAR (leukocyte common antigen-related PTP) [25-29], PTP $\alpha$ [30-34], SHP-2 [35-42], TC-PTP [43, 44], PTPE [30, 45], LMW-PTP [46, 47]; PTP-MEG2 [48].

PTP1B is one of the most important negative regulator of IR signaling in liver and muscle [49-52]. Hepatic PTP1B expression is increased in T2DM rat models [53], while mice lacking PTP1B show improved insulin sensitivity with enhanced phosphorylation of hepatic insulin receptor and IRS1 [54]. PTP1B contains an active site loop (P-loop) where the phosphate group of the substrate interacts with Arg221 and with other P-loop residues, including the catalytic Cys215 residue. The crystal structure of PTP1B-ligand complexes revealed another phosphotyrosine binding site (site B), 


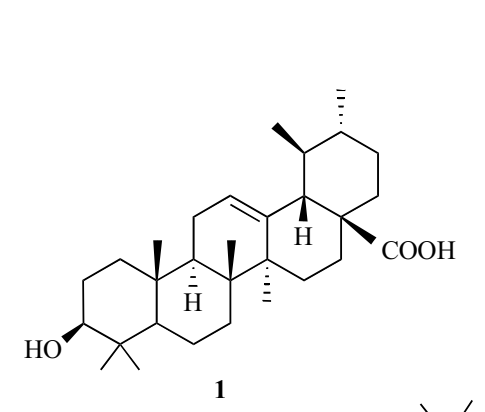<smiles>CC1C2CCC34CC(=CCC3C2(C)CC[C@H]1O)C1CCC2(C(=O)O)CCC(C)(C)CC2CC14</smiles><smiles></smiles><smiles>CC(C)=CCc1c(O)ccc(C(=O)/C=C/c2ccc(O)cc2)c1O</smiles><smiles>CC(C)=CCc1cc(C(=O)C2(C(=O)c3cc(CC=C(C)C)c(O)cc3/C=C3\Oc4c(ccc(O)c4CC=C(C)C)C3=O)Oc3cc(O)c(CC=C(C)C)cc3C2=O)ccc1O</smiles>

HO<smiles>CC(C)=CCc1cc(-c2coc3cccc(O)c3c2=O)cc(O)c1O</smiles>

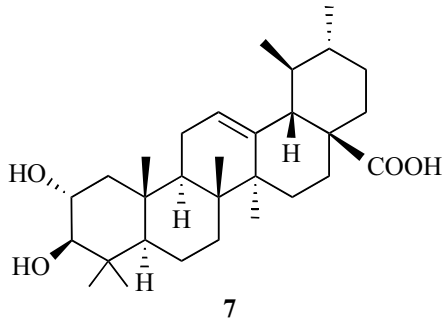<smiles>C=C[C@]1(C)C=C2CC[C@H]3[C@H](CCC[C@]3(C)C(=O)O)[C@@H]2CC1</smiles>

Scheme 4. Mixed type inhibitors of PTP1B. Chemical structures: 1, Ursolic acid; 2, Mulberrofuran G; 3, Licoagrone; 4, Oleanoic acid; 5 , Isobavachalcone; 6, Glisoflavone; 7, Corosolic acid; 8, ent-pimara-8(14),15-diene-19-oic acid.

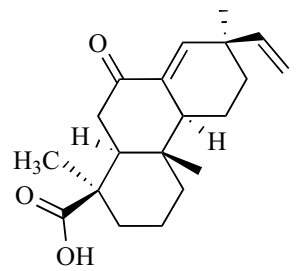

1

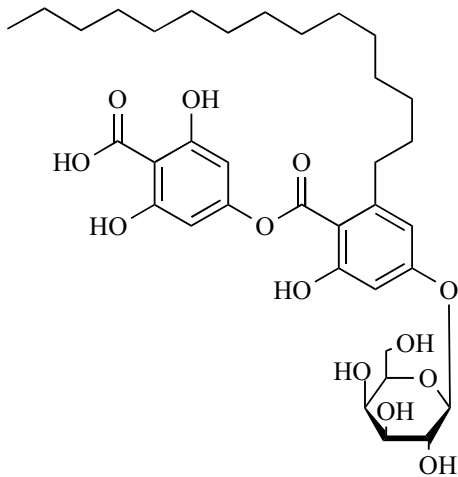

2

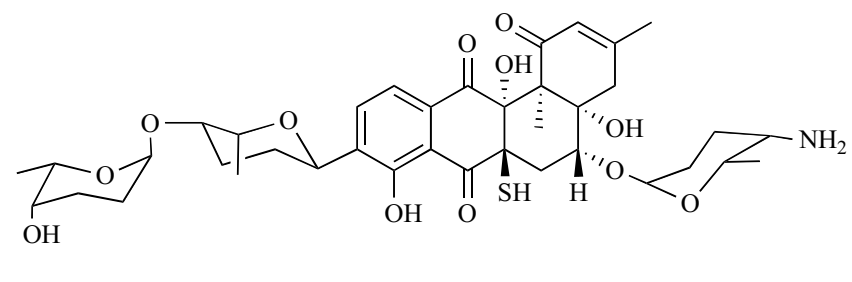

3

Scheme 5. The most potent natural inhibitors of PTP1B. Chemical structures: 1, 7-Oxo-ent-pimara-acid; 2, Aquastatin A; 3, Grecocycline B.

close to the conserved primary active site (site A), which contains Met258, Gly259, Gln262, Gln266, Arg24, and Arg254 [55]. While competitive inhibitors bind to site A, most non competitive and mixed type inhibitors bind to site B blocking the catalytic process. Several compounds listed in Table 1 have been characterised for their inhibition mechanisms (see below).

\section{Natural PTP1B Inhibitors}

In a detailed review Jiang et al. [56] described about 300 natural or synthetic products acting as PTP1B inhibitors. Tables 1 provides an updated overview of natural substances exhibiting PTP1B inhibitory activity on, their $\mathrm{IC}_{50}$ values and the natural resources from which they were isolated. Most of them have flavonoid or terpenoid structures. About $15 \%$ of flavonoids and almost half of terpenoids listed in Tables $\mathbf{1 A}$ and $\mathbf{1 B}$, are inhibitors of PTP1B with $\mathrm{IC}_{50}$ values in the 2-10 $\mu \mathrm{M}$ range. Furthermore, also more than $60 \%$ of phenolic compounds listed in Table 1C, and about $40 \%$ of compounds listed in Table 1D are potent inhibitors of PTP1B, with $\mathrm{IC}_{50}$ values in the low $\mu \mathrm{M}$ range. About $44 \%$ of compounds act as a non competitive inhibitors, $34 \%$ as mixed-type inhibitors and $22 \%$ are competitive inhibitors respect to PTP1B (see Scheme 2-4). The compounds 7-Oxoent-pimara-acid, a diterpenoid extracted from Aralia continentalis $\left(\mathrm{IC}_{50}\right.$ value $\left.=0.09 \mu \mathrm{M}\right)$ [57], aquastatin $\mathrm{A}$, a $\beta$ galactopyranoside extracted from a Cosmospora species 


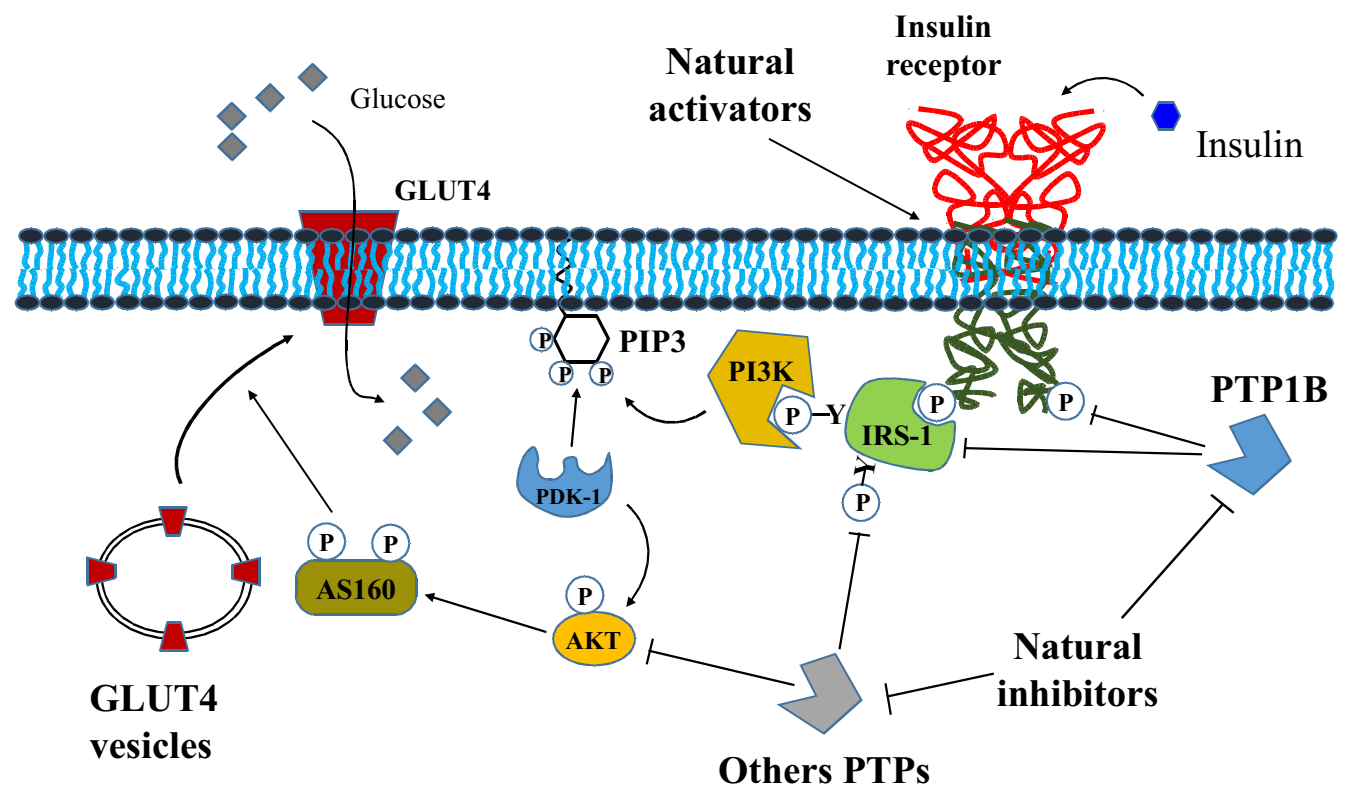

Fig. (2). Inhibition of PTPs by natural compounds improves insulin signaling. Insulin activates the IR tyrosine kinase that phosphorylates and recruits different substrate adaptors such as the IRS proteins which, in turn, recruit and activate other effectors contributing to signal propagation. Most proteins involved in insulin signaling are regulated by reversible phosphorylation on tyrosine and/or serine/threonine residues. A number of PTPs act as negative regulators of insulin signaling. One of the most important PTPs involved in the regulation of insulin receptor activity is PTP1B, which strongly contributes to downregulation of insulin signaling by dephosphorylating IR and IRS-1. Several natural molecules are able to inhibit PTP1B as well as other PTPs, thereby increasing insulin sensitivity. For an explanation of acronyms see 'Abbreviations'.

$\left(\mathrm{IC}_{50}\right.$ value $\left.=0.19 \mu \mathrm{M}\right)[58]$, and Grecocycline $\mathrm{B}$, a benzanthracene quinone extracted from a Streptomyces species $\left(\mathrm{IC}_{50}\right.$ value $\left.=0.52 \mu \mathrm{M}\right)[59]$ (Table 1D) are the most potent natural inhibitors of PTP1B (Scheme 5). The majority of the compounds analyzed behaves as non competitive and mixedtype inhibitors. The non competitive inhibitors bind to the enzyme at a specific site usually near the active site, distorting the catalytic residues geometry and position. Mixed-type inhibitors act similarly, but they also hinder the binding of substrate. In silico docking indicated that morin, a non competitive inhibitor of PTP1B, establishes hydrogen bonds with residues near to the active site, such as Arg254, Gln262, Asp29, Met258 and Gly259 (site B), impairing the ability of the enzyme to hydrolyze substrate phosphoesteric bond [60]. Docking simulation indicated that site $B$ residues are involved in the binding of ursolic acid, a triterpene contained in traditional Chinese medicinal herbs. Ursolic acid, due to its different steric hindrance and positioning with respect to morin, interacts also with residues at the boundary between a site A and site B, thereby influencing substrate binding [61] and behaves as a mixed-type inhibitor. Undoubtedly the ability of ursolic acid to form additional bonds with respect to morin, can explain its greater binding affinity. The diterpenoid 7-oxo-ent-pimara-8(14),15-diene-19-oic acid, acts as a non competitive inhibitor. Nevertheless, it does not interact with site B, but with the catalytic WDP loop; this stabilizes the open form of the active site, thereby blocking the catalytic process [62]. Few compounds listed in Tables 1A-D were tested also on other PTPs. For example ascochitine $\left(\mathrm{IC}_{50}\right.$ value $=38.5 \mu \mathrm{M}$ on PTP1B $)$, extracted from Ascochyta salicorniae, is a less potent inhibitor of PTP1B than of $M$. tuberculosis $\mathrm{MPtpB}\left(\mathrm{IC}_{50}\right.$ value $\left.=11.5 \mu \mathrm{M}\right)$ [63]. Dihydrocarolic acid $\left(\mathrm{IC}_{50}\right.$ value $=38 \mu \mathrm{g} / \mathrm{ml}$ on PTP1B $)$ and Penitricin
$\mathrm{D}\left(\mathrm{IC}_{50}\right.$ value $=15.8 \mu \mathrm{g} / \mathrm{ml}$ on PTP1B $)$, both extracted from Aspergillus niger, are less potent inhibitors versus PTP1B than versus the $\mathrm{CD} 45\left(\mathrm{IC}_{50}\right.$ values $=1.2$ and $2.3 \mu \mathrm{g} / \mathrm{ml}$, respectively) [64]. Aquastatin $\mathrm{A}$ ( $\mathrm{IC}_{50}$ value $=0.19 \mu \mathrm{M}$ on PTP1B), extracted from a fungus of the Cosmospora species, inhibits also TC-PTP, another enzyme involved in negative regulation of insulin-mediated signaling [58]; TC-PTP is an enzyme highly homologous with PTP1B, displaying $72 \%$ sequence identity. The compound 7-hydroxy-5,6-dimethoxy1,4-phenantrene quinone $\left(\mathrm{IC}_{50}\right.$ value $=38 \mu \mathrm{M}$ on PTP1B $)$, which is a metabolite extracted from Dendrobium moniliforme, is ten-fold more potent inhibitor against the dual specificity VHR PTP than against PTP1B [65]. Corosolic acid, a compound contained in several Chinese medicinal herbs, inhibits in vitro several diabetes-related non-receptor PTPs [66], such as PTP1B $\left(\mathrm{IC}_{50}\right.$ value $\left.=5.49 \mu \mathrm{M}\right)$, TC-PTP $\left(\mathrm{IC}_{50}\right.$ value $\left.=11.31 \mu \mathrm{M}\right)$, SHP1 $\left(\mathrm{IC}_{50}\right.$ value $\left.=24.56 \mu \mathrm{M}\right)$ and SHP2 $\left(\mathrm{IC}_{50}\right.$ value $\left.=10.50 \mu \mathrm{M}\right)$. Shi et al. [66] reported that corosolic acid is able to stimulate glucose uptake in cultured L6 myotubes. Furthermore, experiments performed with GLUT4 transfected $\mathrm{CHO} / \mathrm{hIR}$ cells showed that corosolic acid increases GLUT4 translocation from cytoplasm to the cell membrane [66]. Both actions were blocked by wortmannin, a specific inhibitor of PI3K, a key downstream enzyme of insulin pathway. In addition, corosolic acid induces insulin receptor and Akt-Ser phosphorylation in cultured $\mathrm{CHO} / \mathrm{hIR}$ cells, but it is unable to enhance AMPK phosphorylation. These authors suggest that corosolic acid might increase glucose uptake and GLUT4 translocation enhancing insulin receptor phosphorylation via the inhibition of certain PTPs that antagonize IR signaling. Ursolic acid inhibits in vitro some diabetes-related non-receptor PTPs such as: i) PTP1B (various $\mathrm{IC}_{50}$ values for PTP1B were reported: 
Table 1A. Natural inhibitors of PTP1B.

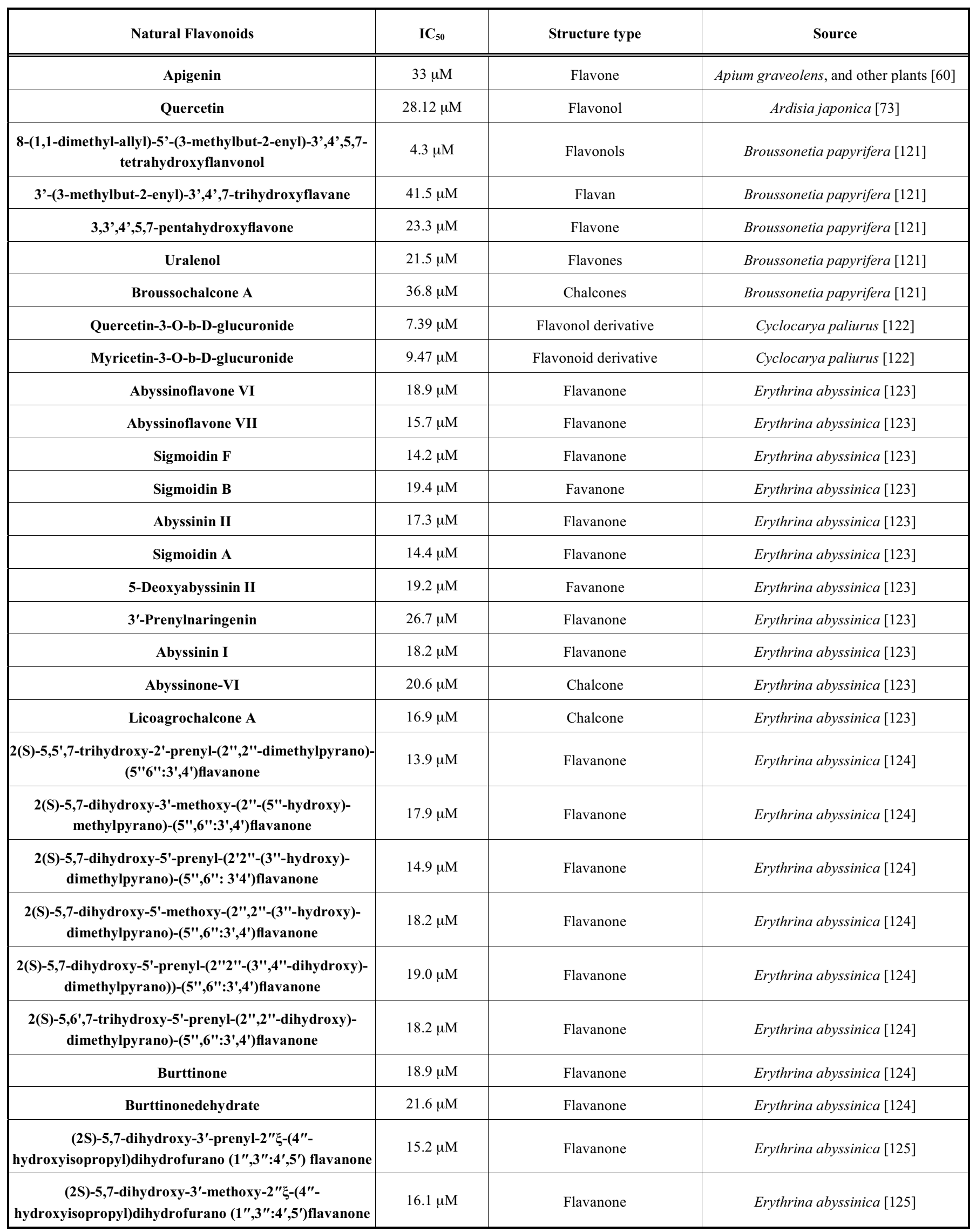


(Table 1A) contd....

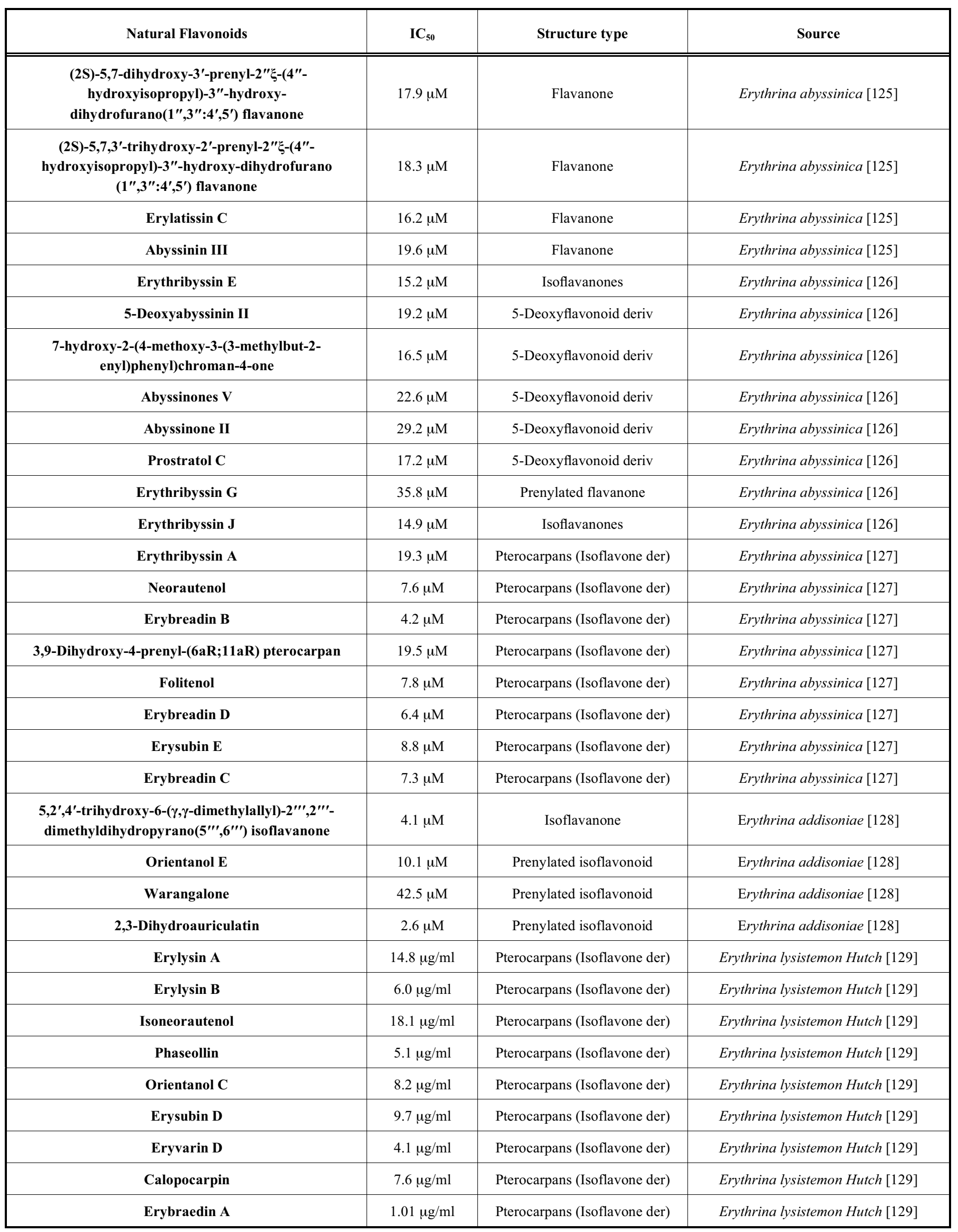


(Table 1A) contd...

\begin{tabular}{|c|c|c|c|}
\hline Natural Flavonoids & $\mathrm{IC}_{50}$ & Structure type & Source \\
\hline Abyssinone-V-4'-O-methyl ether & $26.3 \mu \mathrm{M}$ & Flavonoid & Erythrina mildbraedii [130] \\
\hline Abyssinone-IV-4'-O-methyl ether & $21.2 \mu \mathrm{M}$ & Isoprenylated Flavonoid & Erythrina mildbraedii [130] \\
\hline Abyssinone-V & $39.7 \mu \mathrm{M}$ & Flavonoid & Erythrina mildbraedii $[130]$ \\
\hline Abyssinone-IV & $16.0 \mu \mathrm{M}$ & Flavonoid & Erythrina mildbraedii [130] \\
\hline Abyssinone-VI-4-O-methyl ether & $14.8 \mu \mathrm{M}$ & Chalcone (isoprenylated Flavonoid & Erythrina mildbraedii $[130]$ \\
\hline Sigmoidin E & $39.2 \mu \mathrm{M}$ & Flavonoid & Erythrina mildbraedii $[130]$ \\
\hline Alpinumisoflavone & $41.5 \mu \mathrm{M}$ & Isoflavone & Erythrina mildbraedii [130] \\
\hline Licoflavanone-4'-O-methyl ether & $29.6 \mu \mathrm{M}$ & flavanone & Erythrina mildbraedii $[131]$ \\
\hline $\begin{array}{l}\text { 2',7-dihydroxy-4'-methoxy-5'-(3-methylbut-2- } \\
\text { enyl)isoflavone }\end{array}$ & $21.3 \mu \mathrm{M}$ & Isoflavone & Erythrina mildbraedii $[131]$ \\
\hline $\begin{array}{l}\text { (3R)-2',7-dihydroxy-3'-(3-methylbut-2-enyl)-2'"',2'"'- } \\
\text { dimethylpyrano(5'",6"' : } 4 \text { ',5')isoflavan }\end{array}$ & $5.5 \mu \mathrm{M}$ & Isoflavan & Erythrina mildbraedii [131] \\
\hline Abyssinin II & $40.5 \mu \mathrm{M}$ & Flavanone & Erythrina mildbraedii $[131]$ \\
\hline Parvisoflavone B & $42.6 \mu \mathrm{M}$ & Isoflavone & Erythrina mildbraedii [131] \\
\hline Licoagrone & $6.0 \mu \mathrm{M}$ & Flavonoid dimer & Glycyrrhiza species [132] \\
\hline Licoagrodin & $11.5 \mu \mathrm{M}$ & Flavonoid dimer & Glycyrrhiza species [132] \\
\hline Licoagroaurone & $23.9 \mu \mathrm{M}$ & Prenylated aurone & Glycyrrhiza species [132] \\
\hline Isobavachalcone & $27.3 \mu \mathrm{M}$ & Prenylated chalcone & Glycyrrhiza species [132] \\
\hline Glisoflavone & $27.9 \mu \mathrm{M}$ & Flavones & Glycyrrhiza uralensis [133] \\
\hline Kuwanon J & $2.7 \mu \mathrm{M}$ & Chalcone derivative & Morus bombycis [134] \\
\hline Kuwanon R & $8.2 \mu \mathrm{M}$ & Chalcone derivative & Morus bombycis [134] \\
\hline Kuwanon V & $13.8 \mu \mathrm{M}$ & Chalcone derivative & Morus bombycis [134] \\
\hline Licochalcone A & $19.1 \mu \mathrm{M}$ & Retrochalcone & Morus bombycis [134] \\
\hline Licochalcone C & $30.9 \mu \mathrm{M}$ & Retrochalcone & Morus bombycis [134] \\
\hline Licochalcone E & $20.7 \mu \mathrm{M}$ & Retrochalcone & Morus bombycis [134] \\
\hline Karanjin & $84.5 \mu \mathrm{M}$ & Flavonoid (benzopyran dervative) & Pongamia pinnata $[85]$ \\
\hline Morin & $15 \mu \mathrm{M}$ & Flavonol & Psidium guajava, and other plants [60] \\
\hline Amentoflavone & $7.3 \mu \mathrm{M}$ & Flavone & Selaginella tamariscina [77] \\
\hline 3',5'-Diprenylgenistein & $31.75 \mu \mathrm{M}$ & Flavonoid (genistein derv) & Tetracera scandens $[78]$ \\
\hline 6,8-Diprenylgenistein & $28.13 \mu \mathrm{M}$ & Flavonoid (genistein derv) & Tetracera scandens [78] \\
\hline Derrone & $20.63 \mu \mathrm{M}$ & Flavonoid (genistein derv) & Tetracera scandens [78] \\
\hline Alpinumisoflavone & $37.52 \mu \mathrm{M}$ & Flavonoid (genistein derv) & Tetracera scandens [78] \\
\hline \multicolumn{4}{|l|}{ OTHER NATURAL BENZOPYRAN DERIVATIVES } \\
\hline Ascochitine & $38.5 \mu \mathrm{M}$ & Benzopyran derivative & Ascochyta salicorniae [63] \\
\hline Sanggenon $\mathrm{C}$ & $2.6 \mu \mathrm{M}$ & Benzopyran derivative & Morus [135] \\
\hline Sanggenon G & $1.6 \mu \mathrm{M}$ & Benzopyran derivative & Morus $[135]$ \\
\hline Mulberrofuran C & $4.9 \mu \mathrm{M}$ & Benzopyran derivative & Morus $[135]$ \\
\hline Kuwanon L & $16.9 \mu \mathrm{M}$ & Benzopyran derivative & Morus $[135]$ \\
\hline
\end{tabular}


(Table 1A) contd....

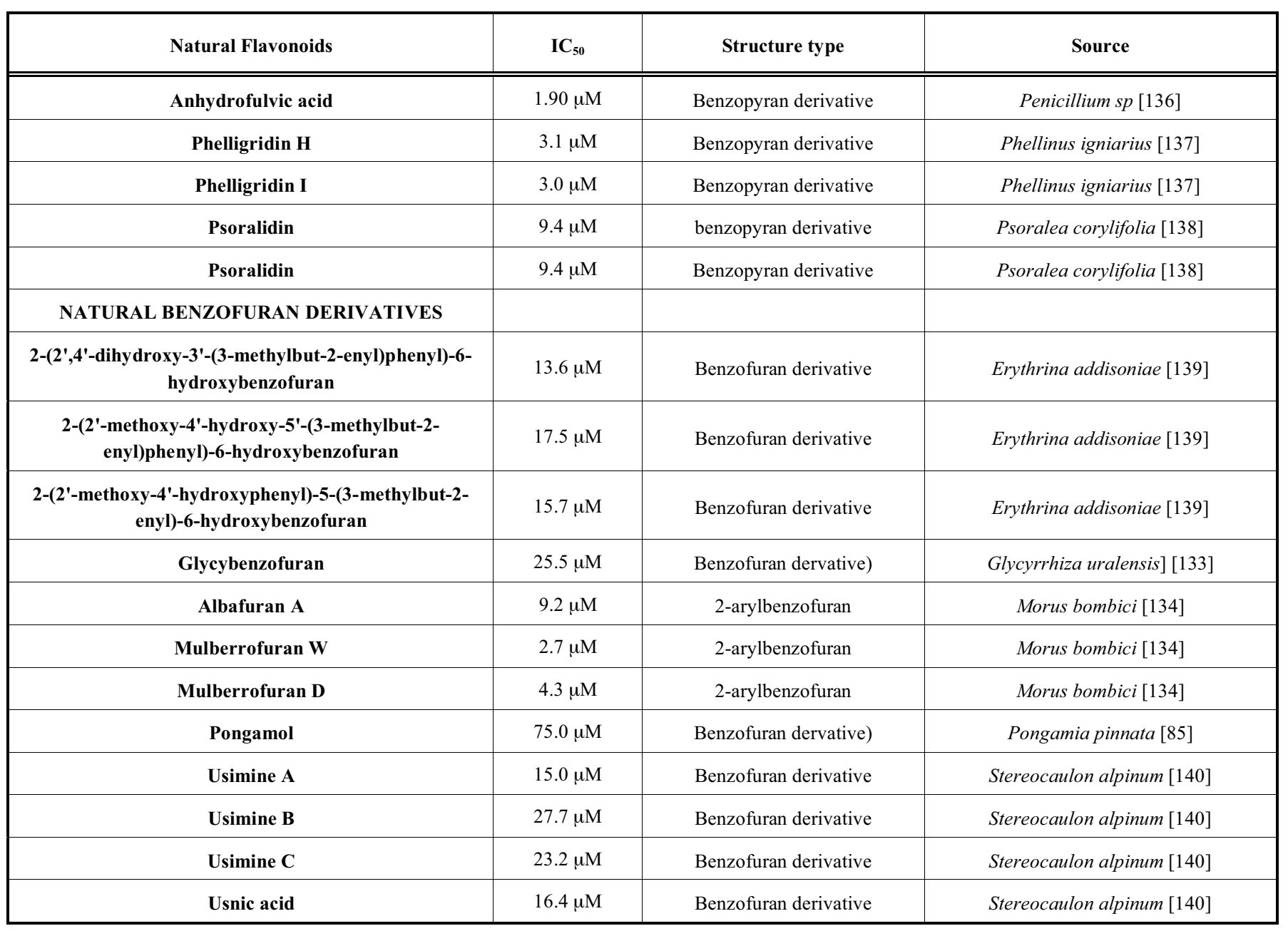

Table 1B. Natural inhibitors of PTP1B.

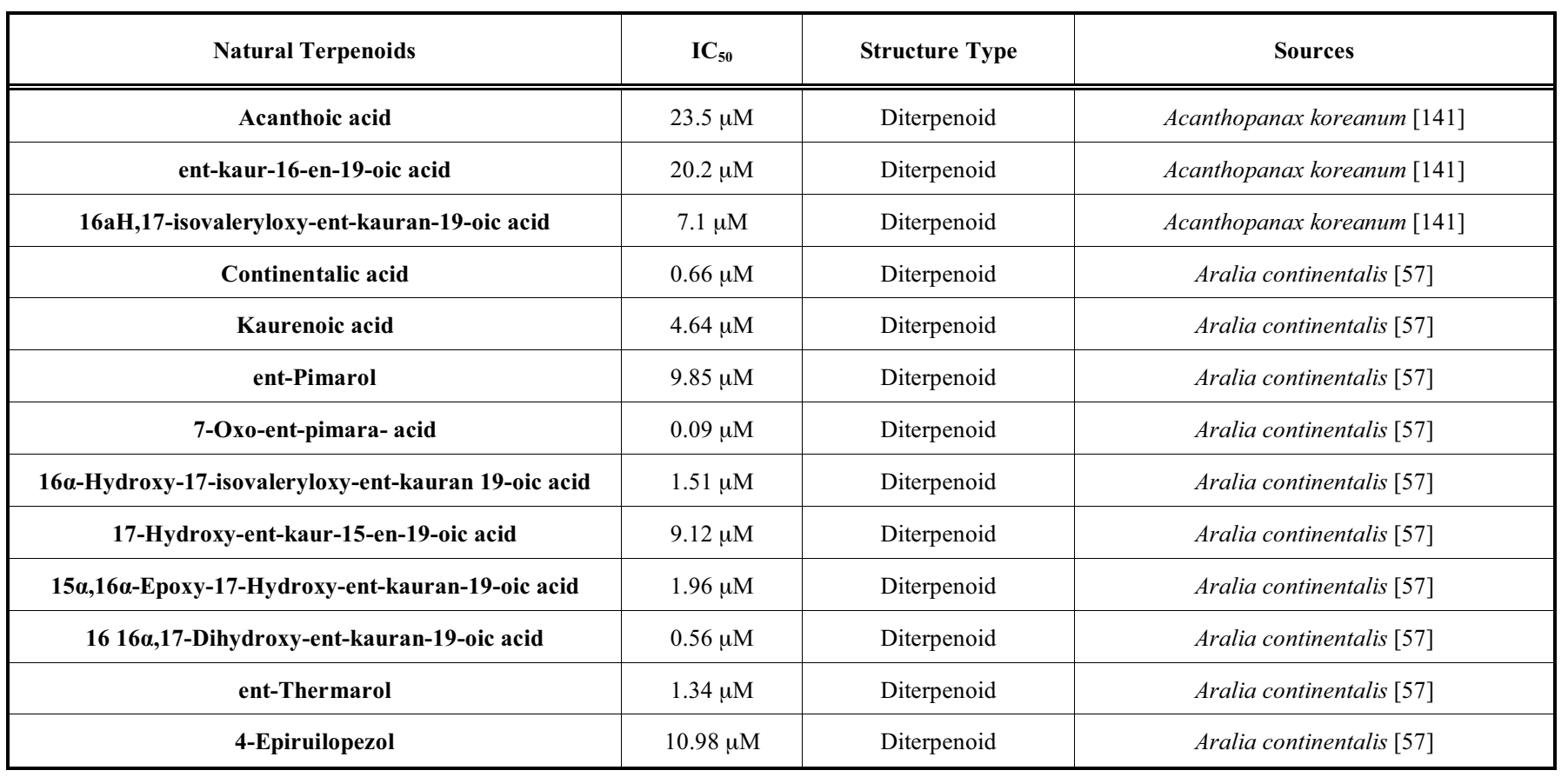


(Table 1B) contd....

\begin{tabular}{|c|c|c|c|}
\hline Natural Terpenoids & $\mathbf{I C}_{50}$ & Structure Type & Sources \\
\hline ent-pimara-8(14),15-diene-19-oic acid (continentalic acid) & $2.85 \mu \mathrm{M}$ & Diterpenoids & Aralia continentalis $[62]$ \\
\hline 7-oxo-ent-pimara-8(14),15-diene-19-oic acid & $2.60 \mu \mathrm{M}$ & Diterpenoids & Aralia continentalis $[62]$ \\
\hline ent-pimara-8(14),15-diene-19-ol (ent-pimarol) & $12.95 \mu \mathrm{M}$ & Diterpenoids & Aralia continentalis [62] \\
\hline 8a-hydroxy-ent-pimara-15-en-19-ol (ent-thermarol) & $7.06 \mu \mathrm{M}$ & Diterpenoids & Aralia continentalis $[62]$ \\
\hline ent-kaur-16-en-19-oic-acid (kaurenoic acid & $8.27 \mu \mathrm{M}$ & Diterpenoids & Aralia continentalis $[62]$ \\
\hline 3-Oxoolean-12-en-27-oic acid & $6.8 \mu \mathrm{M}$ & Triterpene & Astilbe koreana $[142]$ \\
\hline $\begin{array}{l}\text { 3b-Hydroxyolean-12-en-27-oic acid (b-peltoboy-kinolic } \\
\text { acid }\end{array}$ & $5.2 \mu \mathrm{M}$ & Triterpene & Astilbe koreana $[142]$ \\
\hline 3b-Hydroxyurs-12-en-27-oic acid & $4.9 \mu \mathrm{M}$ & Triterpene & Astilbe koreana $[142]$ \\
\hline 3a,24-Dihydroxyolean-12-en-27-oic acid & $11.7 \mu \mathrm{M}$ & Triterpene & Astilbe koreana [142] \\
\hline 3b,6b-Dihydroxyolean-12-en-27-oic acid (astilbic acid) & $12.8 \mu \mathrm{M}$ & Triterpene & Astilbe koreana $[142]$ \\
\hline 11-keto boswellic acid & $8.04 \mu \mathrm{M}$ & Triterpene & Boswellia carteri $[71]$ \\
\hline Oleanolic acid & $3.37 \mu \mathrm{M}$ & Triterpene & Calendula. officinalis [71] \\
\hline Ursolic acid & $3.08 \mu \mathrm{M}$ & Triterpenoids & Calendula. officinalis [71] \\
\hline Corosolic acid & $5.49 \mu \mathrm{M}$ & Triterpenoids & Calendula. officinalis [71] \\
\hline Madecassic acid & $12.38 \mu \mathrm{M}$ & Triterpene & Centella asiatica $[71]$ \\
\hline Ursolic acid & $3.08 \mu \mathrm{M}$ & Triterpenoids & Cornus officinalis [67] \\
\hline O-Methyl nakafuran-8 lactone & $1.58 \mu \mathrm{M}$ & Sesquiterpenoid & Dysidea sp [143] \\
\hline Hydroxybutenolide & $8.8 \mu \mathrm{g} / \mathrm{mL}$ & Sesquiterpene & Dysidea septosa [144] \\
\hline Microcionin-4 & $11.6 \mu \mathrm{g} / \mathrm{mL}$ & Sesquiterpene & Dysidea septosa [144] \\
\hline dihy dropallescensin-2 & $6.8 \mu \mathrm{g} / \mathrm{mL}$ & Sesquiterpene & Dysidea septosa [144] \\
\hline Nakafuran-8 & $1.9 \mu \mathrm{g} / \mathrm{mL}$ & Sesquiterpenoid & Dysidea septosa [144] \\
\hline Dysidine & $6.70 \mu \mathrm{M}$ & Sesquiterpene & Dysidea villosa [145] \\
\hline 21-Dehydroxybolinaquinone & $39.50 \mu \mathrm{M}$ & Sesquiterpene quinone & Dysidea villosa [145] \\
\hline Betulin & $15.3 \mu \mathrm{M}$ & Triterpene & Euphorbia micractina [72] \\
\hline $\begin{array}{l}\text { (23S)-3b,20z,21z-trihydroxy-19-oxo-21,23- } \\
\text { epoxydammarane-24-ene }\end{array}$ & $19.3 \mu \mathrm{M}$ & Triterpene & Gynostemma pentaphyllum [146] \\
\hline 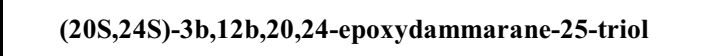 & $20.4 \mu \mathrm{M}$ & Triterpene & Gynostemma pentaphyllum [146] \\
\hline$(20 S, 24 S)-3 b, 12 b, 20,24$-epoxy-12,25-dihydroxydammarane & $21.7 \mu \mathrm{M}$ & Triterpene & Gynostemma pentaphyllum $[146]$ \\
\hline (20S),3b,21-trihydroxy-25-methoxydammarane-23-ene & $25.1 \mu \mathrm{M}$ & Triterpene & Gynostemma pentaphyllum $[146]$ \\
\hline$(20 S)-3 b, 12 b, 12,25$-dihydroxydammar-23-ene & $28.5 \mu \mathrm{M}$ & Triterpene & Gynostemma pentaphyllum [146] \\
\hline 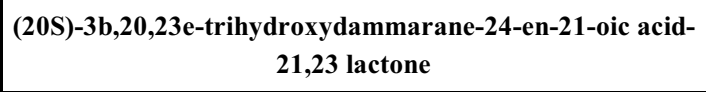 & $5.3 \mu \mathrm{M}$ & Triterpene & Gynostemma pentaphyllum $[146]$ \\
\hline $\begin{array}{l}\text { (20R)-3b,20,23e-trihydroxydammarane-24-en-21-oic acid- } \\
21,23 \text { lactone }\end{array}$ & $5.7 \mu \mathrm{M}$ & Triterpene & Gynostemma pentaphyllum [146] \\
\hline Hueafuranoid A & $13.9 \mu \mathrm{M}$ & Diterpene furanoid & Huеa sp [147] \\
\hline Hyrtiosal & $42 \mu \mathrm{M}$ & Sesterterpenoid & Hyrtios erectus [86] \\
\hline Sulfircin & $29.8 \mu \mathrm{M}$ & Sesterterpene & Ircinia $[148]$ \\
\hline
\end{tabular}


(Table 1B) contd....

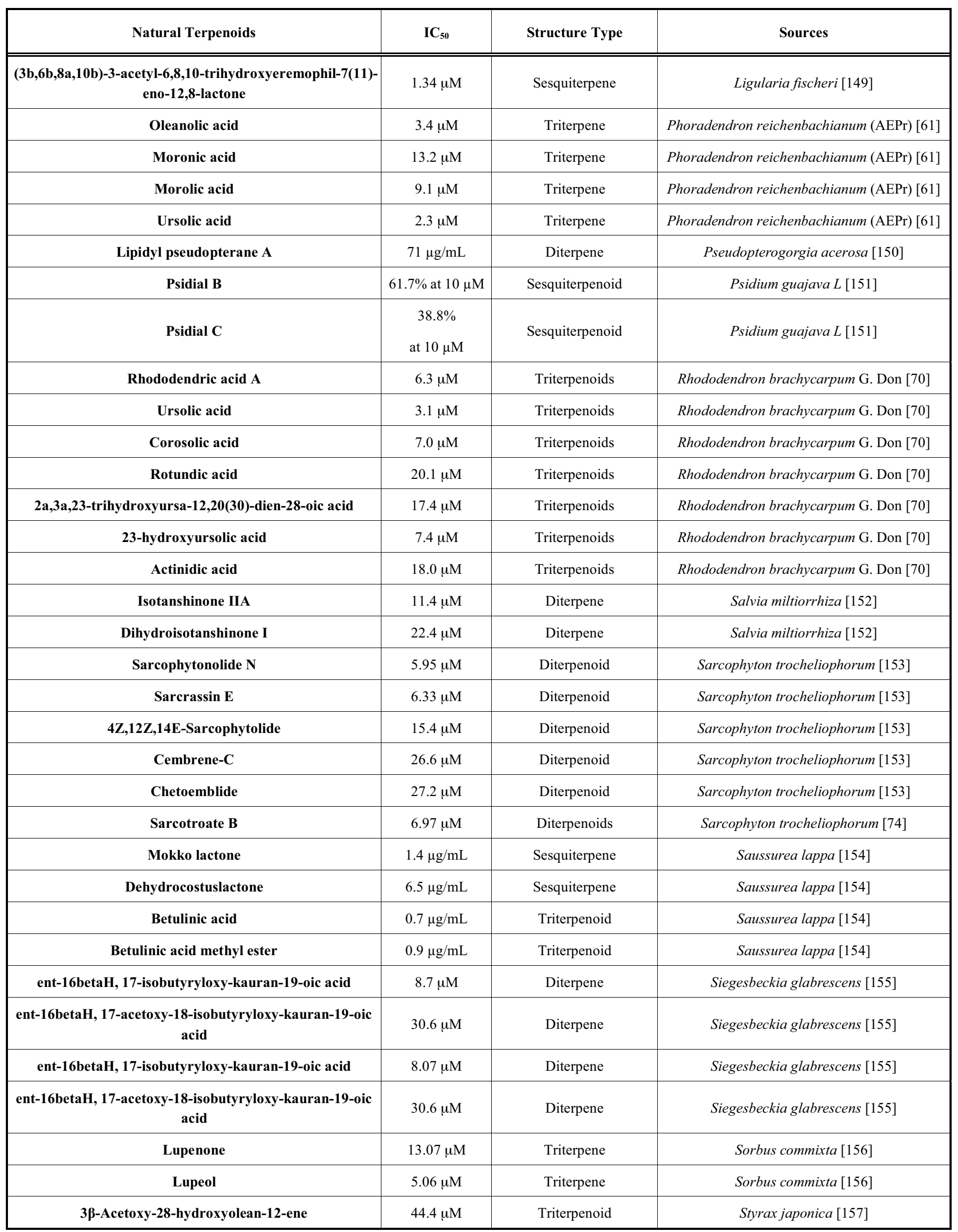


(Table 1B) contd....

\begin{tabular}{|c|c|c|c|}
\hline Natural Terpenoids & $\mathbf{I C}_{50}$ & Structure Type & Sources \\
\hline 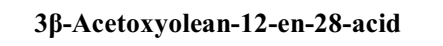 & $7.8 \mu \mathrm{M}$ & Triterpenoid & Styrax japonica $[157]$ \\
\hline 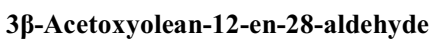 & $9.3 \mu \mathrm{M}$ & Triterpenoid & Styrax japonica [157] \\
\hline 3ß-Hydroxyolean-12-en-28-oic acid & $5.2 \mu \mathrm{M}$ & Triterpenoid & Styrax japonica $[157]$ \\
\hline Glycyrrhetic acid & $13.8 \mu \mathrm{M}$ & Ttriterpenoid & Styrax japonica $[157]$ \\
\hline Ursolic acid & $3.8 \mu \mathrm{M}$ & Triterpene & Symplocos paniculata [68] \\
\hline Corosolic acid & $7.2 \mu \mathrm{M}$ & Triterpene & Symplocos pani culata $[68]$ \\
\hline Ilekudinol A & $29.1 \mu \mathrm{M}$ & Triterpene & Weigela subsessilis [158] \\
\hline Ilekudinol B & $5.3 \mu \mathrm{M}$ & Triterpene & Weigela subsessilis [158] \\
\hline Corosolic acid & $5.49 \mu \mathrm{M}$ & Triterpene & Several traditional Chinese medicinal herbs [66] \\
\hline
\end{tabular}

Table 1C. Natural inhibitors of PTP1B.

\begin{tabular}{|c|c|c|c|}
\hline Compound & $\mathrm{IC}_{50}$ & Structure Type & Source \\
\hline Caffeic acid & $3.06 \mu \mathrm{M}$ & Cnnamic acid derivative & Artemisia minor $[159]$ \\
\hline Compound 1 & $3.7 \mu \mathrm{M}$ & Vanillic acid derivative & Cladophora socialis $[160]$ \\
\hline Compound 2 & $1.7 \mu \mathrm{M}$ & Vanillic acid derivative & Cladophora socialis $[160]$ \\
\hline Curcumin & $\begin{array}{l}\text { In vivo PTP1B } \\
\text { inhibitor }\end{array}$ & Phenol derivative & Curcuma longa [79] \\
\hline Cyclospirolide & $16.64 \mu \mathrm{M}$ & Phenol derivative & Cyclocarya paliurus [122] \\
\hline Caffeic acid & $1,92 \mu \mathrm{M}$ & Cinnamic acid derivative & Cyclocarya paliurus [122] \\
\hline 1,2,3,4,6-penta-O-galloyl-D-glucopyranose & $4.8 \mu \mathrm{M}$ & Gallic acid derivative & Paeonia lactiflora [75] \\
\hline 3,4-dihydroxy benzoic acid & $52.9 \mu \mathrm{M}$ & Benzoic acid derivative & Phellinus linteus [161] \\
\hline Bakuchiol & $20.8 \mu \mathrm{M}$ & Phenol derivative & Psoralea corylifolia $[138]$ \\
\hline $\begin{array}{c}2,2^{\prime}, 3,3^{\prime} \text {-tetrabromo- } 4,4^{\prime}, 5,5^{\prime} \text {-tetrahydroxydiphenyl } \\
\text { methane }\end{array}$ & $2.4 \mu \mathrm{M}$ & Bromophenol derivative & Rhodomela confervoides [162] \\
\hline $\begin{array}{c}\text { 3-bormo-4,5-bis(2,3-dibromo-4,5-dihydroxybenzyl) } \\
\text { pyrocatechol }\end{array}$ & $1.7 \mu \mathrm{M}$ & Bromophenol derivative & Rhodomela confervoides [162] \\
\hline bis(2,3-dibromo-4,5-dihydroxybenzyl) ether & $1.5 \mu \mathrm{M}$ & Bromophenol derivative & Rhodomela confervoides [162] \\
\hline $\begin{array}{l}\text { 2,2',3-tribromo-3',4,4',5-tetrahydroxy-6'- } \\
\text { ethyloxymethyldiphenylmethane }\end{array}$ & $0.84 \mu \mathrm{M}$ & Bromophenol derivative & Rhodomela confervoides [162] \\
\hline 3, 4-dibromo-5-(methoxymethyl)-1, 2-benzenediol & $3.4 \mu \mathrm{M}$ & Bromophenol derivative & Rhodomela confervoides and Leathesia nana [163] \\
\hline $\begin{array}{l}\text { 2-methyl-3-(2, 3-dibromo4, 5-dihydroxy)- } \\
\text { propylaldehyde }\end{array}$ & $4.5 \mu \mathrm{M}$ & Bromophenol derivative & Rhodomela confervoides and Leathesia nana [163] \\
\hline $\begin{array}{l}\text { 3-(2, 3-dibromo-4, 5-dihydroxy-phenyl)-4-bromo-5, } \\
\text { 6-dihydroxy-1, 3-dihydroiso-benzofuran }\end{array}$ & $2.8 \mu \mathrm{M}$ & Bromophenol derivative & Rhodomela confervoides and Leathesia nana [163] \\
\hline 2,3-dibromo-4,5-dihydroxybenzyl methyl ether & $39.0 \mu \mathrm{M}$ & Bromophenol derivative & Symphyocladia latiuscula [164] \\
\hline 2,3,6-tribromo-4,5-dihydroxybenzaldehyde & $19.4 \mu \mathrm{M}$ & Bromophenol derivative & Symphyocladia latiuscula [164] \\
\hline 2,3,6-tribromo-4,5-dihydroxybenzyl methyl ether & $3.9 \mu \mathrm{M}$ & Bromophenol derivative & Symphyocladia latiuscula [164] \\
\hline bis(2,3,6-tribromo-4,5-dihy droxyphenyl)methane & $4.3 \mu \mathrm{M}$ & Bromophenol derivative & Symphyocladia latiuscula $[164]$ \\
\hline
\end{tabular}


(Table 1C) contd....

\begin{tabular}{|c|c|c|c|}
\hline Compound & IC $_{\mathbf{5 0}}$ & Structure Type & Source \\
\hline \hline 1,2-bis(2,3,6-tribromo-4,5-dihydroxyphenyl)-ethane & $3.5 \mu \mathrm{M}$ & Bromophenol derivative & Symphyocladia latiuscula [164] \\
\hline $\begin{array}{c}\mathbf{1 - ( 2 , 3 , 6 - t r i b r o m o - 4 , 5 - d i h y d r o x y b e n z y l ) - p y r r o l i d i n -} \\
\text { 2-one }\end{array}$ & $25.6 \mu \mathrm{M}$ & Bromophenol derivative & Symphyocladia latiuscula [164] \\
\hline Gyrophoric acid & $3.6 \mu \mathrm{M}$ & Benzoic acid derivative & Umbilicaria antartica $[165]$ \\
\hline lecanoric acid & $31 \mu \mathrm{M}$ & Benzoic acid derivative & Umbilicaria antartica $[165]$ \\
\hline
\end{tabular}

Table 1D. Natural inhibitors of PTP1B.

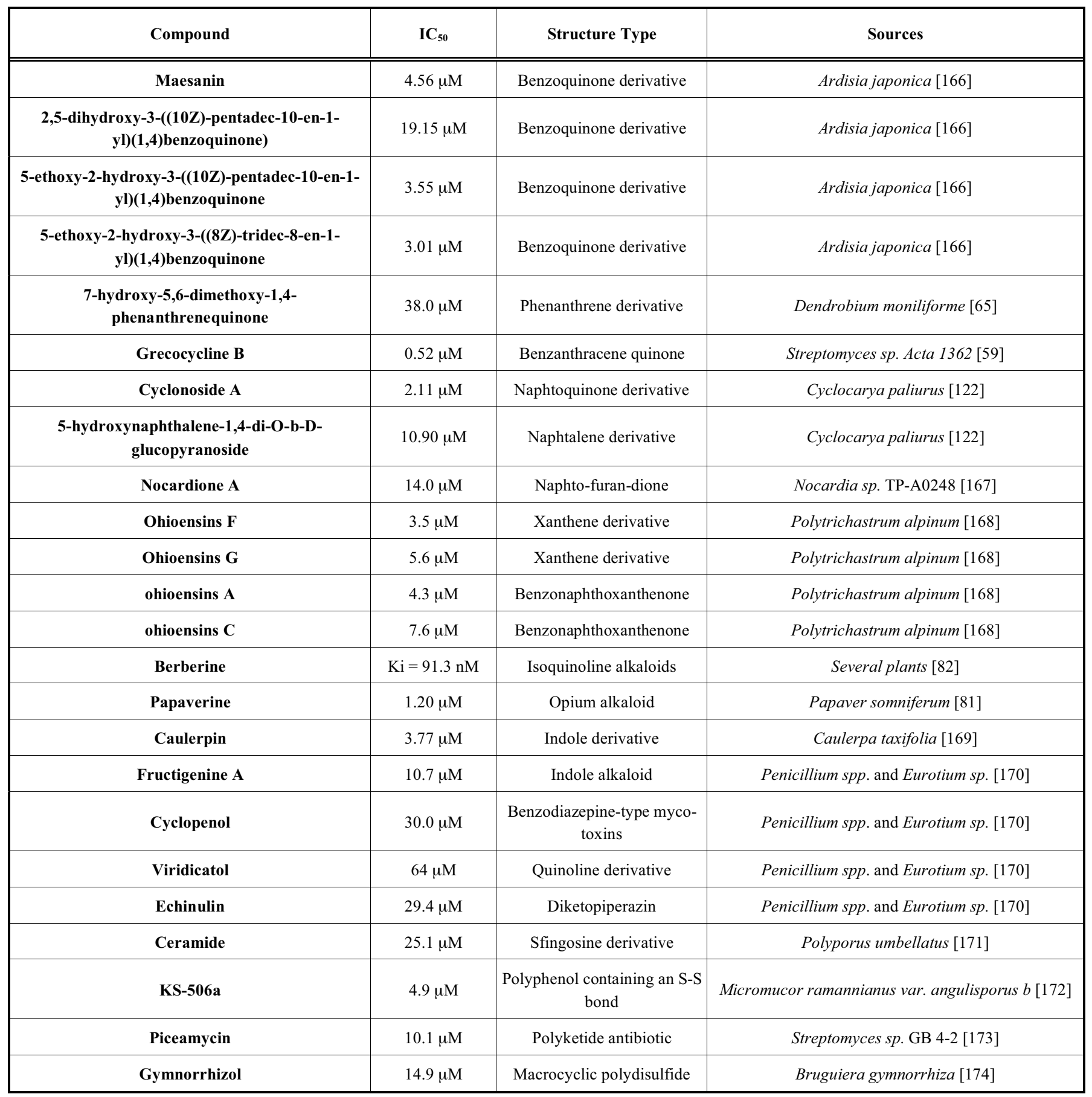


(Table 1D) contd....

\begin{tabular}{|c|c|c|c|}
\hline Compound & $\mathbf{I C}_{50}$ & Structure Type & Sources \\
\hline Bruguiesulfurol & $17.6 \mu \mathrm{M}$ & Cyclic disulfides & Bruguiera gymnorrhiza [175] \\
\hline Falcarindiol & $9.15 \mu \mathrm{M}$ & Fatty alcohol & Aegiceras corniculatum [176] \\
\hline Flavoglaucin & $13.4 \mu \mathrm{M}$ & Benzaldehyde derivative & Penicillium spp. and Eurotium sp. [170] \\
\hline 3',5',6',6-tetrabromo-2,4-dimethyldiphenyl ether & $2.97 \mu \mathrm{M}$ & Benzene derivative & Laurencia similis [177] \\
\hline $\begin{array}{l}2^{\prime}, 5^{\prime}, 6 \text { ',5,6-pentabromo-3',4',3,4- } \\
\text { tetramethoxybenzo-phenone }\end{array}$ & $2.66 \mu \mathrm{M}$ & Benzene derivative & Laurencia similis [177] \\
\hline Woodylide C & $4.7 \mathrm{mg} / \mathrm{mL}$ & Polyketide & Plakortis simplex [178] \\
\hline Hippolide A & $23.81 \mu \mathrm{M}$ & Acylic manoalide derivative & Hippospongia lachne [179] \\
\hline Hippolide B & $39.67 \mu \mathrm{M}$ & Acylic manoalide derivative & Hippospongia lachne [179] \\
\hline Manzamenone B & $10.8 \mu \mathrm{M}$ & Fatty acid derivatives & Plakortis (unknown species) [180] \\
\hline Manzamenone E & $13.5 \mu \mathrm{M}$ & Fatty acid derivatives & Plakortis (unknown species [180] \\
\hline Albidopyrone & $128 \mu \mathrm{g} / \mathrm{mL}$ & Pyrone derivative & Streptomyces sp. NTK 227 [181] \\
\hline $\begin{array}{l}\text { 3-Hexadecanoyl-5-hydroxymethyl tetronic acid } \\
\text { (RK-682) }\end{array}$ & $4.5 \mu \mathrm{M}$ & Furandione derivative & Streptomyces [135] \\
\hline Lobaric acid & $0.87 \mu \mathrm{M}$ & Depsidone-type & Stereocaulon alpinum [182] \\
\hline Pseudodepsidone-type compound 2 & $6.86 \mu \mathrm{M}$ & Pseudodepsidone-type & Stereocaulon alpinum [182] \\
\hline Pseudodepsidone-type compound 3 & $2.48 \mu \mathrm{M}$ & Pseudodepsidone-type & Stereocaulon alpinum [182] \\
\hline Stereocalpin & $40 \mu \mathrm{M}$ & cyclic Depsipeptide & Stereocaulon alpinum [182] \\
\hline Aquastatin A & $0.19 \mu \mathrm{M}$ & $\beta$-Galactopyranoside & Cosmospora sp. SF-5060 [58] \\
\hline Episesamin 2,6-dicatechol & $21.86 \mu \mathrm{M}$ & Lignan derivative & Morinda citrifolia [69] \\
\hline$(-)$-Pinoresinol & $18.69 \mu \mathrm{M}$ & Lignan derivative & Morinda citrifolia [69] \\
\hline Lirioresinol B & $15.01 \mu \mathrm{M}$ & Lignan derivative & Morinda citrifolia [69] \\
\hline Lirioresinol B dimethyl ether & $16.82 \mu \mathrm{M}$ & Lignan derivative & Morinda citrifolia [69] \\
\hline meso-dihydroguaiaretic acid & $19.6 \mu \mathrm{M}$ & Lignan derivative & Myristica fragrans [183] \\
\hline Otobaphenol & $48.9 \mu \mathrm{M}$ & Lignan derivative & Myristica fragrans [183] \\
\hline Ratanhiaphenol III & $20.2 \mu \mathrm{M}$ & Lignan derivative & Krameria lappacea $[76]$ \\
\hline $\begin{array}{c}\text { (7R,8R)-3-methoxy-1'-carboxy-4',7-epoxy-8,3'- } \\
\text { oxyneolignan-4,9-diol }\end{array}$ & $19.56 \mu \mathrm{M}$ & Neolignan & Morinda citrifolia $[69]$ \\
\hline (Z)-aglawone & $1.12 \mu \mathrm{g} / \mathrm{mL}$ & Steroid & Toona ciliata var. pubescens [184] \\
\hline Trodusquemine & $1 \mu \mathrm{M}$ & Aminosterol & Squalus acanthias [87], [185 ] \\
\hline $\begin{array}{c}\text { (2S,3S,4R,2'R)-2-(2'-hydroxytricosanoylamino)- } \\
\text { nonadecane-1,3,4-triol }\end{array}$ & $25.1 \mu \mathrm{g} / \mathrm{mL}$ & Steroids & Polyporus umbellatus [171] \\
\hline 19-norergosta-5,7,9,22-tetraene-3 $\beta$-ol & $8.9 \mu \mathrm{g} / \mathrm{mL}$ & Steroids & Polyporus umbellatus [171] \\
\hline 24-ethylcholesta-7,22-diene-3 $3,5 \alpha, 6 \beta$-triol & $6.5 \mu \mathrm{g} / \mathrm{mL}$ & Steroids & Polyporus umbellatus [171] \\
\hline 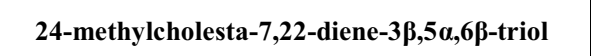 & $7.5 \mu \mathrm{g} / \mathrm{mL}$ & Steroids & Polyporus umbellatus [171] \\
\hline Penstyrylpyrone & 5.28 & Pyrone derivative & Penicillium sp [136] \\
\hline Dihydrocarolic acid & $38 \mu \mathrm{g} / \mathrm{mL}$ & Furan derivative & Aspergillus niger [64] \\
\hline Penitricin D & $15.8 \mu \mathrm{g} / \mathrm{mL}$ & Cyclopropan derivative & Aspergillus niger [64] \\
\hline
\end{tabular}


$\mathrm{IC}_{50}=3.08 \mu \mathrm{M}$ [67], $\mathrm{IC}_{50}=3.8 \mu \mathrm{M}[68], \mathrm{IC}_{50}=4.12 \mu \mathrm{M}$ [69], $\mathrm{IC}_{50}=3.1 \mu \mathrm{M}[70], \mathrm{IC}_{50}=2.3 \mu \mathrm{M}$ [61]; ii) TC-PTP $\mathrm{IC}_{50}$ value $=3.33 \mu \mathrm{M}$ [67]; iii) $\mathrm{SHP} 2\left(\mathrm{IC}_{50}\right.$ value $\left.=2.73 \mu \mathrm{M}\right)$ [67]; iv) $\mathrm{LAR}\left(\mathrm{IC}_{50}\right.$ value $\left.=3.8 \mu \mathrm{M}\right)$ [61]. Furthermore, ursolic acid enhances insulin receptor phosphorylation in $\mathrm{CHO} / \mathrm{hIR}$ cells and stimulates glucose uptake in L6 myotubes [67]. In addition this compound shows significant antidiabetic activity in Streptozotocin-nicotinamide diabetic rats [61]. Oleanolic acid, a triterpene contained in traditional Chinese medicinal herbs [71], is another PTP1B inhibitor $\left(\mathrm{IC}_{50}\right.$ value $=9.5 \mu \mathrm{M}$ [61]; $4.2 \mu \mathrm{M}$ [72]; $23.9 \mu \mathrm{M}[73] ; 3.37$ $\mu \mathrm{M}[71] ; 2.56 \mu \mathrm{M}[74])$. Oleanolic acid is active in vivo, showing a moderate antidiabetic activity in Streptozotocinnicotinamide diabetic rats [61]. The lignans episesamin 2,6dicatechol $\left(\mathrm{IC}_{50}\right.$ value $=21.86 \mu \mathrm{M}$ on PTP1B $)$, lirioresinol $\mathrm{B}$ $\left(\mathrm{IC}_{50}\right.$ value $\left.=15.01 \mu \mathrm{M}\right)$, and lirioresinol $\mathrm{B}$ dimethyl ether $\left(\mathrm{IC}_{50}\right.$ value $\left.=16.82 \mu \mathrm{M}\right)$, extracted from Morinda citrifolia [69], show a strong stimulatory action on 2-NBDG uptake in 3T3-L1 adipocyte cells. The compound 1,2,3,4,6-penta-Ogalloyl-D-glucopyranose $\left(\mathrm{IC}_{50}\right.$ value $=4.8 \mu \mathrm{M}$ on PTP1B) acts as an insulin sensitizer in human hepatoma cells [75]. The lignan ratanhiaphenol III $\left(\mathrm{IC}_{50}\right.$ value $=20.2 \mu \mathrm{M}$ on PTP1B) is able to increase IR phosphorylation as well as glucose uptake stimulated by insulin in cultured myotubes [76]. The treatment of $32 \mathrm{D}$ cells overexpressing the IR with amentoflavone, a non competititve inhibitor of PTP1B $\left(\mathrm{IC}_{50}\right.$ value $=7.3 \mu \mathrm{M}$ ) extracted from Selaginella tamariscina, induces a dose-dependent increase in IR tyrosine phosphorylation [77]. The PTP1B inhibitors 3',5'-diprenylgenistein $\left(\mathrm{IC}_{50}\right.$ value $\left.=31.75 \mu \mathrm{M}\right), 6,8$-diprenylgenistein $\left(\mathrm{IC}_{50}\right.$ value $=$ $28.13 \mu \mathrm{M})$, derrone $\left(\mathrm{IC}_{50}\right.$ value $\left.=20.63 \mu \mathrm{M}\right)$ and alpinumisoflavone $\left(\mathrm{IC}_{50}\right.$ value $\left.=37.52 \mu \mathrm{M}\right)$, extracted from Tetracera scandens, exhibit a significant glucose-uptake activity in basal and insulin-stimulated L6 myotubes [78]. The flavonol Morin, a non-competitive inhibitor of PTP1B $\left(\mathrm{IC}_{50}\right.$ value $=$ $15 \mu \mathrm{M})$, inhibits also other two enzymes that antagonize IR signaling, i.e. TC-PTP $\left(\mathrm{IC}_{50}\right.$ value $\left.=19.1 \mu \mathrm{M}\right)$ and $\mathrm{LMW}$ PTP $\left(\mathrm{IC}_{50}\right.$ value $\left.=36.4 \mu \mathrm{M}\right)$. Morin is able to increase IR and Akt phosphorylation as well as to inhibit gluconeogenesis and to enhance glycogen synthesis in HepG2 cells [60]. The action of morin is selective for the insulin signaling, since it is unable to stimulate phosphorylation of other tyrosine kinase receptors such as EGFR and PDGFR. Curcumin, which is a phenolic compound extracted from Curcuma longa, produces a number of biological actions being a PTP1B inhibitor in vivo. In fact, in fructose-fed rats it is able: i) to reduce serum insulin and leptin levels; ii) to increase phosphorylation of insulin receptor and IRS-1 enhancing Akt and ERK $1 / 2$ activation in the liver; iii) to increase phosphorylation of hepatic janus-activated kinase-signal transducer 2 and subsequently to stimulate activation of Akt and ERK1/2 [79]. Fructose decreases tyrosine phosphorylation of IRS1 and inhibits activation of Akt and extracellular signalregulated kinase $1 / 2(E R K 1 / 2)$ in peripheral tissues of rats [80]. Papaverine, which is an opium alkaloid contained in Papaver somniferum, is a strong $\mathrm{PTP} 1 \mathrm{~B}$ inhibitor $\left(\mathrm{IC}_{50}=\right.$ $1.20 \mu \mathrm{M})$. In vivo, papaverine significantly decreases fasting blood glucose level of Balb/c mice [81]. Berberine, an alkaloid contained in several plant species, mimics insulin action by increasing glucose uptake in 3T3-L1 adipocytes and L6 myocytes inhibiting the phosphatase activity of PTP1B $(\mathrm{Ki}$ value (competitive) $=91.3 \mathrm{nM}$ ) [82] and increasing the phosphorylation of IR, IRS1 and Akt. Furthermore, berberine lowers hyperglycaemia and improves impaired glucose tolerance in diabetic mice [83], as well as elicits antidiabetic effects in clinical trials [84]. The compounds pongamol and karanjin, extracted from Pongamia pinnata fruits, exert a moderate but significant inhibitory effect on PTP1B; in addition they are able to decrease blood glucose levels both in streptozotocin-induced diabetic rats and in $\mathrm{db} / \mathrm{db}$ mice [85]. Moronic acid and morolic acid, two terpenic acids extracted from Phoradendron reichenbachianum and from other plants, are able to induce a significant decrease in plasma glucose concentration in streptozotocin-nicotinamide diabetic rats. Moronic acid is a mixed type inhibitor of PTP1B displaying an $\mathrm{IC}_{50}$ value of $13.2 \mu \mathrm{M}$, whereas morolic acid is a non-competitive inhibitor of PTP1B displaying and $\mathrm{IC}_{50}$ value of $9.1 \mu \mathrm{M}$ [61]. Hyrtiosal, extracted from the marine sponge Hyrtios erectus, is a non competitive inhibitor of PTP1B $\left(\mathrm{IC}_{50}=42 \mu \mathrm{M}\right)$ that displays potent activity in abolishing the retardation of AKT membrane translocation caused by PTP1B overexpression in CHO cells. Furthermore hyrtiosal dramatically enhances the membrane translocation of GLUT4 in PTP1B-overexpressed CHO cells [86]. The aminosterol trodusquemine is a potent allosteric non competitive inhibitor of PTP1B. Trodusquemine's inhibition is highly selective for PTP1B, since its $\mathrm{IC}_{50}$ value $(224 \mu \mathrm{M})$ for TC-PTP (70\% sequence identity with PTP1B) was approximately two logs less than that against PTP1B $(1 \mu \mathrm{M})$. This compound, isolated from the liver of the dogfish shark Squalus acanthias, is able to inhibit PTP1B activity in HepG2 cells, resulting more potent than orthovanadate, a well known non specific tyrosine phosphatase inhibitor [87]. Lantz et al. [87] reported that in HepG2 cells trodusquemine enhances insulin-induced tyrosine phosphorylation of IR $\beta$ about three-fold, whereas trodusquemine by itself (in the absence of insulin) had no effect. Trodusqueamine acts also in vivo both on central and peripheral tissues displaying a very interesting insulin sensitizing activity. In fact, trodusquemine-treated rats show an approximately twofold increase in insulin-induced tyrosine phosphorylation of hypothalamic IR $\beta$ and a 5.4-fold increase in phosphorylation of STAT3, a downstream transcription factor. Trodusquemine itself has no effect on tyrosine phosphorylation of IR $\beta$ but induces a 2.7-fold increase of STAT3 phosphorylation in hypothalamus. Furthermore systemic administration of trodusquemine in mice results in enhanced insulin-induced phosphorylation of IRS1 andAkt in the liver, demonstrating its peripheral activity [88].

\section{Natural Substances that Increase Glucose Uptake Acting Through the AMPK Activation}

Compelling evidences suggest that in most cases antihyperglycaemic effects of natural compounds are mediated by AMPK, the same molecular target of metformin [89]. Therefore, several of these natural compounds could be used to treat T2DM or as scaffold structures to design and synthesize more potent and selective drugs. AMPK is a key player in the response to a variety of metabolic stresses and it is directly involved in the regulation of GLUT4 trafficking on the plasma membrane [90] (Fig. 3). Unlike insulin, AMPK is activated in response to stress conditions or stimuli that cause a decrease of ATP levels such as physical activity, 


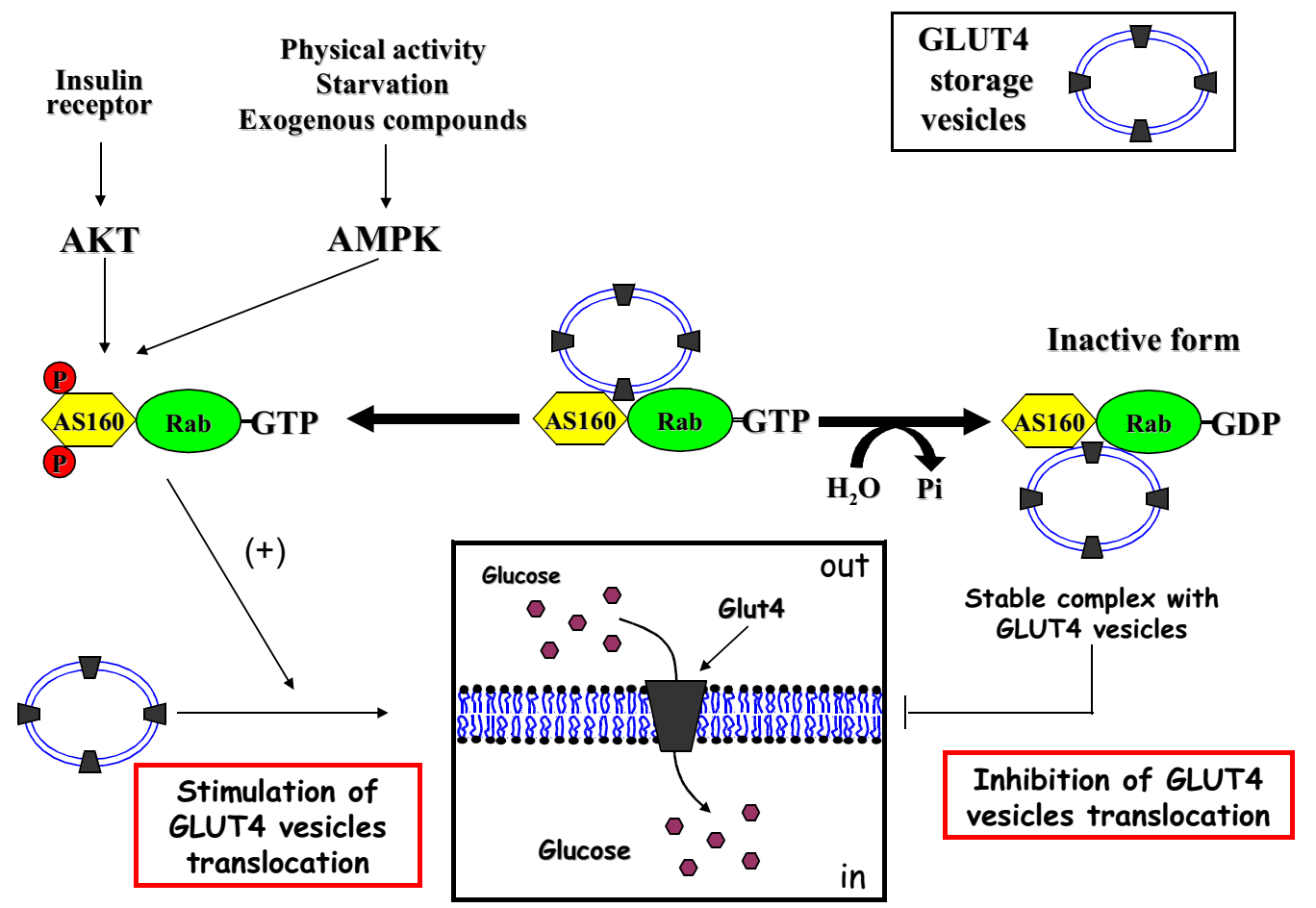

Fig. (3). Two signaling pathways involved in the regulation of GLUT4 translocation onto the plasma membrane. AKT and AMPK phosphorylate AS160 on multiple phosphorylation sites. AS160, which contains a Rab-GAP domain, is a key protein responsible for GLUT4 translocation onto plasma membrane. In insulin-sensitive cells and in the absence of hormone or stress stimuli (such as nutrient starvation or muscle contraction), Rab-GTP proteins interact with AS160; in turn, the AS160-Rab-GTP complex interacts with GLUT4 storage vesicles. Non-phosphorylated AS160 stimulates the GTPase activity of the Rab proteins which are converted in their inactive state (Rab-GDP). AS160-Rab-GDP forms a stable complex with GLUT4 storage vesicles but is unable to stimulate actin remodelling, an essential event to trigger GLUT4 vesicles translocation onto the plasma membrane. On the contrary, insulin or AMPK-mediated phosphorylation of AS160 inhibits the Rab-GAP GTPase activity, thereby eliciting accumulation of Rab-GTP. Consequently, AS160-Rab-GTP complex dissociates from GLUT4 storage vesicles, promoting actin remodeling and translocation of GLUT4 onto the plasma membrane. For an explanation of acronyms see 'Abbreviations'.

nutrients deprivation or the presence of metabolic inhibitors. High rate of ATP consumption contribute to increase intracellular levels of AMP, a potent positive allosteric effector of AMPK. Once activated, AMPK phosphorylates several key enzymes involved in the metabolic regulation, inhibiting the synthesis of macromolecules and stimulating catabolic pathways [91]. Although the mechanism by which the AMPK stimulates glucose uptake is not completely defined, most of key players involved in this process have been identified. One target of AMPK is AS160 protein. This is a GTPase activating protein that usually forms a stable complex with Rab proteins, a family of small GTP-binding proteins related to Ras and involved in the membrane trafficking regulation. After insulin stimulation, AS160 is phosphorylated by AKT on the same serine residues phosphorylated also by AMPK, thus inhibiting its functions. In the absence of insulin or metabolic stress stimuli that activate AMPK, the unphosphorylated protein AS160 stimulates the GTPase activity of Rab, converting it in its inactive GDP-bound form, unable to stimulate the transport of the GLUT4 containing vesicles towards plasma membrane. Thus, the transport of glucose from blood into muscle cells or adipocytes is inhibited. On the contrary, when stress stimuli activate AMPK, or insulin activates AKT, AS160 becomes phosphorylated, and Rab is stabilized in its active GTP-bound form inducing the fusion of the vesicles to plasma membrane [92]. AMPK regulates also the expression of many genes involved in the control of the energetic metabolism. In fact, activated AMPK induces: i) the downregulation of the fatty acid synthase (FAS) expression decreasing the cellular concentration of fatty acid; ii) the decrease of cholesterol synthesis [93-96]; iii) the upregulation of the peroxisome proliferator-activated receptor- $\gamma$ coactivator- $1 \alpha$ expression, which consequently increases the mitochondrial biogenesis [97-99]; iv) the upregulation of the hexokinase II and GLUT4 expression in muscle cells [97]. In addition, AMPK downregulates the expression of both phosphoenolpyruvate carboxykinase (PEPCK) and glucose-6-phosphatase genes in the liver, thereby inhibiting gluconeogenesis [100, 101].

Natural compounds that target AMPK positively influence the insulin signaling contributing: i) to stimulate GLUT4 translocation onto the plasma membrane of adipocyte and muscle cells; ii) to increase GLUT1/4 expression and glucose uptake; iii) to phosphorylate and activate the transcriptional co-activator PPAR $\gamma$ coactivator-1 (PGC $1 \alpha$ ). PGC $1 \alpha$ is one of the most important transcriptional regulator of mitochondrial gene expression and stimulates both the mitochondriogenesis and the mitochondrial oxidative capacity, thereby contributing to fatty acid catabolism. In the liver, natural compounds that target AMPK are able: i) to inhibit 
expression of key players gluconeogenetic enzymes such as phosphoenolpyruvate carboxykinase and glucose-6phosphatase; ii) to inhibit the expression of transcription factors involved in the regulation of lipids synthesis, such as acetyl-CoA carboxylase-1 and fatty acid synthase; iii) to increase fatty acid oxidation, through inactivation of the acetyl CoA carboxylase-2, the enzyme that catalyzed the production of malonyl-CoA, a potent inhibitor of type-1 carnitine acyl tranferase- 1 .

Most of compounds listed in Table 2 were tested in vivo and/or in vitro by using different cellular models, such as muscle and liver cells as well as adipocytes. In vivo experiments performed on diabetic or insulin resistant rats or mice, revealed that compounds such as nobiletin, EGCG, proanthocyanidins, eicosapentaenoic acid, curcumin, berberine, galegine, combrestatin A-4, arctigenin, chlorogenic acid, salicylate, shikonin stimulate and enhance both basal and insulin-mediated glucose transports in muscles, attenuate peripheral insulin resistance induced by FFAs, improve the symptoms of metabolic syndrome induced by fructose richdiet, reduce inflammatory status, contribute to the weight loss and improves glucose tolerance in high-fat diet-induced obese mice, contributing to normalize blood glucose levels. Compelling evidences showed that in vitro, most of these substances (quercetin, glyceollin, ursolic acid, naringenin, retinoic acid, resveratrol, caffeic acid phenethyl ester, isoginkgetin, rutin, $(S)$-(6)-gingerol, astragalus polysaccharide, picetannol, trans-10, cis-12 conjugated linoleic acid, tangeritin, monascin and ankaflavin, capsaicin, isodihydrocapsiate, $\alpha$-sitosterol, salidroside, damulin $\mathrm{A} / \mathrm{B}, \mathrm{p}$-cumarinic acid, cinnamon, osthole, ascofuranone, tanshinone IIA, pinusolide, theasinensins, octaphlorethol A) are able to activate the AMPK enzymes, thereby stimulating GLUT4 translocation and glucose uptake in muscle cells or adipocytes. Furthermore luteolin, S-allyl-cysteine, theaflavins, and genistein are able to influence liver cells metabolism, inhibiting lipids synthesis, reducing lipid storage and improving insulin receptor sensitivity. Finally, additional evidences obtained from in vitro studies showed that other compounds (daidzein, $\beta$-carotene, kaempferol 3-neohesperidoside, kaempferitrin, pongamol, karanjin, pachymic acid, gallic acid, 4hydroxyisoleucine, calophyllic acid and isocalophyllic acid, 4-hydroxypipecolic acid) stimulate GLUT4 expression and/or GLUT4 translocation to plasma membrane, both in adipocytes and muscle cells, contributing to increase the rate of glucose uptake.

\section{PPARs Activation by Natural Agonists Increases Insulin Sensitivity}

Lipid-rich diets can have deleterious effects on human health, favouring a rapid weight gain, insulin resistance and, in most cases, the development of T2DM [102]. Triacylglycerols derived from diet or synthesized by liver are transported in the blood by lipoproteins. The lipoprotein lipase present on the wall of blood vessels hydrolyzes triglycerides contained in the lipoproteins releasing free fatty acids, which are then absorbed by cells. Cellular free fatty acids bind and activate the peroxisome proliferator-activated receptors (PPARs) which, in turn, upregulates the expression of several genes involved in the fatty acid metabolism [103]. Several PPAR isotypes $(\alpha, \beta / \delta$ and $\gamma)$, which are expressed in tissue-specific manner, have been identified. PPAR $\alpha$ is expressed in liver, heart, kidney and skeletal muscle; PPAR $\gamma$ is mainly present in adipocytes, in several kind of immune cells, in the mucosa of colon and cecum, and in placenta, whereas PPAR $\delta$ can be detected in tissues controlling lipid metabolism, such as adipocytes, heart, and skeletal muscle [104]. These receptors act as metabolic sensors and are able to modulate, depending on the nutrient availability, the expression of several genes codifying enzymes involved in the control of energetic metabolism (Fig. 4). For example, in muscle, liver and heart, PPAR $\alpha$ stimulates the transcription of genes involved in fatty oxidation, thereby reprogramming cells to high-capacity fatty acid metabolism [105]. Nevertheless, when the fatty acids availability exceeds the cells oxidative capability, cells undergoes to metabolic overload, resulting in mitochondrial disfunction (Fig. 5) [106]. The presence of mitochondrial abnormalities accompanied by high fatty acid levels in most of muscle and liver cells of subjects affected by insulin resistance or T2DM confirms this hypothesis [107-109]. The excess fatty acids are esterified and either stored or metabolized to various intermediates such as diacylglycerols, ceramides and triglycerides, resulting in a significant accumulation into cytoplasm or endoplasmic reticulum. Diacylglycerols activate the protein kinase $\mathrm{C}$ theta isoform (PKC $\theta$ ) which, in turn, phosphorylates IRS-1 on serine residues, inhibiting its functions. Thus, signaling events downstream insulin receptor, such as the activation of PI3K and AKT, GLUT4 translocation onto the plasma membrane, and glycogen synthesis are impaired. On the other hand, ceramides activate protein kinase $\mathrm{C}$ zeta isoform $(\mathrm{PKC} \xi)$ and protein phosphatase $2 \mathrm{~A}$, which collaborate to inhibit both translocation and activation of AKT onto the plasma membrane, thereby contributing to reduce insulin sensitivity [110]. Finally, accumulation of fatty acids in the endoplasmic reticulum induces a stress condition resulting in the activation of the stress activated Janus kinase (JNK), which phosphorylates IRS-1 [111]. In addition, ER stress contributes to increase PTP1B expression and leads to insulin resistance in muscle cells, suggesting a link between ER stress and the pathogenesis of obesity-associated insulin resistance (Fig. 5) [112]. Hence, the stimulation of PPARs activity is an effective strategy to lower blood lipid levels as well as to increase the insulin sensitivity, overcoming the problem of insulin resistance [113]. In the last decades, several synthetic agonists of PPARs have been produced, but only few of them, such as fibrates (clofibrate, fenofibrate, bezafibrate) and thiazolidinediones (rosiglitazone and pioglitazone) have been approved for treatment of T2DM and metabolic syndrome. Thiazolidinediones show antidiabetic activity in patients affected by T2DM, since they increase insulin sensitivity, stimulate glucose uptake, and decrease the levels of insulin and glycated hemoglobin. The efficacy of PPAR $\gamma$ agonists is in part attributable to reduction of lipotoxicity in skeletal muscle and liver, and in part is probably due to their ability to stimulate the expression of glucose transporters GLUT1 and GLUT4 or of other intracellular proteins such as c-Cbl-associated protein (CAP) [114, 115]. Furthermore, it has been demonstrated that PPAR $\gamma$ agonists are able to stimulate adiponectin expression, which, in turn, increases fatty acid oxidation through an AMPK-dependent mechanism in liver and muscle, and decreases glucose production in liver [116]. In addition, PPAR $\delta$ activation correlates with 
Table 2. Natural substances that increase glucose uptake acting through the AMPK activation.

\begin{tabular}{|c|c|c|}
\hline Compound & Main Biological Effects & Source \\
\hline $\begin{array}{l}\text { Quercetin and quercetin gly- } \\
\text { cosides }\end{array}$ & Stimulation of AMPK and glucose uptake in muscle cells [186] & Vaccinium vitis-idaea \\
\hline Glyceollin & $\begin{array}{l}\text { Enhancement of insulin sensitivity in } \mathrm{db} / \mathrm{db} \text { mice muscle under ER stress condi- } \\
\text { tions through activation of AMPK [187] }\end{array}$ & $\begin{array}{l}\text { Derived from daidzein in soybeans in- } \\
\text { fected by fungi }\end{array}$ \\
\hline Luteolin & Activation of AMPK in HepG2 cells [188] & Several plant species \\
\hline S-allyl cysteine & Activation of AMPK through $\mathrm{Ca}^{2+} /$ calmodulin-dependent kinase kinase [189] & Allium sativum \\
\hline Nobiletin & $\begin{array}{c}\text { Increase of phospho-Akt and GLUT1 and GLUT4 expression in white adipose } \\
\text { tissue and muscle [190]; Increase of hepatic and peripheral insulin sensitivity } \\
{[191]}\end{array}$ & Fruits of Citrus species \\
\hline Ursolic acid & Activation of LKB1/AMPK pathway [192] & Several plant species \\
\hline Epigallocatechin gallate (EGCG) & $\begin{array}{l}\text { Attenuation of peripheral insulin resistance through AMPK pathway in vivo } \\
\text { [193]; activation of IRS2 and AMPK signaling in rat pancreatic } \beta \text {-cells [194]; } \\
\text { activation of the LKB1/AMPK pathway [195]; suppression of hepatic glu- } \\
\text { coneogenesis through the AMPK [196] }\end{array}$ & Camellia sinensis \\
\hline Theaflavins & Decrease of hepatic lipid accumulation trough the LKB1/AMPK pathway [197] & Several species of tea (leaves) \\
\hline Naringenin & Increases muscle cell glucose uptake via AMPK [198] & Citrus paradisi \\
\hline Genistein & $\begin{array}{l}\text { Activation of PGC-1 } \alpha \text {, upregulation of GLUT1 expression. Reversion of free } \\
\text { fatty acid-induced insulin resistance in HepG } 2 \text { hepatocytes through targeting } \\
\text { JNK [199] }\end{array}$ & Flemingia vestita \\
\hline Daidzein & $\begin{array}{l}\text { Enhancement of insulin-stimulated glucose uptake in adipocytes by increasing } \\
\text { the expression of GLUT4 and IRS1 via the activation of PPAR } \gamma \text { [200] }\end{array}$ & Some plant and herb species \\
\hline Proanthocyanidin-rich extract & Enhancement of IRS1 and GLUT4 expression [201] & Malus domestica \\
\hline Retinoic acid & Activation of AMPK in skeletal muscle cells [202] & Vegetables fonts (vitamin A metabolite) \\
\hline Eicosapentaenoic acid & $\begin{array}{l}\text { Increase of GLUT4 expession in muscle and 2-deoxy-D-glucose uptake in } \\
\qquad \text { C2C12 myotubes [203] }\end{array}$ & Vegetable and fish fonts \\
\hline Curcumin & Activation of LKB1/AMPK pathway [204] & Curcuma longa \\
\hline Resveratrol & Activation of PGC- $1 \alpha$ and AMPK [205] & Fruiting berry of Vitis vinifera \\
\hline Caffeic acid phenethyl ester & Activation of AMPK in skeletal muscle [206] & Several plants and honey \\
\hline Berberine & Activation of AMPK [207]; [208] & $\begin{array}{l}\text { Several Berberis species and a variety of } \\
\text { other plant species }\end{array}$ \\
\hline Isoginkgetin & Enhances adiponectin secretion through AMPK activation [209] & Ginkgo biloba \\
\hline Galegine & $\begin{array}{l}\text { Activation of AMPK. Stimulation of glucose uptake in adipocytes and L6 myo- } \\
\text { tubes }[210]\end{array}$ & Galega officinalis \\
\hline$\beta$-carotene & $\begin{array}{l}\text { Enhance the expression of genes related to insulin sensitivity, including GLUT4 } \\
\text { and adiponectin [211]. Decrease blood glucose [212] }\end{array}$ & Daucus carota and other plant species \\
\hline Rutin & $\begin{array}{l}\text { Increase of glucose uptake in rat soleus muscle, enhancing GLUT4 synthesis } \\
\text { and translocation [213] }\end{array}$ & Ginkgo biloba and other plant species \\
\hline Kaempferol 3-neohesperidoside & $\begin{array}{c}\text { Stimulation of glucose uptake in the rat soleus muscle via the PI3K and PKC } \\
\text { pathways, and of the synthesis of new glucose transporters [214] }\end{array}$ & Several plant species \\
\hline Kaempferitrin & $\begin{array}{l}\text { Activation of the classical insulin transduction pathway in adipocytes. Increased } \\
\text { expression and translocation of GLUT4 to the membrane [215] }\end{array}$ & Leaves of various plant species \\
\hline (S)-(6)-Gingerol & Enhancement glucose uptake in L6 myotubes by activation of AMPK [216] & Zingiber officinale \\
\hline
\end{tabular}


(Table 2) contd....

\begin{tabular}{|c|c|c|}
\hline Compound & Main Biological Effects & Source \\
\hline Astragalus polysaccharide & $\begin{array}{l}\text { Stimulation of glucose uptake in L6 myotubes through the AMP-AMPK-AS160 } \\
\text { pathway [217] }\end{array}$ & Astragalus membranaceus \\
\hline Picetannol & $\begin{array}{l}\text { Promotion of glucose uptake, AMPK phosphorylation and GLUT4 transloca- } \\
\text { tion in L6 myotubes [218] }\end{array}$ & Picea abies \\
\hline Tangeritin & $\begin{array}{l}\text { Stimulation of glucose uptake via the AMPK signaling pathways in } \mathrm{C} 2 \mathrm{C} 12 \\
\text { myotubes [221] }\end{array}$ & Fruits of Citrus species \\
\hline Monascin and ankaflavin & Activation of AMPK in mice [222] & Monascus purpureus \\
\hline$\beta$-sitosterol & Activation of AMPK in L6 myotubes [226] & Several plant species \\
\hline Salidroside & $\begin{array}{l}\text { Stimulation of glucose uptake in skeletal muscle cells by activation of AMPK } \\
\text { [227] }\end{array}$ & Rhodiola rosea \\
\hline Damulin A/B & Activation of AMPK in L6 myotube cells [228] & Gynostemma pentaphyllum \\
\hline p-Coumaric acid & Activation of AMPK in L6 skeletal muscle cells [229] & A variety of edible plants \\
\hline Arctigenin & Activation of AMPK in ob/ob mice [230] & Asteraceae \\
\hline Chlorogenic acid & Stimulation of glucose transport in skeletal muscle via AMPK activation [231 ] & Several plant species \\
\hline Pongamol & $\begin{array}{l}\text { Stimulation of both glucose transport and GLUT4 translocation to the cell sur- } \\
\text { face of L6 myotubes [236] }\end{array}$ & Pongamia pinnata \\
\hline Karanjin & $\begin{array}{l}\text { Increase in glucose uptake in L6 myotubes and translocation of GLUT4 to } \\
\text { plasma membrane associated with activation of AMPK pathway [237] }\end{array}$ & Pongamia pinnata \\
\hline Pachymic acid & $\begin{array}{l}\text { Stimulation of glucose uptake and GLUT4 expression and translocation in } \\
\text { adipocytes. Both PI3K and AMPK are involved in the above actions [238] }\end{array}$ & Poria cocos \\
\hline Gallic acid & Stimulation of glucose uptake and GLUT4 translocation in 3T3-L1 cells [239] & Hippophae rhamnoides \\
\hline 4-hydroxyisoleucine & $\begin{array}{c}\text { Stimulation of glucose uptake and GLUT4 translocation in skeletal muscle cells } \\
\text { in a PI3K/AKT-dependent mechanism [240] }\end{array}$ & Trigonella foenum-graecum \\
\hline $\begin{array}{c}\text { Calophyllic acid and isocalo- } \\
\text { phyllic acid }\end{array}$ & $\begin{array}{c}\text { Stimulation of glucose uptake and GLUT4 translocation in L6 myotubes } \\
\text { through PI3K- and EKR1/2-dependent mechanisms (independent to the AMPK } \\
\text { activation [241] }\end{array}$ & Calophyllum inophyllum \\
\hline 4-hydroxypipecolic acid & $\begin{array}{l}\text { Stimulation of both glucose uptake and GLUT4 translocation to cell surface in } \\
\text { skeletal muscle cells [242] }\end{array}$ & Peganum harmala Linn \\
\hline Ascofuranone & AMPK activation in L6 myotube cells [243] & Ascochyta viciae \\
\hline Tanshinone IIA & $\begin{array}{l}\text { AMPK activation in L6 myotubes and reduction of blood glucose levels in } \\
\qquad \mathrm{db} / \mathrm{db} \text { mice [244] }\end{array}$ & Salvia miltiorrhiza bunge \\
\hline
\end{tabular}


(Table 2) contd....

\begin{tabular}{|c|c|c|}
\hline Compound & Main Biological Effects & Source \\
\hline Pinusolide & $\begin{array}{l}\text { Enhancement of IRS-1 tyrosine phosphorylation by the activating the AMPK } \\
\text { pathway in muscle cells [245] }\end{array}$ & Biota orientalis \\
\hline Theasinensins & $\begin{array}{l}\text { Stimulation of glucose uptake through the AMPK pathway in rat skeletal mus- } \\
\text { cle cells [246] }\end{array}$ & Camellia sinensis \\
\hline Octaphlorethol A & $\begin{array}{l}\text { Increase of both GLUT4 translocation to the plasma membrane and glucose } \\
\text { uptake trough Akt and AMPK activation in differentiated L6 rat myoblast cells } \\
\text { [247] }\end{array}$ & Ishige foliacea \\
\hline Shikonin & $\begin{array}{l}\text { Shikonin increases glucose uptake in skeletal muscle cells via an insulin- } \\
\text { independent pathway dependent on calcium [248] }\end{array}$ & Lithospermum erythro \\
\hline
\end{tabular}

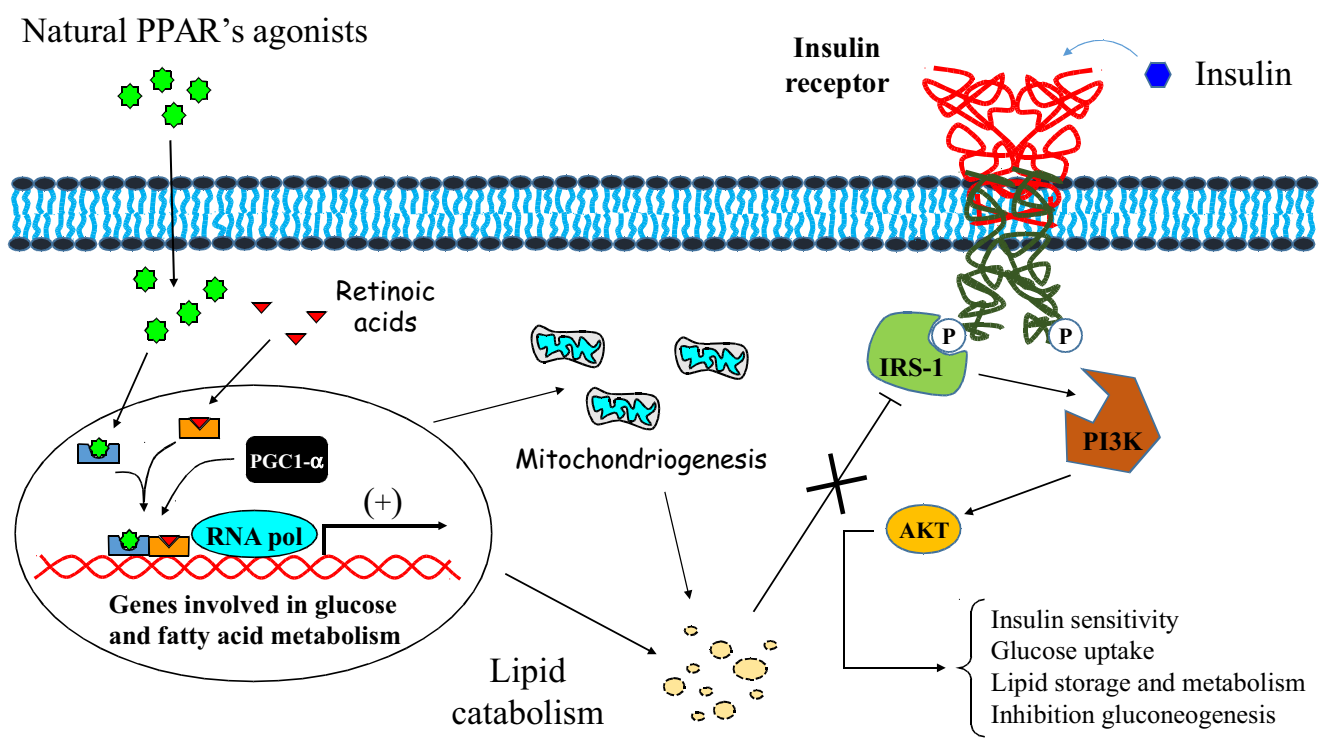

Fig. (4). Activation of PPARs by natural agonists increase insulin sensitivity. Several natural compounds, mimicking natural agonist, bind PPARs and stimulate their transcriptional activity. Consequently, the expression of several genes involved in lipids metabolism, such as those involved in fatty acid and glucose transport, $\beta$-oxidation, mitochondrial respiration and biogenesis, is strongly increased. Activation of PPARs favors adipocyte differentiation and lipid storage in the subcutaneous adipose tissue, thereby decreasing the levels of blood fatty acids. In addition, natural PPARs agonists reduce the release of inflammatory cytokines from visceral adipose tissue, thus inhibiting JNK activation in the peripheral tissues such as liver and muscle. The increase of lipid metabolism leads to reduction of intracellular depots, downregulating the activity of $\mathrm{PKC} \theta, \mathrm{PKC} \zeta$ and PP2A, thereby resulting in an increase of insulin sensitivity. The decrease of fatty acid levels in the hepatocytes and muscle cells alleviates ER stress, leading to downregulation of PTP1B expression and improving the insulin signaling pathway. For an explanation of acronyms see 'Abbreviations'.

expression of genes involved in fatty acid oxidation or/and with expression of uncoupling proteins in brown adipose tissue and in skeletal muscle $[117,118]$. Compelling evidences demonstrated that in muscle cells PPAR $\delta$ agonists stimulate glucose uptake through an AMPK and/or p38MAPK-dependent signaling pathways, and that they are able to decrease glucose production in the liver $[119,120]$.

Although the known efficacy of the commercially available PPARs agonists, these drugs have adverse effects in humans, hence the research in this field is still very active. In the last years it has been demonstrated that many natural compounds are able to act as agonist of PPARs, contributing to stimulate insulin activity, glucose uptake and fatty acid metabolism, both in vitro and in vivo. In Table 3 most of known natural agonists of PPARs are listed.

\section{CONCLUSION}

Nowadays, the tendency to a sedentary lifestyle and obesity are becoming a serious problem in many western countries. Epidemiological analysis show that a growing number of individuals suffer of systemic insulin resistance, T2DM and/or metabolic syndrome. Drugs currently available to counteract these diseases are often characterized by a low effectiveness, unexpected side effects and ido not provide adequate protection against the many complications of these diseases. Many studies demonstrated that natural dietary compounds exert beneficial effects on human health, improving insulin signaling pathway and contributing to a better control of energy homeostasis, both in health humans that in diabetic subjects. For this reason many researches agree that assumption of natural bioactive compounds could be an 


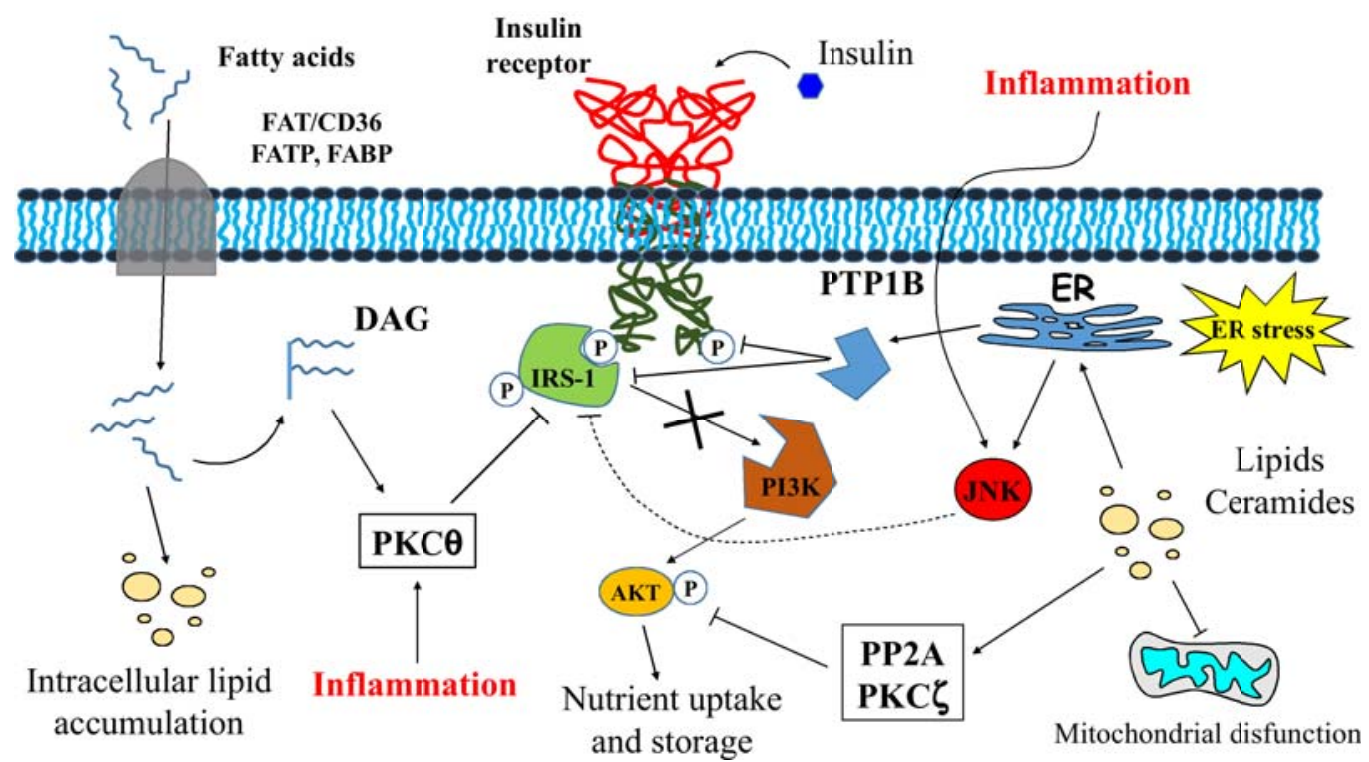

Fig. (5). Intracellular lipid overload leads to impaired insulin signaling. Intracellular lipid accumulation stimulates PKC $\theta$ activation that inhibits IRSs. Similarly, ceramides stimulate PKC $\zeta$ and PP2A activation, decreasing activity of AKT. On the other hand, excessive storage of lipids into endoplasmic reticulum trigger stress response that leads to activation of JNK which increase serine phosphorylation of IRS-1, impairing insulin signaling. JNK is also activated by inflammatory cytokines, suggesting a link between obesity, chronic inflammation and insulin resistance. ER stress causes elevation in PTP1B levels, which targets IR and IRS-1, decreasing insulin sensitivity.

Table 3. Natural agonists of PPARs.

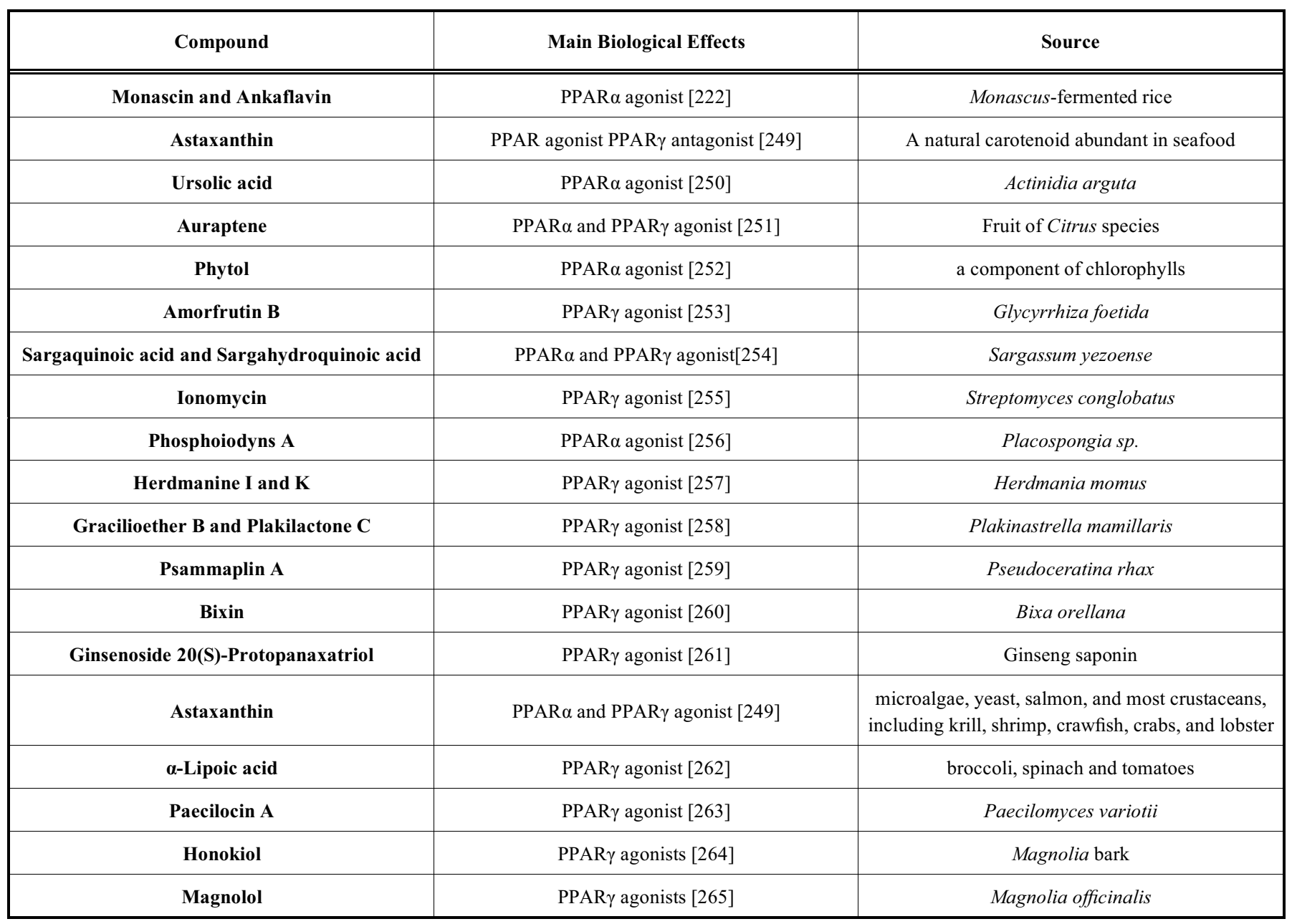


(Table 3) contd....

\begin{tabular}{|c|c|c|}
\hline Emodin & PPAR $\gamma$ agonists [266] & Rheum palmatum $L$ \\
\hline Daidzein & PPAR $\gamma$ agonists [200] & Soy and other plant and herb species \\
\hline Artepillin C & PPAR $\gamma$ agonists [268] & Baccharis dracunculifolia \\
\hline Ankaflavin & PPAR $\gamma$ agonist [270] & Monascus-fermented rice \\
\hline Amorphastilbol & PPAR $\alpha$, PPAR $\gamma$ agonist [271] & Amorpha fruticosa \\
\hline Luteolin & PPAR $\gamma$ agonist [272] & Several plant species \\
\hline Apigenin & PPAR $\alpha$ and PPAR $\gamma$ agonist [274] & Several plants \\
\hline Acacetin & PPAR $\alpha$ and PPAR $\gamma$ agonist [274] & $\begin{array}{c}\text { Robinia pseudoacacia, Turnera diffusa, Asplenium } \\
\text { normale }\end{array}$ \\
\hline Chrysoeriol & PPAR $\alpha$ and PPAR $\gamma$ agonist [274] & Artemisia copa \\
\hline Diosmetin & $\operatorname{PPAR} \alpha$ and PPAR $\gamma$ agonist [274] & Caucasian vetch plants \\
\hline Chrysin & PPAR $\alpha$ and PPAR $\gamma$ agonist [274] & Several plants \\
\hline Kaempferol & PPAR $\alpha$ and PPAR $\gamma$ agonist [274] & Several plants \\
\hline Catalposide & PPAR $\alpha$ agonist [275] & Catalpa ovata \\
\hline Hesperidin & PPAR $\gamma$ agonist [277 ] & Citrus fruits \\
\hline
\end{tabular}

effective strategy to prevent the onset and diffusion of chronic degenerative diseases such as T2DM. Traditional medicines, and in particular traditional Chinese medicine, use several plants preparations to treat diabetes and diabetic complications without side-effects. These herbal preparations contain tens of constituents, whose formulation is not standardizable. Thus in the last decades many efforts have been made attempting to identify compounds inside these preparation responsible for the hypoglycaemic effect. For example, metformin, a widely used hypoglycaemic drug, was purified from the traditional preparation of Galega officinalis. Several natural compounds have been shown to modulate the activity of specific enzymes and/or signaling molecules involved in the glycaemic control. Some of these compounds are in trial III phase to confirm their actual effectiveness on humans.

\section{ABBREVIATIONS}
ADP
$=$ Adenosine diphosphate
$\mathrm{Akt} / \mathrm{PKB}=$ Protein kinase $\mathrm{B}$

AMPK

AS160

$=\mathrm{AMP}$-activated protein kinase

ATP

CAP

CD45

$\mathrm{CHO} / \mathrm{hIR}=$ Chinese hamster ovary cell transfected with insulin receptor gene

DAG $\quad=$ Diacylglycerol

$\mathrm{DM} \quad=$ Diabetes mellitus

EGFR $=$ Epidermal growth factor receptor

ER $=$ Endoplasmic reticulum

ERK $=$ Extracellular signal-regulated kinase

ERK $=$ extracellular signal-regulated kinases

FABP $=$ Fatty acid binding protein 
FAT $/$ CD36 $=$ Fatty acid transporter

FATP $=$ Fatty acid transport proteins

FOXO $=$ Forkhead transcription factors

GAP $=$ GTPase activating protein

GLUT4 $=$ Glucose transporter type 4

Grb2 = Growth factor receptor-bound protein 2

GS $=$ Glycogen synthase

GSK3 = Glycogen synthase kinase 3

HepG2 = Human hepatocellular liver carcinoma cell line

IR $=$ Insulin receptor

IRS $=$ Insulin receptor substrate

JNK $=$ c-Jun N-terminal kinases

JNK $=$ Jun N-terminal kinase

LAR $=$ Leucocyte antigen related phosphatase

LMW-PTP $=$ Low Molecular Weight Protein Tyrosine Phosphatase

MAPK $=$ Mitogen activated protein kinases

MptpB = Mycobacterium tuberculosis Protein Tyrosine Phosphatases

p70S6K = Ribosomal protein S6 kinase beta-1

PDE $=$ Phosphodiesterase

PDGFR $=$ Platelet derived growth factor receptor

PDK1 = Phosphoinositide-dependent kinase 1

PEPCK = Phosphoenolpyruvate carboxykinase

PGC $=$ Peroxisome proliferator-activated receptor gamma coactivator

PI3K = Phosphatidylinositol 3-kinase

PIP3 = Phosphatidylinositol (3,4,5)-triphosphate

$\mathrm{PKC}=$ Protein kinase $\mathrm{C}$

$\mathrm{PKD}=$ Protein kinase $\mathrm{D}$

PPAR $=$ Peroxisome proliferator-activated receptors

PTP1B $=$ Protein Tyrosine Phophatases 1B

PTPs $=$ Protein Tyrosine Phophatases

SHC $=$ Src homology 2 domain containing) transforming protein

SHP-2 = Src homology-2 domain-containing phosphatase

SOS $\quad=$ Son of sevenless

SREB1 $=$ Sterol regulatory element-binding protein 1

STAT3 = Signal transducer and activator of transcription 3

T2DM $=$ Type 2 diabetes mellitus

TC-PTP $=$ T-Cell Protein Tyrosine Phosphatase

TORC1 $1=$ Transcriptional coactivator for CREB1

\section{CONFLICT OF INTEREST}

The authors confirm that this article content has no conflict of interest.

\section{ACKNOWLEDGEMENTS}

Declared none.

\section{REFERENCES}

[1] Taniguchi, C.M.; Emanuelli, B.; Kahn, C.R. Critical nodes in signalling pathways: insights into insulin action. Nat. Rev. Mol. Cell Biol., 2006, 7, 85-96.

[2] Shaw, J.E.; Sicree, R.A.; Zimmet, P.Z. Global estimates of the prevalence of diabetes for 2010 and 2030. Diabetes Res. Clin. Pract., 2009, 87, 4-14.

[3] Kleinman, P.H.; Goldsmith, D.S.; Friedman, S.R.; Hopkins, W ; Des Jarlais, D.C. Knowledge about and behaviors affecting the spread of AIDS: a street survey of intravenous drug users and their associates in New York City. Int. J. Addict., 1990, 25, 345-361.

[4] Demont, F.; Borderon, J.C.; Bloc, D.; Saliba, E.; Gold, F.; Laugier, J. [Guidelines for antibiotic therapy in an infectious risk unit]. $\mathrm{Pe}$ diatrie, 1985, 40, 363-373.

[5] Kahn, S.E.; Hull, R.L.; Utzschneider, K.M. Mechanisms linking obesity to insulin resistance and type 2 diabetes. Nature, 2006, 444, 840-846.

[6] Paschou, S.A.; Leslie, R.D. Personalizing guidelines for diabetes management: twilight or dawn of the expert? BMC Med., 2013, 11, 161.

[7] Hui, H.; Tang, G.; Go, V.L. Hypoglycemic herbs and their action mechanisms. Chin. Med., 2009, 4, 11.

[8] Patel, D.; Prasad, S.; Kumar, R.; Hemalatha, S. An overview on antidiabetic medicinal plants having insulin mimetic property. Asian Pac. J. Trop. Biomed., 2013, 2, 320-330.

[9] Babu, P.V.; Liu, D.; Gilbert, E.R. Recent advances in understanding the anti-diabetic actions of dietary flavonoids. J. Nutr. Biochem., 2013, 24, 1777-1789.

[10] Perera, P.K.; Li, Y. Functional herbal food ingredients used in type 2 diabetes mellitus. Pharmacogn. Rev., 2012, 6, 37-45.

[11] van Dam, R.M.; Naidoo, N.; Landberg, R. Dietary flavonoids and the development of type 2 diabetes and cardiovascular diseases: review of recent findings. Curr. Opin. Lipidol., 2012, 24, 25-33.

[12] Bahadoran, Z.; Mirmiran, P.; Azizi, F. Dietary polyphenols as potential nutraceuticals in management of diabetes: a review. $J$. Diabetes Metab. Disord., 2013, 12, 43.

[13] Liu, Y.J.; Zhan, J.; Liu, X.L.; Wang, Y.; Ji, J.; He, Q.Q. Dietary flavonoids intake and risk of type 2 diabetes: a meta-analysis of prospective cohort studies. Clin. Nutr., 2013, 33, 59-63.

[14] Xiao, J.; Ni, X.; Kai, G.; Chen, X. A review on structure-activity relationship of dietary polyphenols inhibiting $\alpha$-amylase. Crit. Rev. Food Sci. Nutr., 2013, 53, 497-506.

[15] Xiao, J.; Kai, G.; Yamamoto, K.; Chen, X. Advance in dietary polyphenols as $\alpha$-glucosidases inhibitors: a review on structureactivity relationship aspect. Crit. Rev. Food Sci. Nutr., 2013, 53, 818-836.

[16] Anhê, F.F.; Desjardins, Y.; Pilon, G.; Dudonne, S.; Genovese, M.I.; Franco, M.; Lajolo, F.M.; Marette, A. Polyphenols and type 2 diabetes: A prospective review. PharmaNutrition, 2013, 1, 105-114.

[17] Xiao, J.; Högger, P. Influence of diabetes on the pharmacokinetic behavior of natural polyphenols. Curr. Drug Metab., 2013, 15, 2329.

[18] Zhang, B.; Salituro, G.; Szalkowski, D.; Li, Z.; Zhang, Y.; Royo, I.; Vilella, D.; Díez, M.T.; Pelaez, F.; Ruby, C.; Kendall, R.L.; Mao, X.; Griffin, P.; Calaycay, J.; Zierath, J.R.; Heck, J.V.; Smith, R.G.; Moller, D.E. Discovery of a small molecule insulin mimetic with antidiabetic activity in mice. Science, 1999, 284, 974-977.

[19] Li, Y.; Kim, J.; Li, J.; Liu, F.; Liu, X.; Himmeldirk, K.; Ren, Y.; Wagner, T.E.; Chen, X. Natural anti-diabetic compound 1,2,3,4,6penta-O-galloyl-D-glucopyranose binds to insulin receptor and activates insulin-mediated glucose transport signaling pathway. Biochem. Biophys. Res. Commun., 2005, 336, 430-437.

[20] Diesel, B.; Kulhanek-Heinze, S.; Höltje, M.; Brandt, B.; Höltje, H.D.; Vollmar, A.M.; Kiemer, A.K. Alpha-lipoic acid as a directly 
binding activator of the insulin receptor: protection from hepatocyte apoptosis. Biochemistry, 2007, 46, 2146-2155.

[21] Weber, M.A.; Lidor, A.; Arora, S.; Salituro, G.M.; Zhang, B.B.; Sidawy, A.N. A novel insulin mimetic without a proliferative effect on vascular smooth muscle cells. J. Vasc. Surg., 2000, 32, 11181126.

[22] Qureshi, S.A.; Ding, V.; Li, Z.; Szalkowski, D.; Biazzo-Ashnault, D.E.; Xie, D.; Saperstein, R.; Brady, E.; Huskey, S.; Shen, X.; Liu, K.; Xu, L.; Salituro, G.M.; Heck, J.V.; Moller, D.E.; Jones, A.B.; Zhang, B.B. Activation of insulin signal transduction pathway and anti-diabetic activity of small molecule insulin receptor activators. J. Biol. Chem., 2000, 275, 36590-36595.

[23] Tiganis, T.; PTP1B and TCPTP--nonredundant phosphatases in insulin signaling and glucose homeostasis. FEBS J., 2012, 280, 445-458.

[24] Koren, S.; Fantus, I.G. Inhibition of the protein tyrosine phosphatase PTP1B: potential therapy for obesity, insulin resistance and type-2 diabetes mellitus. Best Pract. Res. Clin. Endocrinol. Metab., 2007, 21, 621-640.

[25] Ahmad, F.; Goldstein, B.J. Functional association between the insulin receptor and the transmembrane protein-tyrosine phosphatase LAR in intact cells. J. Biol. Chem., 1997, 272, 448-457.

[26] Zhang, W.R.; Li, P.M.; Oswald, M.A.; Goldstein, B.J. Modulation of insulin signal transduction by eutopic overexpression of the receptor-type protein-tyrosine phosphatase LAR. Mol. Endocrinol., 1996, 10, 575-584.

[27] Li, P.M.; Zhang, W.R.; Goldstein, B.J. Suppression of insulin receptor activation by overexpression of the protein-tyrosine phosphatase LAR in hepatoma cells. Cell. Signal., 1996, 8, 467-473.

[28] Kulas, D.T.; Goldstein, B.J.; Mooney, R.A. The transmembrane protein-tyrosine phosphatase LAR modulates signaling by multiple receptor tyrosine kinases. J. Biol. Chem., 1996, 271, 748-754.

[29] Ren, J.M.; Li, P.M.; Zhang, W.R.; Sweet, L.J.; Cline, G.; Shulman, G.I.; Livingston, J.N.; Goldstein, B.J. Transgenic mice deficient in the LAR protein-tyrosine phosphatase exhibit profound defects in glucose homeostasis. Diabetes, 1998, 47, 493-497.

[30] Møller, N.P.; Møller, K.B.; Lammers, R.; Kharitonenkov, A.; Hoppe, E.; Wiberg, F.C.; Sures, I.; Ullrich, A. Selective downregulation of the insulin receptor signal by protein-tyrosine phosphatases alpha and epsilon. J. Biol. Chem., 1995, 270, 2312623131.

[31] Lammers, R.; MÃ,Å,ler, N.P.; Ullrich, A. The transmembrane protein tyrosine phosphatase alpha dephosphorylates the insulin receptor in intact cells. FEBS Lett., 1997, 404, 37-40.

[32] Cong, L.N.; Chen, H.; Li, Y.; Lin, C.H.; Sap, J.; Quon, M.J. Overexpression of protein tyrosine phosphatase-alpha (PTP-alpha) but not PTP-kappa inhibits translocation of GLUT4 in rat adipose cells. Biochem. Biophys. Res. Commun., 1999, 255, 200-207.

[33] Arnott, C.H.; Sale, E.M.; Miller, J.; Sale, G.J. Use of an antisense strategy to dissect the signaling role of protein-tyrosine phosphatase alpha. J. Biol. Chem., 1999, 274, 26105-26112.

[34] Le, H.T.; Ponniah, S.; Pallen, C.J. Insulin signaling and glucose homeostasis in mice lacking protein tyrosine phosphatase alpha. Biochem. Biophys. Res. Commun., 2004, 314, 321-329.

[35] Rocchi, S.; Tartare-Deckert, S.; Sawka-Verhelle, D.; Gamha, A.; van Obberghen, E. Interaction of SH2-containing protein tyrosine phosphatase 2 with the insulin receptor and the insulin-like growth factor-I receptor: studies of the domains involved using the yeast two-hybrid system. Endocrinology, 1996, 137, 4944-4952.

[36] Tenev, T.; Keilhack, H.; Tomic, S.; Stoyanov, B.; Stein-Gerlach, M.; Lammers, R.; Krivtsov, A.V.; Ullrich, A.; Böhmer, F.D. Both $\mathrm{SH} 2$ domains are involved in interaction of SHP-1 with the epidermal growth factor receptor but cannot confer receptor-directed activity to SHP-1/SHP-2 chimera. J. Biol. Chem., 1997, 272, 59665973.

[37] Hayashi, K.; Shibata, K.; Morita, T.; Iwasaki, K.; Watanabe, M.; Sobue, K. Insulin receptor substrate-1/SHP-2 interaction, a phenotype-dependent switching machinery of insulin-like growth factor-I signaling in vascular smooth muscle cells. J. Biol. Chem., 2004, 279, 40807-40818.

[38] Fukunaga, K.; Noguchi, T.; Takeda, H.; Matozaki, T.; Hayashi, Y.; Itoh, H.; Kasuga, M. Requirement for protein-tyrosine phosphatase SHP-2 in insulin-induced activation of c-Jun $\mathrm{NH}(2)$-terminal kinase. J. Biol. Chem., 2000, 275, 5208-5213.
[39] Chen, H.; Wertheimer, S.J.; Lin, C.H.; Katz, S.L.; Amrein, K.E.; Burn, P.; Quon, M.J. Protein-tyrosine phosphatases PTP1B and syp are modulators of insulin-stimulated translocation of GLUT4 in transfected rat adipose cells. J. Biol. Chem., 1997, 272, 8026-8031.

[40] Clemmons, D.R.; Maile, L.A. Minireview: Integral membrane proteins that function coordinately with the insulin-like growth factor I receptor to regulate intracellular signaling. Endocrinology, 2003, 144, 1664-1670.

[41] Arrandale, J.M.; Gore-Willse, A.; Rocks, S.; Ren, J.M.; Zhu, J. Davis, A.; Livingston, J.N.; Rabin, D.U. Insulin signaling in mice expressing reduced levels of Syp. J. Biol. Chem., 1996, 271, 21353-21358.

[42] Maegawa, H.; Hasegawa, M.; Sugai, S.; Obata, T.; Ugi, S.; Morino, K.; Egawa, K.; Fujita, T.; Sakamoto, T.; Nishio, Y.; Kojima, H.; Haneda, M.; Yasuda, H.; Kikkawa, R.; Kashiwagi, A. Expression of a dominant negative SHP-2 in transgenic mice induces insulin resistance. J. Biol. Chem., 1999, 274, 30236-30243.

[43] Wälchli, S.; Curchod, M.L.; Gobert, R.P.; Arkinstall, S.; Hooft van Huijsduijnen, R. Identification of tyrosine phosphatases that dephosphorylate the insulin receptor. A brute force approach based on "substrate-trapping" mutants. J. Biol. Chem., 2000, 275, 97929796.

[44] Galic, S.; Klingler-Hoffmann, M.; Fodero-Tavoletti, M.T.; Puryer, M.A.; Meng, T.C.; Tonks, N.K.; Tiganis, T. Regulation of insulin receptor signaling by the protein tyrosine phosphatase TCPTP Mol. Cell. Biol., 2003, 23, 2096-2108.

[45] Andersen, J.N.; Elson, A.; Lammers, R.; Rømer, J.; Clausen, J.T.; Møller, K.B.; Møller, N.P. Comparative study of protein tyrosine phosphatase-epsilon isoforms: membrane localization confers specificity in cellular signalling. Biochem. J., 2001, 354, 581-590.

[46] Chiarugi, P.; Cirri, P.; Marra, F.; Raugei, G.; Camici, G.; Manao, G.; Ramponi, G. LMW-PTP is a negative regulator of insulinmediated mitotic and metabolic signalling. Biochem. Biophys. Res. Commun., 1997, 238, 676-682.

[47] Pandey, S.K.; Yu, X.X.; Watts, L.M.; Michael, M.D.; Sloop, K.W.; Rivard, A.R.; Leedom, T.A.; Manchem, V.P.; Samadzadeh, L.; McKay, R.A.; Monia, B.P.; Bhanot, S. Reduction of low molecular weight protein-tyrosine phosphatase expression improves hyperglycemia and insulin sensitivity in obese mice. J. Biol. Chem., 2007, 282, 14291-14299.

[48] Cho, C.Y.; Koo, S.H.; Wang, Y.; Callaway, S.; Hedrick, S.; Mak, P.A.; Orth, A.P.; Peters, E.C.; Saez, E.; Montminy, M.; Schultz, P.G.; Chanda, S.K. Identification of the tyrosine phosphatase PTPMEG2 as an antagonist of hepatic insulin signaling. Cell Metab., 2006, 3, 367-378.

[49] Elchebly, M.; Payette, P.; Michaliszyn, E.; Cromlish, W.; Collins, S.; Loy, A.L.; Normandin, D.; Cheng, A.; Himms-Hagen, J.; Chan, C.C.; Ramachandran, C.; Gresser, M.J.; Tremblay, M.L.; Kennedy, B.P. Increased insulin sensitivity and obesity resistance in mice lacking the protein tyrosine phosphatase-1B gene. Science, 1999, $283,1544-1548$.

[50] Klaman, L.D.; Boss, O.; Peroni, O.D.; Kim, J.K.; Martino, J.L.; Zabolotny, J.M.; Moghal, N.; Lubkin, M.; Kim, Y.B.; Sharpe, A.H.; Stricker-Krongrad, A.; Shulman, G.I.; Neel, B.G.; Kahn, B.B. Increased energy expenditure, decreased adiposity, and tissuespecific insulin sensitivity in protein-tyrosine phosphatase 1Bdeficient mice. Mol. Cell. Biol., 2000, 20, 5479-5489.

[51] Haj, F.G.; Zabolotny, J.M.; Kim, Y.B.; Kahn, B.B.; Neel, B.G. Liver-specific protein-tyrosine phosphatase 1B (PTP1B) reexpression alters glucose homeostasis of PTP1B-/-mice. J. Biol. Chem., 2005, 280, 15038-15046.

[52] Delibegovic, M.; Zimmer, D.; Kauffman, C.; Rak, K.; Hong, E.G.; Cho, Y.R.; Kim, J.K.; Kahn, B.B.; Neel, B.G.; Bence, K.K. Liverspecific deletion of protein-tyrosine phosphatase 1B (PTP1B) improves metabolic syndrome and attenuates diet-induced endoplasmic reticulum stress. Diabetes, 2008, 58, 590-599.

[53] Wang, N.; Zhang, D.; Mao, X.; Zou, F.; Jin, H.; Ouyang, J. Astragalus polysaccharides decreased the expression of PTP1B through relieving ER stress induced activation of ATF6 in a rat model of type 2 diabetes. Mol. Cell. Endocrinol., 2009, 307, 89-98.

[54] Zinker, B.A.; Rondinone, C.M.; Trevillyan, J.M.; Gum, R.J.; Clampit, J.E.; Waring, J.F.; Xie, N.; Wilcox, D.; Jacobson, P.; Frost, L.; Kroeger, P.E.; Reilly, R.M.; Koterski, S.; Opgenorth, T.J.; Ulrich, R.G.; Crosby, S.; Butler, M.; Murray, S.F.; McKay, R.A.; Bhanot, S.; Monia, B.P.; Jirousek, M.R. PTP1B antisense 
oligonucleotide lowers PTP1B protein, normalizes blood glucose, and improves insulin sensitivity in diabetic mice. Proc. Natl. Acad. Sci. U.S.A., 2002, 99, 11357-11362.

[55] Puius, Y.A.; Zhao, Y.; Sullivan, M.; Lawrence, D.S.; Almo, S.C.; Zhang, Z.Y. Identification of a second aryl phosphate-binding site in protein-tyrosine phosphatase $1 \mathrm{~B}$ : a paradigm for inhibitor design. Proc. Natl. Acad. Sci. U.S.A., 1998, 94, 13420-13425.

[56] Jiang, C.S.; Liang, L.F.; Guo, Y.W. Natural products possessing protein tyrosine phosphatase 1B (PTP1B) inhibitory activity found in the last decades. Acta Pharmacol. Sin., 2012, 33, 1217-1245.

[57] Jung, H.J.; Jung, H.A.; Kang, S.S.; Lee, J.H.; Cho, Y.S.; Moon, K.H.; Choi, J.S. Inhibitory activity of Aralia continentalis roots on protein tyrosine phosphatase $1 \mathrm{~B}$ and rat lens aldose reductase. Arch. Pharm. Res., 2012, 35, 1771-1777.

[58] Seo, C.; Sohn, J.H.; Oh, H.; Kim, B.Y.; Ahn, J.S. Isolation of the protein tyrosine phosphatase $1 \mathrm{~B}$ inhibitory metabolite from the marine-derived fungus Cosmospora sp. SF-5060. Bioorg. Med. Chem. Lett., 2009, 19, 6095-6097.

[59] Paululat, T.; Kulik, A.; Hausmann, H.; Karagouni, A.D.; Zinecker, H.; Imhoff, J.F.; Fiedler, H.P. Grecocyclines: New Angucyclines from Streptomyces sp. Eur. J. Org. Chem., 2010, 2344-2350.

[60] Paoli, P.; Cirri, P.; Caselli, A.; Ranaldi, F.; Bruschi, G.; Santi, A.; Camici, G. The insulin-mimetic effect of Morin: a promising molecule in diabetes treatment. Biochim. Biophys. Acta, 2013, 1830, 3102-3111.

[61] Ramírez-Espinosa, J.J.; Rios, M.Y.; López-Martínez, S.; LópezVallejo, F.; Medina-Franco, J.L.; Paoli, P.; Camici, G.; NavarreteVázquez, G.; Ortiz-Andrade, R.; Estrada-Soto, S. Antidiabetic activity of some pentacyclic acid triterpenoids, role of PTP-1B: in vitro, in silico, and in vivo approaches. Eur. J. Med. Chem., 2011, 46, 2243-2251.

[62] Jung, H.A.; Cho, Y.S.; Oh, S.H.; Lee, S.; Min, B.S.; Moon, K.H.; Choi, J.S. Kinetics and molecular docking studies of pimarane-type diterpenes as protein tyrosine phosphatase (PTP1B) inhibitors from Aralia continentalis roots. Arch. Pharm. Res., 2013, 36, 957-965.

[63] Seibert, S.F.; Eguereva, E.; Krick, A.; Kehraus, S.; Voloshina, E.; Raabe, G.; Fleischhauer, J.; Leistner, E.; Wiese, M.; Prinz, H.; Alexandrov, K.; Janning, P.; Waldmann, H.; König, G.M. Polyketides from the marine-derived fungus Ascochyta salicorniae and their potential to inhibit protein phosphatases. Org. Biomol. Chem., 2006, 4, 2233-2240.

[64] Alvi, K.A.; Nair, B.G.; Rabenstein, J.; Davis, G.; Baker, D.D. CD45 tyrosine phosphatase inhibitory components from Aspergillus niger. J. Antibiot., 2000, 53, 110-113.

[65] Bae, E.Y.; Oh, H.; Oh, W.K.; Kim, M.S.; Kim, B.S.; Kim, B.Y.; Sohn, C.B.; Osada, H.; Ahn, J.S. A new VHR dual-specificity protein tyrosine phosphatase inhibitor from Dendrobium moniliforme. Planta Med., 2004, 70, 869-870.

[66] Shi, L.; Zhang, W.; Zhou, Y.Y.; Zhang, Y.N.; Li, J.Y.; Hu, L.H.; $\mathrm{Li}, \mathrm{J}$. Corosolic acid stimulates glucose uptake via enhancing insulin receptor phosphorylation. Eur. J. Pharmacol., 2008, 584, 21-29.

[67] Zhang, W.; Hong, D.; Zhou, Y.; Zhang, Y.; Shen, Q.; Li, J.Y.; Hu, L.H.; Li, J. Ursolic acid and its derivative inhibit protein tyrosine phosphatase $1 \mathrm{~B}$, enhancing insulin receptor phosphorylation and stimulating glucose uptake. Biochim. Biophys. Acta, 2006, 1760, 1505-1512.

[68] Na, M.; Yang, S.; He, L.; Oh, H.; Kim, B.S.; Oh, W.K.; Kim, B.Y.; Ahn, J.S. Inhibition of protein tyrosine phosphatase $1 \mathrm{~B}$ by ursanetype triterpenes isolated from Symplocos paniculata. Planta Med., 2006, 72, 261-263.

[69] Nguyen, P.H.; Yang, J.L.; Uddin, M.N.; Park, S.L.; Lim, S.I.; Jung, D.W.; Williams, D.R.; Oh, W.K. Protein tyrosine phosphatase 1B (PTP1B) inhibitors from Morinda citrifolia (Noni) and their insulin mimetic activity. J. Nat. Prod., 2013, 76, 2080-2087.

[70] Choi, Y.H.; Zhou, W.; Oh, J.; Choe, S.; Kim, D.W.; Lee, S.H.; Na, M. Rhododendric acid A, a new ursane-type PTP1B inhibitor from the endangered plant Rhododendron brachycarpum G. Don. Bioorg. Med. Chem. Lett., 2012, 22, 6116-6119.

[71] Zhang, Y.N.; Zhang, W.; Hong, D.; Shi, L.; Shen, Q.; Li, J.Y.; Li, J.; Hu, L.H. Oleanolic acid and its derivatives: new inhibitor of protein tyrosine phosphatase 1B with cellular activities. Bioorg. Med. Chem., 2008, 16, 8697-8705.

[72] Xu, W.; Zhu, C.; Cheng, W.; Fan, X.; Chen, X.; Yang, S.; Guo, Y.; Ye, F.; Shi, J. Chemical Constituents of the Roots of Euphorbia micractina. J. Nat. Prod., 2009, 72, 1620-1626.
[73] Li, Y.F.; Hu, L.H.; Lou, F.C.; Li, J.; Shen, Q. PTP1B inhibitors from Ardisia japonica. J Asian Nat Prod Res, 2004, 7, 13-18.

[74] Liang, L.F.; Kurtán, T.; Mándi, A.; Yao, L.G.; Li, J.; Zhang, W.; Guo, Y.W. Unprecedented diterpenoids as a PTP1B inhibitor from the Hainan soft coral Sarcophyton trocheliophorum Marenzeller. Org. Lett., 2013, 15, 274-277.

[75] Baumgartner, R.R.; Steinmann, D.; Heiss, E.H.; Atanasov, A.G.; Ganzera, M.; Stuppner, H.; Dirsch, V.M. Bioactivity-guided isolation of 1,2,3,4,6-Penta-O-galloyl-D-glucopyranose from Paeonia lactiflora roots as a PTP1B inhibitor. J. Nat. Prod., 2010, 73, 15781581.

[76] Heiss, E.H.; Baumgartner, L.; Schwaiger, S.; Heredia, R.J.; Atanasov, A.G.; Rollinger, J.M.; Stuppner, H.; Dirsch, V.M. Ratanhiaphenol III from Ratanhiae radix is a PTP1B inhibitor. Planta Med., 2012, 78, 678-681.

[77] Na, M.; Kim, K.A.; Oh, H.; Kim, B.Y.; Oh, W.K.; Ahn, J.S. Protein tyrosine phosphatase $1 \mathrm{~B}$ inhibitory activity of amentoflavone and its cellular effect on tyrosine phosphorylation of insulin receptors. Biol. Pharm. Bull., 2007, 30, 379-381.

[78] Lee, M.S.; Kim, C.H.; Hoang, D.M.; Kim, B.Y.; Sohn, C.B.; Kim, M.R.; Ahn, J.S. Genistein-derivatives from Tetracera scandens stimulate glucose-uptake in L6 myotubes. Biol. Pharm. Bull., 2009, 32, 504-508.

[79] Li, J.M.; Li, Y.C.; Kong, L.D.; Hu, Q.H. Curcumin inhibits hepatic protein-tyrosine phosphatase $1 \mathrm{~B}$ and prevents hypertriglyceridemia and hepatic steatosis in fructose-fed rats. Hepatology, 2010, 51, 1555-1566.

[80] Kelley, G.L.; Allan, G.; Azhar, S. High dietary fructose induces a hepatic stress response resulting in cholesterol and lipid dysregulation. Endocrinology, 2003, 145, 548-555.

[81] Bustanji, Y.; Taha, M.O.; Al-Masri, I.M.; Mohammad, M.K. Docking simulations and in vitro assay unveil potent inhibitory action of papaverine against protein tyrosine phosphatase 1B. Biol. Pharm. Bull., 2009, 32, 640-645.

[82] Bustanji, Y.; Taha, M.O.; Yousef, A.M.; Al-Bakri, A.G. Berberine potently inhibits protein tyrosine phosphatase 1B: investigation by docking simulation and experimental validation. J. Enzyme Inhib. Med. Chem., 2006, 21, 163-171.

[83] Chen, C.; Zhang, Y.; Huang, C. Berberine inhibits PTP1B activity and mimics insulin action. Biochem. Biophys. Res. Commun., 2010, 397, 543-547.

[84] Zhang, Y.; Li, X.; Zou, D.; Liu, W.; Yang, J.; Zhu, N.; Huo, L.; Wang, M.; Hong, J.; Wu, P.; Ren, G.; Ning, G. Treatment of type 2 diabetes and dyslipidemia with the natural plant alkaloid berberine. J. Clin. Endocrinol. Metab., 2008, 93, 2559-2565.

[85] Tamrakar, A.K.; Yadav, P.P.; Tiwari, P.; Maurya, R.; Srivastava, A.K. Identification of pongamol and karanjin as lead compounds with antihyperglycemic activity from Pongamia pinnata fruits. $J$. Ethnopharmacol., 2008, 118, 435-439.

[86] Sun, T.; Wang, Q.; Yu, Z.; Zhang, Y.; Guo, Y.; Chen, K.; Shen, X.; Jiang, H. Hyrtiosal, a PTP1B inhibitor from the marine sponge Hyrtios erectus, shows extensive cellular effects on PI3K/AKT activation, glucose transport, and TGFbeta/Smad2 signaling. Chembiochem, 2006, 8, 187-193.

[87] Lantz, K.A.; Hart, S.G.; Planey, S.L.; Roitman, M.F.; Ruiz-White, I.A.; Wolfe, H.R.; McLane, M.P. Inhibition of PTP1B by trodusquemine (MSI-1436) causes fat-specific weight loss in dietinduced obese mice. Obesity (Silver Spring), 2010, 18, 1516-1523.

[88] Takahashi, N.; Qi, Y.; Patel, H.R.; Ahima, R.S. A novel aminosterol reverses diabetes and fatty liver disease in obese mice. J. Hepatol., 2004, 41, 391-398.

[89] Hardie, D.G. Sensing of energy and nutrients by AMP-activated protein kinase. Am. J. Clin. Nutr., 2011, 93, 891S-6.

[90] Kane, S.; Sano, H.; Liu, S.C.; Asara, J.M.; Lane, W.S.; Garner, C.C.; Lienhard, G.E. A method to identify serine kinase substrates. Akt phosphorylates a novel adipocyte protein with a Rab GTPaseactivating protein (GAP) domain. J. Biol. Chem., 2002, 277, 22115-22118.

[91] Towler, M.C.; Hardie, D.G. AMP-activated protein kinase in metabolic control and insulin signaling. Circ. Res., 2007, 100, 328-341.

[92] Dzamko, N.L.; Steinberg, G.R. AMPK-dependent hormonal regulation of whole-body energy metabolism. Acta Physiol. (Oxf.), 2009, 196, 115-127.

[93] Woods, A.; Azzout-Marniche, D.; Foretz, M.; Stein, S.C.; Lemarchand, P.; Ferré, P.; Foufelle, F.; Carling, D. Characterization of 
the role of AMP-activated protein kinase in the regulation of glucose-activated gene expression using constitutively active and dominant negative forms of the kinase. Mol. Cell. Biol., 2000, 20, 6704-6711.

[94] Kahn, B.B.; Alquier, T.; Carling, D.; Hardie, D.G. AMP-activated protein kinase: ancient energy gauge provides clues to modern understanding of metabolism. Cell. Metab., 2005, 1, 15-25.

[95] Terada, S.; Goto, M.; Kato, M.; Kawanaka, K.; Shimokawa, T.; Tabata, I. Effects of low-intensity prolonged exercise on PGC-1 mRNA expression in rat epitrochlearis muscle. Biochem. Biophys. Res. Commun., 2002, 296, 350-354.

[96] Zong, H.; Ren, J.M.; Young, L.H.; Pypaert, M.; Mu, J.; Birnbaum, M.J.; Shulman, G.I. AMP kinase is required for mitochondrial biogenesis in skeletal muscle in response to chronic energy deprivation. Proc. Natl. Acad. Sci. U.S.A., 2002, 99, 15983-15987.

[97] Holmes, B.F.; Kurth-Kraczek, E.J.; Winder, W.W. Chronic activation of 5'-AMP-activated protein kinase increases GLUT-4, hexokinase, and glycogen in muscle. J. Appl. Physiol., 1999, 87, 1990-1995.

[98] Zheng, D.; MacLean, P.S.; Pohnert, S.C.; Knight, J.B.; Olson, A.L.; Winder, W.W.; Dohm, G.L. Regulation of muscle GLUT-4 transcription by AMP-activated protein kinase. J. Appl. Physiol., 2001, 91, 1073-1083.

[99] McGee, S.L.; van Denderen, B.J.; Howlett, K.F.; Mollica, J.; Schertzer, J.D.; Kemp, B.E.; Hargreaves, M. AMP-activated protein kinase regulates GLUT4 transcription by phosphorylating histone deacetylase 5. Diabetes, 2008, 57, 860-867.

[100] Lochhead, P.A.; Salt, I.P.; Walker, K.S.; Hardie, D.G.; Sutherland, C. 5-aminoimidazole-4-carboxamide riboside mimics the effects of insulin on the expression of the 2 key gluconeogenic genes PEPCK and glucose-6-phosphatase. Diabetes, 2000, 49, 896-903.

[101] Cool, B.; Zinker, B.; Chiou, W.; Kifle, L.; Cao, N.; Perham, M.; Dickinson, R.; Adler, A.; Gagne, G.; Iyengar, R.; Zhao, G.; Marsh, K.; Kym, P.; Jung, P.; Camp, H.S.; Frevert, E. Identification and characterization of a small molecule AMPK activator that treats key components of type 2 diabetes and the metabolic syndrome. Cell Metab., 2006, 3, 403-416.

[102] Sell, H.; Dietze-Schroeder, D.; Eckel, J. The adipocyte-myocyte axis in insulin resistance. Trends Endocrinol. Metab., 2006, 17, 416-422.

[103] Desvergne, B.; Wahli, W. Peroxisome proliferator-activated receptors: nuclear control of metabolism. Endocr. Rev., 1999, 20, 649688.

[104] Gelman, L.; Feige, J.N.; Desvergne, B. Molecular basis of selective PPARgamma modulation for the treatment of Type 2 diabetes. Biochim. Biophys. Acta, 2007, 1771, 1094-1107.

[105] Montagner, A.; Rando, G.; Degueurce, G.; Leuenberger, N.; Michalik, L.; Wahli, W. New insights into the role of PPARs. Prostaglandins Leukot. Essent. Fatty Acids, 2011, 85, 235-243.

[106] Koves, T.R.; Ussher, J.R.; Noland, R.C.; Slentz, D.; Mosedale, M.; Ilkayeva, O.; Bain, J.; Stevens, R.; Dyck, J.R.; Newgard, C.B.; Lopaschuk, G.D.; Muoio, D.M. Mitochondrial overload and incomplete fatty acid oxidation contribute to skeletal muscle insulin resistance. Cell Metab., 2008, 7, 45-56.

[107] Befroy, D.E.; Petersen, K.F.; Dufour, S.; Mason, G.F.; de Graaf, R.A.; Rothman, D.L.; Shulman, G.I. Impaired mitochondrial substrate oxidation in muscle of insulin-resistant offspring of type 2 diabetic patients. Diabetes, 2007, 56, 1376-1381.

[108] Kelley, D.E.; He, J.; Menshikova, E.V.; Ritov, V.B. Dysfunction of mitochondria in human skeletal muscle in type 2 diabetes. Diabetes, 2002, 51, 2944-2950.

[109] Mogensen, M.; Sahlin, K.; Fernström, M.; Glintborg, D.; Vind, B.F.; Beck-Nielsen, H.; Højlund, K. Mitochondrial respiration is decreased in skeletal muscle of patients with type 2 diabetes. Diabetes, 2007, 56, 1592-1599.

[110] Chavez, J.A.; Summers, S.A. A ceramide-centric view of insulin resistance. Cell Metab., 2012, 15, 585-594.

[111] Yang, R.; Trevillyan, J.M. c-Jun N-terminal kinase pathways in diabetes. Int. J. Biochem. Cell Biol., 2008, 40, 2702-2706.

[112] Panzhinskiy, E.; Hua, Y.; Culver, B.; Ren, J.; Nair, S. Endoplasmic reticulum stress upregulates protein tyrosine phosphatase 1B and impairs glucose uptake in cultured myotubes. Diabetologia, 2012, $56,598-607$
[113] Fiévet, C.; Fruchart, J.C.; Staels, B. PPARalpha and PPARgamma dual agonists for the treatment of type 2 diabetes and the metabolic syndrome. Curr. Opin. Pharmacol., 2006, 6, 606-614.

[114] Kramer, D.; Shapiro, R.; Adler, A.; Bush, E.; Rondinone, C.M. Insulin-sensitizing effect of rosiglitazone (BRL-49653) by regulation of glucose transporters in muscle and fat of Zucker rats. $\mathrm{Me}$ tab. Clin. Exp., 2001, 50, 1294-1300.

[115] Baumann, C.A.; Chokshi, N.; Saltiel, A.R.; Ribon, V. Cloning and characterization of a functional peroxisome proliferator activator receptor-gamma-responsive element in the promoter of the CAP gene. J. Biol. Chem., 2000, 275, 9131-9135.

[116] Yamauchi, T.; Kamon, J.; Waki, H.; Terauchi, Y.; Kubota, N.; Hara, K.; Mori, Y.; Ide, T.; Murakami, K.; Tsuboyama-Kasaoka, N.; Ezaki, O.; Akanuma, Y.; Gavrilova, O.; Vinson, C.; Reitman, M.L.; Kagechika, H.; Shudo, K.; Yoda, M.; Nakano, Y.; Tobe, K.; Nagai, R.; Kimura, S.; Tomita, M.; Froguel, P.; Kadowaki, T. The fat-derived hormone adiponectin reverses insulin resistance associated with both lipoatrophy and obesity. Nat. Med., 2001, 7, 941946.

[117] Wang, Y.X.; Lee, C.H.; Tiep, S.; Yu, R.T.; Ham, J.; Kang, H.; Evans, R.M. Peroxisome-proliferator-activated receptor delta activates fat metabolism to prevent obesity. Cell, 2003, 113, 159-170.

[118] Luquet, S.; Lopez-Soriano, J.; Holst, D.; Fredenrich, A.; Melki, J.; Rassoulzadegan, M.; Grimaldi, P.A. Peroxisome proliferatoractivated receptor delta controls muscle development and oxidative capability. FASEB J., 2003, 17, 2299-2301.

[119] Krämer, D.K.; Al-Khalili, L.; Perrini, S.; Skogsberg, J.; Wretenberg, P.; Kannisto, K.; Wallberg-Henriksson, H.; Ehrenborg, E. Zierath, J.R.; Krook, A. Direct activation of glucose transport in primary human myotubes after activation of peroxisome proliferator-activated receptor delta. Diabetes, 2005, 54, 1157-1163.

[120] Lee, C.H.; Olson, P.; Hevener, A.; Mehl, I.; Chong, L.W.; Olefsky, J.M.; Gonzalez, F.J.; Ham, J.; Kang, H.; Peters, J.M.; Evans, R.M. PPARdelta regulates glucose metabolism and insulin sensitivity. Proc. Natl. Acad. Sci. U.S.A., 2006, 103, 3444-3449.

[121] Chen, R.M.; Hu, L.H.; An, T.Y.; Li, J.; Shen, Q. Natural PTP1B inhibitors from Broussonetia papyrifera. Bioorg. Med. Chem. Lett., 2002, 12, 3387-3390.

[122] Zhang, J.; Shen, Q.; Cai Lu, J.C; Li, J.Y.; Liu, W.Y; Jyang, J.J.; Li, j.; Xiao, K. Phenolic compounds from the leaves of Cyclocarya paliurus (Batal.) Ijinskaja and their inhibitory activity against PTP1B. Food Chem., 2010, 119, 1491-1496.

[123] Cui, L.; Ndinteh, D.T.; Na, M.; Thuong, P.T.; Silike-Muruumu, J.; Njamen, D.; Mbafor, J.T.; Fomum, Z.T.; Ahn, J.S.; Oh, W.K. Isoprenylated flavonoids from the stem bark of Erythrina abyssinica. J. Nat. Prod., 2007, 70, 1039-1042.

[124] Cui, L.; Thuong, P.T.; Lee, H.S.; Ndinteh, D.T.; Mbafor, J.T.; Fomum, Z.T.; Oh, W.K. Flavanones from the stem bark of Erythrina abyssinica. Bioorg. Med. Chem., 2008, 16, 10356-10362.

[125] Cui, L.; Lee, H.S.; Ndinteh, D.T.; Mbafor, J.T.; Kim, Y.H.; Le, T.V.; Nguyen, P.H.; Oh, W.K. New prenylated flavanones from Erythrina abyssinica with protein tyrosine phosphatase 1B (PTP1B) inhibitory activity. Planta Med., 2009, 76, 713-718.

[126] Nguyen, P.H.; Dao, T.T.; Kim, J.; Phong, d.o.T.; Ndinteh, D.T.; Mbafor, J.T.; Oh, W.K. New 5-deoxyflavonoids and their inhibitory effects on protein tyrosine phosphatase 1B (PTP1B) activity. Bioorg. Med. Chem., 2011, 19, 3378-3383.

[127] Nguyen, P.H.; Le, T.V.; Thuong, P.T.; Dao, T.T.; Ndinteh, D.T.; Mbafor, J.T.; Kang, K.W.; Oh, W.K. Cytotoxic and PTP1B inhibitory activities from Erythrina abyssinica. Bioorg. Med. Chem. Lett., 2009, 19, 6745-6749.

[128] Bae, E.Y.; Na, M.; Njamen, D.; Mbafor, J.T.; Fomum, Z.T.; Cui, L.; Choung, D.H.; Kim, B.Y.; Oh, W.K.; Ahn, J.S. Inhibition of protein tyrosine phosphatase $1 \mathrm{~B}$ by prenylated isoflavonoids isolated from the stem bark of Erythrina addisoniae. Planta Med., 2006, 72, 945-948.

[129] Dao, T.T.; Nguyen, P.H.; Thuong, P.T.; Kang, K.W.; Na, M.; Ndinteh, D.T.; Mbafor, J.T.; Oh, W.K. Pterocarpans with inhibitory effects on protein tyrosine phosphatase 1B from Erythrina lysistemon Hutch. Phytochemistry, 2009, 70, 2053-2057.

[130] Na, M.; Jang, J.; Njamen, D.; Mbafor, J.T.; Fomum, Z.T.; Kim, B.Y.; Oh, W.K.; Ahn, J.S. Protein tyrosine phosphatase-1B inhibitory activity of isoprenylated flavonoids isolated from Erythrina mildbraedii. J. Nat. Prod., 2006, 69, 1572-1576. 
[131] Jang, J.; Na, M.; Thuong, P.T.; Njamen, D.; Mbafor, J.T.; Fomum, Z.T.; Woo, E.R.; Oh, W.K. Prenylated flavonoids with PTP1B inhibitory activity from the root bark of Erythrina mildbraedii. Chem. Pharm. Bull., 2008, 56, 85-88.

[132] Li, W.; Li, S.; Higai, K.; Sasaki, T.; Asada, Y.; Ohshima, S.; Koike, K. Evaluation of licorice flavonoids as protein tyrosine phosphatase 1B inhibitors. Bioorg. Med. Chem. Lett., 2013, 23, 58365839.

[133] Li, S.; Li, W.; Wang, Y.; Asada, Y.; Koike, K. Prenylflavonoids from Glycyrrhiza uralensis and their protein tyrosine phosphatase1B inhibitory activities. Bioorg. Med. Chem. Lett., 2010, 20, 53985401.

[134] Hoang, D.M.; Ngoc, T.M.; Dat, N.T.; Ha, d.o.T.; Kim, Y.H.; Luong, H.V.; Ahn, J.S.; Bae, K. Protein tyrosine phosphatase 1B inhibitors isolated from Morus bombycis. Bioorg. Med. Chem. Lett., 2009, 19, 6759-6761.

[135] Cui, L.; Na, M.; Oh, H.; Bae, E.Y.; Jeong, D.G.; Ryu, S.E.; Kim, S.; Kim, B.Y.; Oh, W.K.; Ahn, J.S. Protein tyrosine phosphatase 1B inhibitors from Morus root bark. Bioorg. Med. Chem. Lett., 2005, 16, 1426-1429.

[136] Lee, D.S.; Jang, J.H.; Ko, W.; Kim, K.S.; Sohn, J.H.; Kang, M.S.; Ahn, J.S.; Kim, Y.C.; Oh, H. PTP1B inhibitory and antiinflammatory effects of secondary metabolites isolated from the marine-derived fungus Penicillium sp. JF-55. Mar. Drugs, 2013, $11,1409-1426$.

[137] Wang, Y.; Shang, X.Y.; Wang, S.J.; Mo, S.Y.; Li, S.; Yang, Y.C.; Ye, F.; Shi, J.G.; He, L. Structures, biogenesis, and biological activities of pyrano[4,3-c]isochromen-4-one derivatives from the Fungus Phellinus igniarius. J. Nat. Prod., 2007, 70, 296-299.

[138] Kim, Y.C.; Oh, H.; Kim, B.S.; Kang, T.H.; Ko, E.K.; Han, Y.M.; Kim, B.Y.; Ahn, J.S. In vitro protein tyrosine phosphatase 1B inhibitory phenols from the seeds of Psoralea corylifolia. Planta Med., 2005, 71, 87-89.

[139] Na, M.; Hoang, D.M.; Njamen, D.; Mbafor, J.T.; Fomum, Z.T.; Thuong, P.T.; Ahn, J.S.; Oh, W.K. Inhibitory effect of 2arylbenzofurans from Erythrina addisoniae on protein tyrosine phosphatase-1B. Bioorg. Med. Chem. Lett., 2007, 17, 3868-3871.

[140] Seo, C.; Sohn, J.H.; Park, S.M.; Yim, J.H.; Lee, H.K.; Oh, H. Usimines A-C, bioactive usnic acid derivatives from the Antarctic lichen Stereocaulon alpinum. J. Nat. Prod., 2008, 71, 710-712.

[141] Na, M.; Oh, W.K.; Kim, Y.H.; Cai, X.F.; Kim, S.; Kim, B.Y.; Ahn, J.S. Inhibition of protein tyrosine phosphatase 1B by diterpenoids isolated from Acanthopanax koreanum. Bioorg. Med. Chem. Lett., 2006, 16, 3061-3064.

[142] Na, M.; Cui, L.; Min, B.S.; Bae, K.; Yoo, J.K.; Kim, B.Y.; Oh, W.K.; Ahn, J.S. Protein tyrosine phosphatase 1B inhibitory activity of triterpenes isolated from Astilbe koreana. Bioorg. Med. Chem. Lett., 2006, 16, 3273-3276.

[143] Shao, Z.Y.; Li, J.; Sim, C.J.; Li, J.Y.; Li, Z.Y.; Nan, F.J.; Guo, Y.W. O-methyl nakafuran-8 lactone, a new sesquiterpenoid from a hainan marine sponge Dysidea sp. J. Asian Nat. Prod. Res., 2006, 8, 223-227.

[144] Huang, X.C.; Li, J.; Li, Z.Y.; Shi, L.; Guo, Y.W. Sesquiterpenes from the Hainan Sponge Dysidea septosa. J. Nat. Prod., 2008, 71, 1399-1403.

[145] Li, Y.; Zhang, Y.; Shen, X.; Guo, Y.W. A novel sesquiterpene quinone from Hainan sponge Dysidea villosa. Bioorg. Med. Chem. Lett., 2008, 19, 390-392.

[146] Hung, T.M.; Hoang, D.M.; Kim, J.C.; Jang, H.S.; Ahn, J.S.; Min, B.S. Protein tyrosine phosphatase 1B inhibitory by dammaranes from Vietnamese Giao-Co-Lam tea. J. Ethnopharmacol., 2009, 124, 240-245.

[147] Cui, Y.; Yim, J.H.; Lee, D.S.; Kim, Y.C.; Oh, H. New diterpene furanoids from the Antarctic lichen Huea sp. Bioorg. Med. Chem. Lett., 2012, 22, 7393-7396.

[148] Cebula, R.E.; Blanchard, J.L.; Boisclair, M.D.; Pal, K.; Bockovich, N.J. Synthesis and phosphatase inhibitory activity of analogs of sulfircin. Bioorg. Med. Chem. Lett., 1997, 7, 2015-2020.

[149] Deng, M.; Dong, W.; Jiao, W.; Lu, R. New Eremophilane Sesquiterpenes from the Roots of Ligularia fischeri. Helv. Chim. Acta, 2009, 92, 495-501.

[150] Kate, A.S.; Aubry, I.; Tremblay, M.L.; Kerr, R.G. Lipidyl pseudopteranes A-F: isolation, biomimetic synthesis, and PTP1B inhibitory activity of a new class of pseudopteranoids from the Gorgonian Pseudopterogorgia acerosa. J. Nat. Prod., 2008, 71, 1977-1982.
[151] Fu, H.Z.; Luo, Y.M.; Li, C.J.; Yang, J.Z.; Zhang, D.M. Psidials A$\mathrm{C}$, three unusual meroterpenoids from the leaves of Psidium guajava L. Org. Lett., 2010, 12, 656-659.

[152] Han, Y.M.; Oh, H.; Na, M.; Kim, B.S.; Oh, W.K.; Kim, B.Y.; Jeong, D.G.; Ryu, S.E.; Sok, D.E.; Ahn, J.S. PTP1B inhibitory effect of abietane diterpenes isolated from Salvia miltiorrhiza. Biol. Pharm. Bull., 2005, 28, 1795-1797.

[153] Liang, L.F.; Gao, L.X.; Li, J.; Taglialatela-Scafati, O.; Guo, Y.W. Cembrane diterpenoids from the soft coral Sarcophyton trocheliophorum Marenzeller as a new class of PTP1B inhibitors. Bioorg. Med. Chem., 2013, 21, 5076-5080.

[154] Choi, J.Y.; Na, M.; Hyun Hwang, I.; Ho Lee, S.; Young Bae, E.; Yeon Kim, B.; Seog Ahn, J. Isolation of betulinic acid, its methyl ester and guaiane sesquiterpenoids with protein tyrosine phosphatase 1B inhibitory activity from the roots of Saussurea lappa C.B.Clarke. Molecules, 2009, 14, 266-272.

[155] Kim, S.; Na, M.; Oh, H.; Jang, J.; Sohn, C.B.; Kim, B.Y.; Oh, W.K.; Ahn, J.S. PTP1B inhibitory activity of kaurane diterpenes isolated from Siegesbeckia glabrescens. J. Enzyme Inhib. Med. Chem., 2006, 21, 379-383.

[156] Na, M.; Kim, B.Y.; Osada, H.; Ahn, J.S. Inhibition of protein tyrosine phosphatase $1 \mathrm{~B}$ by lupeol and lupenone isolated from Sorbus commixta. J. Enzyme Inhib. Med. Chem., 2009, 24, 1056-1059.

[157] Kwon, J.H.; Chang, M.J.; Seo, H.W.; Lee, J.H.; Min, B.S.; Na, M.; Kim, J.C.; Woo, M.H.; Choi, J.S.; Lee, H.K.; Bae, K. Triterpenoids and a sterol from the stem-bark of Styrax japonica and their protein tyrosine phosphatase 1B inhibitory activities. Phytother. Res., 2008, 22, 1303-1306.

[158] Na, M.; Thuong, P.T.; Hwang, I.H.; Bae, K.; Kim, B.Y.; Osada, H.; Ahn, J.S. Protein tyrosine phosphatase 1B inhibitory activity of 24norursane triterpenes isolated from Weigela subsessilis. Phytother. Res., 2010, 24, 1716-1719.

[159] He, Z.Z.; Yan, J.F.; Song, Z.J.; Ye, F.; Liao, X.; Peng, S.L.; Ding, L.S. Chemical constituents from the aerial parts of Artemisia minor. J. Nat. Prod., 2009, 72, 1198-1201.

[160] Feng, Y.; Carroll, A.R.; Addepalli, R.; Fechner, G.A.; Avery, V.M.; Quinn, R.J. Vanillic acid derivatives from the green algae Cladophora socialis as potent protein tyrosine phosphatase $1 \mathrm{~B}$ inhibitors. J. Nat. Prod., 2007, 70, 1790-1792.

[161] Lee, Y.S.; Kang, I.J.; Won, M.H.; Lee, J.Y.; Kim, J.K.; Lim, S.S. Inhibition of protein tyrosine phosphatase 1 beta by hispidin derivatives isolated from the fruiting body of Phellinus linteus. Nat. Prod. Commun., 2011, 5, 1927-1930.

[162] Shi, D.; Xu, F.; Juan, He, J.; Li, J.; Fan, X.; Han, L.J. Inhibition of bromophenols against PTP1B and anti-hyperglycaemic effect of Rhodomela confervoides extract in diabetic rats" Chin. Sci. Bull., 2008, 53, 2476-2479.

[163] Shi, D.Y.; Xu, F.; Li, J.; Guo, S.J.; Su, H.; Han, L.J. [PTP1B inhibitory activities of bromophenol derivatives from algae]. Zhongguo Zhong Yao Za Zhi, 2009, 33, 2238-2240.

[164] Xu, L.; Li, Xiaoming ; Lixin, G.; Chuanming, C.; Chunshun, L.; Jia, L.; Bingui, W. Extraction and PTP1B inhibitory activity of bromophenols from the marine red alga Symphyocladia latiuscula. Chin. J. Oceanol. Limno, 2011, 29, 686-690.

[165] Seo, C.; Choi, Y.H.; Ahn, J.S.; Yim, J.H.; Lee, H.K.; Oh, H. PTP1B inhibitory effects of tridepside and related metabolites isolated from the Antarctic lichen Umbilicaria antarctica. J. Enzyme Inhib. Med. Chem., 2009, 24, 1133-1137.

[166] Li, Y.F.; Li, J.; Shen, Q.; Hu, L.H. Benzoquinones from Ardisia japonica with inhibitory activity towards human protein tyrosine phosphatase 1B (PTP1B). Chem. Biodivers., 2007, 4, 961-965.

[167] Otani, T.; Sugimoto, Y.; Aoyagi, Y.; Igarashi, Y.; Furumai, T.; Saito, N.; Yamada, Y.; Asao, T.; Oki, T. New Cdc25B tyrosine phosphatase inhibitors, nocardiones $\mathrm{A}$ and $\mathrm{B}$, produced by Nocardia sp. TP-A0248: taxonomy, fermentation, isolation, structural elucidation and biological properties. J. Antibiot., 2000, 53, 337344.

[168] Seo, C.; Choi, Y.H.; Sohn, J.H.; Ahn, J.S.; Yim, J.H.; Lee, H.K.; $\mathrm{Oh}, \mathrm{H}$. Ohioensins $\mathrm{F}$ and $\mathrm{G}$ : protein tyrosine phosphatase $1 \mathrm{~B}$ inhibitory benzonaphthoxanthenones from the Antarctic moss Polytrichastrum alpinum. Bioorg. Med. Chem. Lett., 2007, 18, 772-775.

[169] Mao, S.C.; Guo, Y.W.; Shen, X. Two novel aromatic valerenanetype sesquiterpenes from the Chinese green alga Caulerpa taxifolia. Bioorg. Med. Chem. Lett., 2006, 16, 2947-2950. 
[170] Sohn, J.H.; Lee, Y.R.; Lee, D.S.; Kim, Y.C.; Oh, H. PTP1B inhibitory secondary metabolites from marine-derived fungal strains Penicillium spp. and Eurotium sp. J. Microbiol. Biotechnol., 2013, 23, 1206-1211.

[171] Lee, H.S.; Hwang, I.H.; Kim, J.A.; Choi, J.Y.; Jang, T.S.; Osada, H.; Ahn ,J.S.; Na, M.K., Lee, S.H. Isolation of Protein Tyrosine Phosphatase 1B Inhibitory Constituents from the Sclerotia of Polyporus umbellatus. Fries Bull. Korean Chem. Soc., 2011, 32, 697700 .

[172] Oh, H.; Kim, B.S.; Bae, E.Y.; Kim, M.S.; Kim, B.Y.; Lee, H.B.; Kim, C.J.; Ahn, J.S. Inhibition of PTP1B by metabolites from Micromucor ramannianus var. angulisporus CRM000232. J. Antibiot., 2004, 57, 528-531.

[173] Schulz, D.; Nachtigall, J.; Riedlinger, J.; Schneider, K.; Poralla, K.; Imhoff, J.F.; Beil, W.; Nicholson, G.; Fiedler, H.P.; Süssmuth, R.D. Piceamycin and its $\mathrm{N}$-acetylcysteine adduct is produced by Streptomyces sp. GB 4-2. J. Antibiot., 2009, 62, 513-518.

[174] Gong, J.X.; Shen, X.; Yao, L.G.; Jiang, H.; Krohn, K.; Guo, Y.W. Total synthesis of gymnorrhizol, an unprecedented 15-membered macrocyclic polydisulfide from the Chinese mangrove Bruguiera gymnorrhiza. Org. Lett., 2007, 9, 1715-1716.

[175] Huang, X.Y.; Wang, Q.; Liu, H.L.; Zhang, Y.; Xin, G.R.; Shen, X.; Dong, M.L.; Guo, Y.W. Diastereoisomeric macrocyclic polydisulfides from the mangrove Bruguiera gymnorrhiza. Phytochemistry, 2009, 70, 2096-2100.

[176] Wang, J.D.; Dong, M.L.; Zhang, W.; Shen, X.; Guo, Y.W. Chemical constituents of mangrove plant Aegiceras corniculatum. Chin. J. Nat. Med., 2006, 4, 275-277.

[177] Qin, J.; Su, H.; Zhang, Y.; Gao, J.; Zhu, L.; Wu, X.; Pan, H.; Li, X. Highly brominated metabolites from marine red alga Laurencia similis inhibit protein tyrosine phosphatase 1B. Bioorg. Med. Chem. Lett., 2010, 20, 7152-7154.

[178] Yu, H.B.; Liu, X.F.; Xu, Y.; Gan, J.H.; Jiao, W.H.; Shen, Y.; Lin, H.W. Woodylides A-C, new cytotoxic linear polyketides from the South China Sea sponge Plakortis simplex. Mar. Drugs, 2012, 10, 1027-1036.

[179] Piao, S.J.; Zhang, H.J.; Lu, H.Y.; Yang, F.; Jiao, W.H.; Yi, Y.H.; Chen, W.S.; Lin, H.W. Hippolides A-H, acyclic manoalide derivatives from the marine sponge Hippospongia lachne. J. Nat. Prod., 2011, 74, 1248-1254.

[180] Akuda, Y.; Kubota, T.; Shima, H.; Okada, T.; Mitsuhashi, S.; Aoki, N.; Kikuchi, K.; Kobayashi, J. Manzamenones Inhibit T-Cell Protein Tyrosine Phosphatase. Mar. Drugs, 2006, 4, 9-14.

[181] Hohmann, C.; Schneider, K.; Bruntner, C.; Brown, R.; Jones, A.L.; Goodfellow, M.; Krämer, M.; Imhoff, J.F.; Nicholson, G.; Fiedler, H.P.; Süssmuth, R.D. Albidopyrone, a new alpha-pyronecontaining metabolite from marine-derived Streptomyces sp. NTK 227. J. Antibiot., 2009, 62, 75-79.

[182] Seo, C.; Sohn, J.H.; Ahn, J.S.; Yim, J.H.; Lee, H.K.; Oh, H. Protein tyrosine phosphatase $1 \mathrm{~B}$ inhibitory effects of depsidone and pseudodepsidone metabolites from the Antarctic lichen Stereocaulon alpinum. Bioorg. Med. Chem. Lett., 2009, 19, 2801-2803.

[183] Yang, S.; Na, M.K.; Jang, J.P.; Kim, K.A.; Kim, B.Y.; Sung, N.J.; Oh, W.K.; Ahn, J.S. Inhibition of protein tyrosine phosphatase 1B by lignans from Myristica fragrans. Phytother. Res., 2006, 20, 680682.

[184] Wang, J.R.; Shen, Q.; Fang, L.; Peng, S.Y.; Yang, Y.M.; Li, J.; Liu, H.L.; Guo, Y.W. Structural and stereochemical studies of five new pregnane steroids from the stem bark of Toona ciliata var. pubescens. Steroids, 2011, 76, 571-576.

[185] Rao, M.N.; Shinnar, A.E.; Noecker, L.A.; Chao, T.L.; Feibush, B.; Snyder, B.; Sharkansky, I.; Sarkahian, A.; Zhang, X.; Jones, S.R.; Kinney, W.A.; Zasloff, M. Aminosterols from the dogfish shark Squalus acanthias. J. Nat. Prod., 2000, 63, 631-635.

[186] Eid, H.M.; Martineau, L.C.; Saleem, A.; Muhammad, A.; Vallerand, D.; Benhaddou-Andaloussi, A.; Nistor, L.; Afshar, A.; Arnason, J.T.; Haddad, P.S. Stimulation of AMP-activated protein kinase and enhancement of basal glucose uptake in muscle cells by quercetin and quercetin glycosides, active principles of the antidiabetic medicinal plant Vaccinium vitis-idaea. Mol. Nutr. Food Res., 2010, 54, 991-1003.

[187] Yoon, E.K.; Jeong, Y.T.; Li, X.; Song-Cui.; Park, D.C.; Kim, Y.H.; Kim, Y.D.; Chang, H.W.; Lee, S.H.; Hwang, S.L. Glyceollin improves endoplasmic reticulum stress-induced insulin resistance through CaMKK-AMPK pathway in L6 myotubes. J. Nutr. Biochem., 2013, 24, 1053-1061.

[188] Liu, J.F.; Ma, Y.; Wang, Y.; Du, Z.Y.; Shen, J.K.; Peng, H.L. Reduction of lipid accumulation in HepG2 cells by luteolin is associated with activation of AMPK and mitigation of oxidative stress. Phytother. Res., 2010, 25, 588-596.

[189] Hwang, Y.P.; Kim, H.G.; Choi, J.H.; Do, M.T.; Chung, Y.C.; Jeong, T.C.; Jeong, H.G. S-allyl cysteine attenuates free fatty acidinduced lipogenesis in human HepG2 cells through activation of the AMP-activated protein kinase-dependent pathway. J. Nutr. Biochem., 2013, 24, 1469-1478.

[190] Lee, Y.S.; Cha, B.Y.; Saito, K.; Yamakawa, H.; Choi, S.S.; Yamaguchi, K.; Yonezawa, T.; Teruya, T.; Nagai, K.; Woo, J.T. Nobiletin improves hyperglycemia and insulin resistance in obese diabetic ob/ob mice. Biochem. Pharmacol., 2010, 79, 1674-1683.

[191] Mulvihill, E.E.; Assini, J.M.; Lee, J.K.; Allister, E.M.; Sutherland, B.G.; Koppes, J.B.; Sawyez, C.G.; Edwards, J.Y.; Telford, D.E.; Charbonneau, A.; St-Pierre, P.; Marette, A.; Huff, M.W. Nobiletin attenuates VLDL overproduction, dyslipidemia, and atherosclerosis in mice with diet-induced insulin resistance. Diabetes, 2011, 60, 1446-1457.

[192] He, Y.; Li, Y.; Zhao, T.; Wang, Y.; Sun, C. Ursolic acid inhibits adipogenesis in 3T3-L1 adipocytes through LKB1/AMPK pathway. PLoS ONE, 2013, 8, e70135.

[193] Li, Y.; Zhao, S.; Zhang, W.; Zhao, P.; He, B.; Wu, N.; Han, P. Epigallocatechin-3-O-gallate (EGCG) attenuates FFAs-induced peripheral insulin resistance through AMPK pathway and insulin signaling pathway in vivo. Diabetes Res. Clin. Pract., 2011, 93, $205-$ 214.

[194] Cai, E.P.; Lin, J.K. Epigallocatechin gallate (EGCG) and rutin suppress the glucotoxicity through activating IRS2 and AMPK signaling in rat pancreatic beta cells. J. Agric. Food Chem., 2009, 57, 9817-9827.

[195] Murase, T.; Misawa, K.; Haramizu, S.; Hase, T. Catechin-induced activation of the LKB1/AMP-activated protein kinase pathway. Biochem. Pharmacol., 2009, 78, 78-84.

[196] Collins, Q.F.; Liu, H.Y.; Pi, J.; Liu, Z.; Quon, M.J.; Cao, W. Epigallocatechin-3-gallate (EGCG), a green tea polyphenol, suppresses hepatic gluconeogenesis through 5'-AMP-activated protein kinase. J. Biol. Chem., 2007, 282, 30143-30149.

[197] Lin, C.L.; Huang, H.C.; Lin, J.K. Theaflavins attenuate hepatic lipid accumulation through activating AMPK in human HepG2 cells. J. Lipid Res., 2007, 48, 2334-2343.

[198] Zygmunt, K.; Faubert, B.; MacNeil, J.; Tsiani, E. Naringenin, a citrus flavonoid, increases muscle cell glucose uptake via AMPK. Biochem. Biophys. Res. Commun., 2010, 398, 178-183.

[199] Lei, H.; Lu, F.; Dong, H.; Xu, L.; Wang, J.; Zhao, Y.; Huang, Z. Genistein reverses free fatty acid-induced insulin resistance in HepG2 hepatocytes through targeting JNK. J. Huazhong Univ. Sci. Technol. Med. Sci., 2011, 31, 185-189.

[200] Cho, K.W.; Lee, O.H.; Banz, W.J.; Moustaid-Moussa, N.; Shay, N.F.; Kim, Y.C. Daidzein and the daidzein metabolite, equol, enhance adipocyte differentiation and PPARgamma transcriptional activity. J. Nutr. Biochem., 2009, 21, 841-847.

[201] Tsai, H.Y.; Wu, L.Y.; Hwang, L.S. Effect of a proanthocyanidinrich extract from longan flower on markers of metabolic syndrome in fructose-fed rats. J. Agric. Food Chem., 2008, 56, 11018-11024.

[202] Lee, Y.M.; Lee, J.O.; Jung, J.H.; Kim, J.H.; Park, S.H.; Park, J.M.; Kim, E.K.; Suh, P.G.; Kim, H.S. Retinoic acid leads to cytoskeletal rearrangement through AMPK-Rac1 and stimulates glucose uptake through AMPK-p38 MAPK in skeletal muscle cells. J. Biol. Chem., 2008, 283, 33969-33974.

[203] Figueras, M.; Olivan, M.; Busquets, S.; López-Soriano, F.J.; Argilés, J.M. Effects of eicosapentaenoic acid (EPA) treatment on insulin sensitivity in an animal model of diabetes: improvement of the inflammatory status. Obesity (Silver Spring), 2010, 19, 362369.

[204] Na, L.X.; Zhang, Y.L.; Li, Y.; Liu, L.Y.; Li, R.; Kong, T.; Sun, C.H. Curcumin improves insulin resistance in skeletal muscle of rats. Nutr. Metab. Cardiovasc. Dis., 2010, 21, 526-533.

[205] Park, C.E.; Kim, M.J.; Lee, J.H.; Min, B.I.; Bae, H.; Choe, W.; Kim, S.S.; Ha, J. Resveratrol stimulates glucose transport in $\mathrm{C} 2 \mathrm{C} 12$ myotubes by activating AMP-activated protein kinase. Exp. Mol. Med., 2007, 39, 222-229. 
[206] Lee, E.S.; Uhm, K.O.; Lee, Y.M.; Han, M.; Lee, M.; Park, J.M.; Suh, P.G.; Park, S.H.; Kim, H.S. CAPE (caffeic acid phenethyl ester) stimulates glucose uptake through AMPK (AMP-activated protein kinase) activation in skeletal muscle cells. Biochem. Biophys. Res. Commun., 2007, 361, 854-858.

[207] Lee, Y.S.; Kim, W.S.; Kim, K.H.; Yoon, M.J.; Cho, H.J.; Shen, Y.; Ye, J.M.; Lee, C.H.; Oh, W.K.; Kim, C.T.; Hohnen-Behrens, C.; Gosby, A.; Kraegen, E.W.; James, D.E.; Kim, J.B. Berberine, a natural plant product, activates AMP-activated protein kinase with beneficial metabolic effects in diabetic and insulin-resistant states. Diabetes, 2006, 55, 2256-2264.

[208] Turner, N.; Li, J.Y.; Gosby, A.; To, S.W.; Cheng, Z.; Miyoshi, H.; Taketo, M.M.; Cooney, G.J.; Kraegen, E.W.; James, D.E.; Hu, L.H.; Li, J.; Ye, J.M. Berberine and its more biologically available derivative, dihydroberberine, inhibit mitochondrial respiratory complex I: a mechanism for the action of berberine to activate AMP-activated protein kinase and improve insulin action. Diabetes, 2008, 57, 1414-1418.

[209] Liu, G.; Grifman, M.; Macdonald, J.; Moller, P.; Wong-Staal, F.; Li, Q.X. Isoginkgetin enhances adiponectin secretion from differentiated adiposarcoma cells via a novel pathway involving AMPactivated protein kinase. J. Endocrinol., 2007, 194, 569-578.

[210] Mooney, M.H.; Fogarty, S.; Stevenson, C.; Gallagher, A.M.; Palit, P.; Hawley, S.A.; Hardie, D.G.; Coxon, G.D.; Waigh, R.D.; Tate, R.J.; Harvey, A.L.; Furman, B.L. Mechanisms underlying the metabolic actions of galegine that contribute to weight loss in mice. Br. J. Pharmacol., 2008, 153, 1669-1677.

[211] Kameji, H.; Mochizuki, K.; Miyoshi, N.; Goda, T. $\hat{\mathrm{I}}^{2}$-Carotene accumulation in 3T3-L1 adipocytes inhibits the elevation of reactive oxygen species and the suppression of genes related to insulin sensitivity induced by tumor necrosis factor- $\alpha$. Nutrition, 2010, 26, 1151-1156.

[212] Furusho, T.; Kataoka, E.; Yasuhara, T.; Wada, M.; Innami, S. Administration of beta-carotene suppresses lipid peroxidation in tissues and improves the glucose tolerance ability of streptozotocininduced diabetic rats. Int. J. Vitam. Nutr. Res., 2002, 72, 71-76.

[213] Kappel, V.D.; Cazarolli, L.H.; Pereira, D.F.; Postal, B.G.; Zamoner, A.; Reginatto, F.H.; Silva, F.R. Involvement of GLUT-4 in the stimulatory effect of rutin on glucose uptake in rat soleus muscle. J. Pharm. Pharmacol., 2013, 65, 1179-1186.

[214] Zanatta, L.; Rosso, A.; Folador, P.; Figueiredo, M.S.; Pizzolatti, M.G.; Leite, L.D.; Silva, F.R. Insulinomimetic effect of kaempferol 3-neohesperidoside on the rat soleus muscle. J. Nat. Prod., 2008, $71,532-535$

[215] Tzeng, Y.M.; Chen, K.; Rao, Y.K.; Lee, M.J. Kaempferitrin activates the insulin signaling pathway and stimulates secretion of adiponectin in 3T3-L1 adipocytes. Eur. J. Pharmacol., 2009, 607, 2734.

[216] Li, Y.; Tran, V.H.; Koolaji, N.; Duke, C.; Roufogalis, B.D. (S)-[6]Gingerol enhances glucose uptake in L6 myotubes by activation of AMPK in response to $[\mathrm{Ca} 2+]$ i. J. Pharm. Pharm. Sci., 2013, 16, 304-312.

[217] Liu, J.; Zhang, J.F.; Lu, J.Z.; Zhang, D.L.; Li, K.; Su, K.; Wang, J.; Zhang, Y.M.; Wang, N.; Yang, S.T.; Bu, L.; Ou-Yang, J.P. Astragalus polysaccharide stimulates glucose uptake in L6 myotubes through AMPK activation and AS160/TBC1D4 phosphorylation. Acta Pharmacol. Sin., 2012, 34, 137-145.

[218] Minakawa, M.; Miura, Y.; Yagasaki, K. Piceatannol, a resveratrol derivative, promotes glucose uptake through glucose transporter 4 translocation to plasma membrane in L6 myocytes and suppresses blood glucose levels in type 2 diabetic model $\mathrm{db} / \mathrm{db}$ mice. Biochem. Biophys. Res. Commun., 2012, 422, 469-475.

[219] Mohankumar, S.K.; Taylor, C.G.; Siemens, L.; Zahradka, P. Activation of phosphatidylinositol-3 kinase, AMP-activated kinase and Akt substrate-160 kDa by trans-10, cis-12 conjugated linoleic acid mediates skeletal muscle glucose uptake. J. Nutr. Biochem., 2012, 24, 445-456.

[220] Kritchevsky, D.; Antimutagenic and some other effects of conjugated linoleic acid. Br. J. Nutr., 2000, 83, 459-465.

[221] Kim, M.S.; Hur, H.J.; Kwon, D.Y.; Hwang, J.T. Tangeretin stimulates glucose uptake via regulation of AMPK signaling pathways in $\mathrm{C} 2 \mathrm{C} 12$ myotubes and improves glucose tolerance in high-fat dietinduced obese mice. Mol. Cell. Endocrinol., 2012, 358, 127-134.

[222] Hsu, W.H.; Chen, T.H.; Lee, B.H.; Hsu, Y.W.; Pan, T.M. Monascin and ankaflavin act as natural AMPK activators with PPAR $\alpha$ agonist activity to down-regulate nonalcoholic steatohepatitis in high-fat diet-fed C57BL/6 mice. Food Chem. Toxicol., 2013, 64, 94-103.

[223] Zhang, F.; Sun, C.; Wu, J.; He, C.; Ge, X.; Huang, W.; Zou, Y.; Chen, X.; Qi, W.; Zhai, Q. Combretastatin A-4 activates AMPactivated protein kinase and improves glucose metabolism in $\mathrm{db} / \mathrm{db}$ mice. Pharmacol. Res., 2008, 57, 318-323.

[224] Kim, S.H.; Hwang, J.T.; Park, H.S.; Kwon, D.Y.; Kim, M.S. Capsaicin stimulates glucose uptake in $\mathrm{C} 2 \mathrm{C} 12$ muscle cells via the reactive oxygen species (ROS)/AMPK/p38 MAPK pathway. Biochem. Biophys. Res. Commun., 2013, 439, 66-70.

[225] Hwang, S.L.; Yang, B.K.; Lee, J.Y.; Kim, J.H.; Kim, B.D.; Kim, B.H.; Suh, K.H.; Kim, D.Y.; Kim, D.Y.; Kim, M.S.; Song, H.; Park, B.S.; Huh, T.L. Isodihydrocapsiate stimulates plasma glucose uptake by activation of AMP-activated protein kinase. Biochem. Biophys. Res. Commun., 2008, 371, 289-293.

[226] Hwang, S.L.; Kim, H.N.; Jung, H.H.; Kim, J.E.; Choi, D.K.; Hur, J.M.; Lee, J.Y.; Song, H.; Song, K.S.; Huh, T.L. Beneficial effects of beta-sitosterol on glucose and lipid metabolism in L6 myotube cells are mediated by AMP-activated protein kinase. Biochem. Biophys. Res. Commun., 2008, 377, 1253-1258.

[227] Li, H.B.; Ge, Y.K.; Zheng, X.X.; Zhang, L. Salidroside stimulated glucose uptake in skeletal muscle cells by activating AMPactivated protein kinase. Eur. J. Pharmacol., 2008, 588, 165-169.

[228] Nguyen, P.H.; Gauhar, R.; Hwang, S.L.; Dao, T.T.; Park, D.C.; Kim, J.E.; Song, H.; Huh, T.L.; Oh, W.K. New dammarane-type glucosides as potential activators of AMP-activated protein kinase (AMPK) from Gynostemma pentaphyllum. Bioorg. Med. Chem., 2011, 19, 6254-6260.

[229] Yoon, S.A.; Kang, S.I.; Shin, H.S.; Kang, S.W.; Kim, J.H.; Ko, H.C.; Kim, S.J. p-Coumaric acid modulates glucose and lipid metabolism via AMP-activated protein kinase in L6 skeletal muscle cells. Biochem. Biophys. Res. Commun., 2013, 432, 553-557.

[230] Huang, S.L.; Yu, R.T.; Gong, J.; Feng, Y.; Dai, Y.L.; Hu, F.; Hu, Y.H.; Tao, Y.D.; Leng, Y. Arctigenin, a natural compound, activates AMP-activated protein kinase via inhibition of mitochondria complex I and ameliorates metabolic disorders in ob/ob mice. Diabetologia, 2011, 55, 1469-1481.

[231] Ong, K.W.; Hsu, A.; Tan, B.K. Chlorogenic acid stimulates glucose transport in skeletal muscle via AMPK activation: a contributor to the beneficial effects of coffee on diabetes. PLOS ONE, 2012, 7, e32718.

[232] Hawley, S.A.; Fullerton, M.D.; Ross, F.A.; Schertzer, J.D.; Chevtzoff, C.; Walker, K.J.; Peggie, M.W.; Zibrova, D.; Green, K.A.; Mustard, K.J.; Kemp, B.E.; Sakamoto, K.; Steinberg, G.R.; Hardie, D.G. The ancient drug salicylate directly activates AMP-activated protein kinase. Science, 2012, 336, 918-922.

[233] Yuan, M.; Konstantopoulos, N.; Lee, J.; Hansen, L.; Li, Z.W.; Karin, M.; Shoelson, S.E. Reversal of obesity- and diet-induced insulin resistance with salicylates or targeted disruption of Ikkbeta. Science, 2001, 293, 1673-1677.

[234] Shen, Y.; Honma, N.; Kobayashi, K.; Jia, L.N.; Hosono, T.; Shindo, K.; Ariga, T.; Seki, T. Cinnamon extract enhances glucose uptake in 3T3-L1 adipocytes and $\mathrm{C} 2 \mathrm{C} 12$ myocytes by inducing LKB1-AMP-activated protein kinase signaling. PLoS ONE, 2014, 9, e87894.

[235] Lee, W.H.; Lin, R.J.; Lin, S.Y.; Chen, Y.C.; Lin, H.M.; Liang, Y.C. Osthole enhances glucose uptake through activation of AMPactivated protein kinase in skeletal muscle cells. J. Agric. Food Chem., 2011, 59, 12874-12881.

[236] Tamrakar, A.K.; Jaiswal, N.; Yadav, P.P.; Maurya, R.; Srivastava, A.K. Pongamol from Pongamia pinnata stimulates glucose uptake by increasing surface GLUT4 level in skeletal muscle cells. Mol. Cell. Endocrinol., 2011, 339, 98-104.

[237] Jaiswal, N.; Yadav, P.P.; Maurya, R.; Srivastava, A.K.; Tamrakar, A.K. Karanjin from Pongamia pinnata induces GLUT4 translocation in skeletal muscle cells in a phosphatidylinositol-3-kinaseindependent manner. Eur. J. Pharmacol., 2011, 670, 22-28.

[238] Huang, Y.C.; Chang, W.L.; Huang, S.F.; Lin, C.Y.; Lin, H.C.; Chang, T.C. Pachymic acid stimulates glucose uptake through enhanced GLUT4 expression and translocation. Eur. J. Pharmacol., 2010, 648, 39-49.

[239] Prasad, C.N.; Anjana, T.; Banerji, A.; Gopalakrishnapillai, A. Gallic acid induces GLUT4 translocation and glucose uptake activity in 3T3-L1 cells. FEBS Lett., 2009, 584, 531-536. 
[240] Jaiswal, N.; Maurya, C.K.; Venkateswarlu, K.; Sukanya, P.; Srivastava, A.K.; Narender, T.; Tamrakar, A.K. 4-Hydroxyisoleucine stimulates glucose uptake by increasing surface GLUT4 level in skeletal muscle cells via phosphatidylinositol-3-kinase-dependent pathway. Eur. J. Nutr., 2012, 51, 893-898.

[241] Prasad, J.; Maurya, C.K.; Pandey, J.; Jaiswal, N.; Madhur, G.; Srivastava, A.K.; Narender, T.; Tamrakar, A.K. Diastereomeric mixture of calophyllic acid and isocalophyllic acid stimulates glucose uptake in skeletal muscle cells: involvement of PI-3-kinaseand ERK1/2-dependent pathways. Mol. Cell. Endocrinol., 2013, $370,11-19$.

[242] Naresh, G.; Jaiswal, N.; Sukanya, P.; Srivastava, A.K.; Tamrakar, A.K.; Narender, T. Glucose uptake stimulatory effect of 4hydroxypipecolic acid by increased GLUT 4 translocation in skeletal muscle cells. Bioorg. Med. Chem. Lett., 2012, 22, 5648-5651.

[243] Hwang, S.L.; Chang, H.W.; Lee, I.K.; Yang, B.K.; Magae, J.; Chang, Y.C. Ascofuranone prevents ER stress-induced insulin resistance via activation of AMP-activated protein kinase in L6 myotube cells. Biochem. Biophys. Res. Commun., 2010, 396, 967-972.

[244] Hwang, S.L.; Yang, J.H.; Jeong, Y.T.; Kim, Y.D.; Li, X.; Lu, Y.; Chang, Y.C.; Son, K.H.; Chang, H.W. Tanshinone IIA improves endoplasmic reticulum stress-induced insulin resistance through AMP-activated protein kinase. Biochem. Biophys. Res. Commun., 2012, 430, 1246-1252.

[245] Hwang, S.L.; Jeong, Y.T.; Hye Yang, J.; Li, X.; Lu, Y.; Son, J.K.; Chang, H.W. Pinusolide improves high glucose-induced insulin resistance via activation of AMP-activated protein kinase. Biochem. Biophys. Res. Commun., 2013, 437, 374-379.

[246] Qiu, J.; Maekawa, K.; Kitamura, Y.; Miyata, Y.; Tanaka, K.; Tanaka, T.; Soga, M.; Tsuda, T.; Matsui, T. Stimulation of glucose uptake by theasinensins through the AMP-activated protein kinase pathway in rat skeletal muscle cells. Biochem. Pharmacol., 2013, 87, 344-351.

[247] Lee, S.H.; Kang, S.M.; Ko, S.C.; Lee, D.H.; Jeon, Y.J. Octaphlorethol A, a novel phenolic compound isolated from a brown alga, Ishige foliacea, increases glucose transporter 4-mediated glucose uptake in skeletal muscle cells. Biochem. Biophys. Res. Commun., 2012, 420, 576-581.

[248] Öberg, A.I.; Yassin, K.; Csikasz, R.I.; Dehvari, N.; Shabalina, I.G.; Hutchinson, D.S.; Wilcke, M.; Östenson, C.G.; Bengtsson, T. Shikonin increases glucose uptake in skeletal muscle cells and improves plasma glucose levels in diabetic Goto-Kakizaki rats. PLoS ONE, 2011, 6, e22510.

[249] Jia, Y.; Kim, J.Y.; Jun, H.J.; Kim, S.J.; Lee, J.H.; Hoang, M.H.; Hwang, K.Y.; Um, S.J.; Chang, H.I.; Lee, S.J. The natural carotenoid astaxanthin, a PPAR- $\alpha$ agonist and PPAR- $\gamma$ antagonist, reduces hepatic lipid accumulation by rewiring the transcriptome in lipid-loaded hepatocytes. Mol. Nutr. Food Res., 2012, 56, 878-888.

[250] Jia, Y.; Bhuiyan, M.J.; Jun, H.J.; Lee, J.H.; Hoang, M.H.; Lee, H.J.; Kim, N.; Lee, D.; Hwang, K.Y.; Hwang, B.Y.; Choi, D.W.; Lee, S.J. Ursolic acid is a PPAR- $\alpha$ agonist that regulates hepatic lipid metabolism. Bioorg. Med. Chem. Lett., 2011, 21, 5876-5880.

[251] Kuroyanagi, K.; Kang, M.S.; Goto, T.; Hirai, S.; Ohyama, K.; Kusudo, T.; Yu, R.; Yano, M.; Sasaki, T.; Takahashi, N.; Kawada, T. Citrus auraptene acts as an agonist for PPARs and enhances adiponectin production and MCP-1 reduction in 3T3-L1 adipocytes. Biochem. Biophys. Res. Commun., 2007, 366, 219-225.

[252] Goto, T.; Takahashi, N.; Kato, S.; Egawa, K.; Ebisu, S.; Moriyama, T.; Fushiki, T.; Kawada, T. Phytol directly activates peroxisome proliferator-activated receptor alpha (PPARalpha) and regulates gene expression involved in lipid metabolism in PPARalphaexpressing HepG2 hepatocytes. Biochem. Biophys. Res. Commun., 2005, 337, 440-445.

[253] Weidner, C.; de Groot, J.C.; Prasad, A.; Freiwald, A.; Quedenau, C.; Kliem, M.; Witzke, A.; Kodelja, V.; Han, C.T.; Giegold, S.; Baumann, M.; Klebl, B.; Siems, K.; Müller-Kuhrt, L.; Schürmann, A.; Schüler, R.; Pfeiffer, A.F.; Schroeder, F.C.; Büssow, K.; Sauer, S. Amorfrutins are potent antidiabetic dietary natural products. Proc. Natl. Acad. Sci. U.S.A., 2012, 109, 7257-7262.

[254] Kim, S.N.; Choi, H.Y.; Lee, W.; Park, G.M.; Shin, W.S.; Kim, Y.K. Sargaquinoic acid and sargahydroquinoic acid from Sargassum yezoense stimulate adipocyte differentiation through PPARalpha/gamma activation in 3T3-L1 cells. FEBS Lett., 2008, 582, 3465-3472.
[255] Zheng, W.; Feng, X.; Qiu, L.; Pan, Z.; Wang, R.; Lin, S.; Hou, D.; Jin, L.; Li, Y. Identification of the antibiotic ionomycin as an unexpected peroxisome proliferator-activated receptor $\gamma(\operatorname{PPAR} \gamma)$ ligand with a unique binding mode and effective glucose-lowering activity in a mouse model of diabetes. Diabetologia, 2012, 56, 401-411.

[256] Kim, H.; Chin, J.; Choi, H.; Baek, K.; Lee, T.G.; Park, S.E.; Wang, W.; Hahn, D.; Yang, I.; Lee, J.; Mun, B.; Ekins, M.; Nam, S.J.; Kang, H. Phosphoiodyns A and B, unique phosphorus-containing iodinated polyacetylenes from a Korean sponge Placospongia sp. Org. Lett., 2012, 15, 100-103.

[257] Li, J.L.; Xiao, B.; Park, M.; Yoo, E.S.; Shin, S.; Hong, J.; Chung, H.Y.; Kim, H.S.; Jung, J.H. PPAR- $\gamma$ agonistic metabolites from the ascidian Herdmania momus. J. Nat. Prod., 2012, 75, 2082-2087.

[258] Festa, C.; Lauro, G.; De Marino, S.; D'Auria, M.V.; Monti, M.C.; Casapullo, A.; D'Amore, C.; Renga, B.; Mencarelli, A.; Petek, S.; Bifulco, G.; Fiorucci, S.; Zampella, A. Plakilactones from the marine sponge Plakinastrella mamillaris. Discovery of a new class of marine ligands of peroxisome proliferator-activated receptor $\gamma . J$. Med. Chem., 2012, 55, 8303-8317.

[259] Mora, F.D.; Jones, D.K.; Desai, P.V.; Patny, A.; Avery, M.A.; Feller, D.R.; Smillie, T.; Zhou, Y.D.; Nagle, D.G. Bioassay for the identification of natural product-based activators of peroxisome proliferator-activated receptor-gamma (PPARgamma): the marine sponge metabolite psammaplin A activates PPARgamma and induces apoptosis in human breast tumor cells. J. Nat. Prod., 2006, 69, 547-552.

[260] Takahashi, N.; Goto, T.; Taimatsu, A.; Egawa, K.; Katoh, S.; Kusudo, T.; Sakamoto, T.; Ohyane, C.; Lee, J.Y.; Kim, Y.I.; Uemura, T.; Hirai, S.; Kawada, T. Bixin regulates mRNA expression involved in adipogenesis and enhances insulin sensitivity in 3T3-L1 adipocytes through PPARgamma activation. Biochem. Biophys. Res. Commun., 2009, 390, 1372-1376.

[261] Han, K.L.; Jung, M.H.; Sohn, J.H.; Hwang, J.K. Ginsenoside 20Sprotopanaxatriol (PPT) activates peroxisome proliferator-activated receptor gamma (PPARgamma) in 3T3-L1 adipocytes. Biol. Pharm. Bull., 2006, 29, 110-113.

[262] Wang, K.C.; Tsai, C.P.; Lee, C.L.; Chen, S.Y.; Lin, G.J.; Yen, M.H.; Sytwu, H.K.; Chen, S.J. $\alpha$-Lipoic acid enhances endogenous peroxisome-proliferator-activated receptor- $\gamma$ to ameliorate experimental autoimmune encephalomyelitis in mice. Clin. Sci., 2013, 125, 329-340.

[263] Xiao, B.; Su, M.; Kim, E.L.; Hong, J.; Chung, H.Y.; Kim, H.S.; Yin, J.; Jung, J.H. Synthesis of PPAR- $\gamma$ activators inspired by the marine natural product, paecilocin A. Mar. Drugs, 2014, 12, 926939.

[264] Atanasov, A.G.; Wang, J.N.; Gu, S.P.; Bu, J.; Kramer, M.P.; Baumgartner, L.; Fakhrudin, N.; Ladurner, A.; Malainer, C.; Vuorinen, A.; Noha, S.M.; Schwaiger, S.; Rollinger, J.M.; Schuster, D.; Stuppner, H.; Dirsch, V.M.; Heiss, E.H. Honokiol: a nonadipogenic PPAR $\gamma$ agonist from nature. Biochim. Biophys. Acta, 2013, 1830, 4813-4819.

[265] Choi, S.S.; Cha, B.Y.; Lee, Y.S.; Yonezawa, T.; Teruya, T.; Nagai, K.; Woo, J.T. Magnolol enhances adipocyte differentiation and glucose uptake in 3T3-L1 cells. Life Sci., 2009, 84, 908-914.

[266] Yang, Y.; Shang, W.; Zhou, L.; Jiang, B.; Jin, H.; Chen, M. Emodin with PPARgamma ligand-binding activity promotes adipocyte differentiation and increases glucose uptake in 3T3-Ll cells. Biochem. Biophys. Res. Commun., 2006, 353, 225-230.

[267] Fang, X.K.; Gao, J.; Zhu, D.N. Kaempferol and quercetin isolated from Euonymus alatus improve glucose uptake of 3T3-L1 cells without adipogenesis activity. Life Sci., 2008, 82, 615-622.

[268] Choi, S.S.; Cha, B.Y.; Iida, K.; Lee, Y.S.; Yonezawa, T.; Teruya, T.; Nagai, K.; Woo, J.T. Artepillin C, as a PPAR $\gamma$ ligand, enhances adipocyte differentiation and glucose uptake in 3T3-L1 cells. Biochem. Pharmacol., 2011, 81, 925-933.

[269] Xu, H.E.; Lambert, M.H.; Montana, V.G.; Parks, D.J.; Blanchard, S.G.; Brown, P.J.; Sternbach, D.D.; Lehmann, J.M.; Wisely, G.B.; Willson, T.M.; Kliewer, S.A.; Milburn, M.V. Molecular recognition of fatty acids by peroxisome proliferator-activated receptors. Mol. Cell., 1999, 3, 397-403.

[270] Lee, B.H.; Hsu, W.H.; Chang, Y.Y.; Kuo, H.F.; Hsu, Y.W.; Pan, T.M. Ankaflavin: a natural novel PPAR $\gamma$ agonist upregulates Nrf2 to attenuate methylglyoxal-induced diabetes in vivo. Free Radic. Biol. Med., 2012, 53, 2008-2016. 
[271] Lee, W.; Ham, J.; Kwon, H.C.; Kim, Y.K.; Kim, S.N. Anti-diabetic effect of amorphastilbol through PPAR $\alpha / \gamma$ dual activation in $\mathrm{db} / \mathrm{db}$ mice. Biochem. Biophys. Res. Commun., 2013, 432, 73-79.

[272] Ding, L.; Jin, D.; Chen, X. Luteolin enhances insulin sensitivity via activation of PPAR $\gamma$ transcriptional activity in adipocytes. J. Nutr. Biochem., 2009, 21, 941-947.

[273] Shin, D.W.; Kim, S.N.; Lee, S.M.; Lee, W.; Song, M.J.; Park, S.M.; Lee, T.R.; Baik, J.H.; Kim, H.K.; Hong, J.H.; Noh, M. (-)Catechin promotes adipocyte differentiation in human bone marrow mesenchymal stem cells through PPAR gamma transactivation. Biochem. Pharmacol., 2008, 77, 125-133.

[274] Matin, A.; Doddareddy, M.R.; Gavande, N.; Nammi, S.; Groundwater, P.W.; Roubin, R.H.; Hibbs, D.E. The discovery of novel isoflavone pan peroxisome proliferator-activated receptor agonists. Bioorg. Med. Chem., 2012, 21, 766-778.

[275] Lee, J.H.; Jun, H.J.; Hoang, M.H.; Jia, Y.; Han, X.H.; Lee, D.H.; Lee, H.J.; Hwang, B.Y.; Lee, S.J. Catalposide is a natural agonistic ligand of peroxisome proliferator-activated receptor- $\alpha$. Biochem. Biophys. Res. Commun., 2012, 422, 568-572.

[276] Lee, I.K.; Lee, J.H.; Yun, B.S. Polychlorinated compounds with PPAR-gamma agonistic effect from the medicinal fungus Phellinus ribis. Bioorg. Med. Chem. Lett., 2008, 18, 4566-4568.

[277] Salam, N.K.; Huang, T.H.; Kota, B.P.; Kim, M.S.; Li, Y.; Hibbs, D.E. Novel PPAR-gamma agonists identified from a natural product library: a virtual screening, induced-fit docking and biological assay study. Chem. Biol. Drug Des., 2007, 71, 57-70. 